

PM-1 31\%2" $\times 4$ " PHOTOGRAPHIC MICROCOPY TARGET NBS 1010a ANSI/ISO \#2 EOUIVALENT

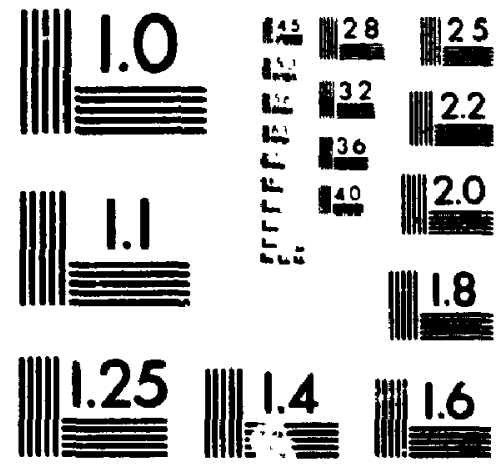

PRECISIONEM RE OLUTION TARGETS 
National Library

of Canada

Acquisitions and

Bibliographic Services Branch

395 Wellinglon Street

Onawa. Ontano

K1A ON4
Biblıotheque nationale

ou Canada

Direction des acquisitions ef des services bibliographiques

395. nue Wellingion

Otlawa (Onlario)

KIA ON4

NOTICE

AVIS

The quality of this microform is heavily dependent upon the quality of the original thesis submitted for microfilming. Every effort has been made to ensure the highest quality of reproduction possible.

If pages are missing, contact the university which granted the degree.

Some pages may have indistinct print especially if the original pages were typed with a poor typewriter ribbon or if the university sent us an inferior photocopy.
La qualité de cette microforme dépend grandement de la qualité de la thèse soumise au microfilmage. Nous avons tout fait pour assurer une qualité supérieure de reproduction.

S'il manque des pages, veuillez communiquer avec l'université qui a conféré le grade.

La qualité d'impression de certaines payes peut laisser à désirer, surtout si les pages originales ont été dactylographiées à l'aide d'un ruban usé ou si l'université nous a fait parvenir une photocopie de qualité inférieure.

La reproduction, même partielle, de cette microforme est soumise à la Loi canadienne sur le droit d'auteur, SRC 1970, c. C-30, et ses amendements subséquents.
Reproduction in full or in part of this microform is governed by the Canadian Copyright Act, R.S.C. 1970, c. C-30, and subsequent amendments. 


\title{
The Origins of Canadian Participation in the United Nations Operation in the Congo, 1960
}

\author{
by
}

Kevin A. Spooner, B.A.(Hons.), B.Ed.

$A$ thesis submitted to the Faculty of Graduate Studies and Research in partial fulfilment of the requirements for the degree of Master of Arts

\author{
Department of History \\ ('arleton University \\ Ottawa, Ontario \\ August, 1995
}

(c) Copyright, 1995

Kevin A. Spooner 
National Library

of Canada

Acquisitions and

Bibliographic Services Branch

395 Wellington Street

Ontawa. Ontario

KIA ON4
Bibliotheque nationale

du Canada

Direction des acquisitions et

des services bibliographiques

395. rue Wellington

Ontawa (Ontario)

K1A ON4 vour the vorie retwonce

Our tile Nore roterence
The author has granted an irrevocable non-exclusive licence allowing the National Library of Canada to reproduce, loan, distribute or sell copies of his/her thesis by any means and in any form or format, making this thesis available to interested persons.

The author retains ownership of the copyright in his/her thesis. Neither the thesis nor substantial extracts from it may be printed or otherwise reproduced without his/her permission.
L'auteur a accordé une licence irrévocable et non exclusive permettant à la Bibliothèque nationale du Canada de reproduire, prêter, distribuer ou vendre des copies de sa thèse de quelque manière et sous quelque forme que ce soit pour mettre des exemplaires de cette thèse à la disposition des personnes intéressées.

L'auteur conserve la propriété du droit d'auteur qui protège sa thèse. Ni la thèse ni des extraits substantiels de celle-ci ne doivent être imprimés ou autrement reproduits sans son autorisation.

ISBN $\quad 0-612-08929-0$ 
Dissertation Abstracts internationol is arranged by broad, general subject categories. Please select the one subject which most nearty describes it content of your dissertation Enter the corresponding four.digit cade in the spaces provided.

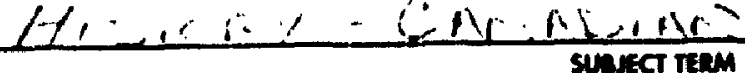

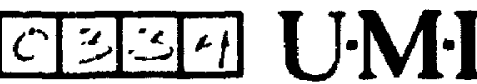

surect coos

\section{Subijact Cobegories}

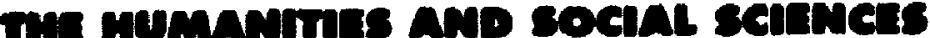

\begin{tabular}{|c|c|}
\hline 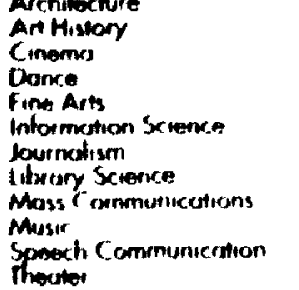 & $\begin{array}{l}0377 \\
0900 \\
0378 \\
0357 \\
0723 \\
0391 \\
0399 \\
0708 \\
0413 \\
0459 \\
0465\end{array}$ \\
\hline 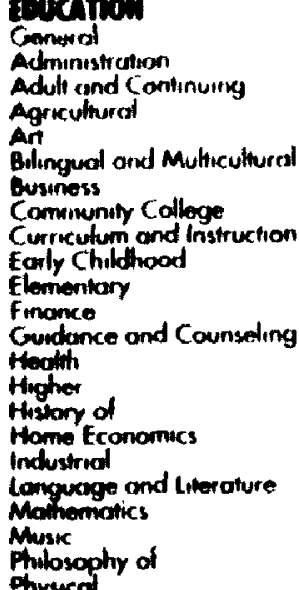 & $\begin{array}{l}0515 \\
0514 \\
0516 \\
0517 \\
0273 \\
0282 \\
0688 \\
0275 \\
0727 \\
0518 \\
0524 \\
0277 \\
0519 \\
0680 \\
0745 \\
0520 \\
0278 \\
0521 \\
0279 \\
0280 \\
0522\end{array}$ \\
\hline
\end{tabular}

Phrucet

$\begin{array}{ll}\text { Poychology } & 0525 \\ \text { Rexding } & 0535 \\ \text { Religious } & 0527 \\ \text { Sciances } & 0714 \\ \text { Socondery } & 0533 \\ \text { Socid Sciences } & 0534 \\ \text { Soxiology of } & 0340 \\ \text { Specicl } & 0529 \\ \text { Teocher Troining } & 0530 \\ \text { Techinoiogy } & 0710 \\ \text { Tests ond Meosurements } & 0288 \\ \text { Vocotional } & 0747\end{array}$

\section{umeunes, Lteratuar ano} incusnics

Lomgurage

Ancient

Linguistics

Modern

Linerofure

Classical

Comporative

Modieval

Modern

Africon

American

Aston

Conodian (English)

Conodian (French)

English

Germonic

Latin American

Middlie Eastern

Romance

Slavic and East European

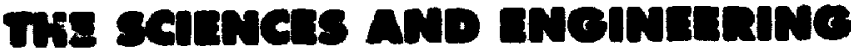



\begin{tabular}{|c|c|}
\hline $\begin{array}{l}\text { Geodesy } \\
\text { Geology } \\
\text { Geophysics } \\
\text { Hodrotogy } \\
\text { Mineralogy } \\
\text { Poloobotany } \\
\text { Paleovcology } \\
\text { Paleoniology } \\
\text { Poloozoology } \\
\text { Polynology } \\
\text { Physucal Geography } \\
\text { Physical Oceonography }\end{array}$ & $\begin{array}{l}0370 \\
0372 \\
0373 \\
0388 \\
0411 \\
0345 \\
0426 \\
0418 \\
0985 \\
0427 \\
0368 \\
0415\end{array}$ \\
\hline 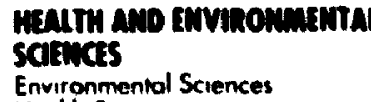 & 0768 \\
\hline 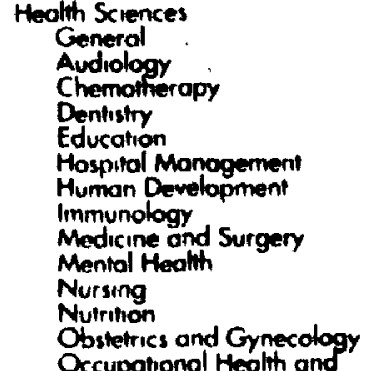 & $\begin{array}{l}0566 \\
0300 \\
0992 \\
0567 \\
0350 \\
0769 \\
0758 \\
0982 \\
0564 \\
0347 \\
0569 \\
0550 \\
0380\end{array}$ \\
\hline $\begin{array}{l}\text { Therapy } \\
\text { Ophiholmology } \\
\text { Pothology } \\
\text { Phormocology } \\
\text { Phormocy } \\
\text { Physical thercopy } \\
\text { Public Heolth } \\
\text { Radiology } \\
\text { Recreohon }\end{array}$ & $\begin{array}{l}119 \\
572 \\
382 \\
573 \\
574 \\
575\end{array}$ \\
\hline
\end{tabular}

Pmioserwy, neveion ano

\section{Tizolosy}

Philosophy

Religion

Biblical Studies

Blica

History of

Philosophy of

Theology

soant sasuds

Americon Studies

Anthropelogy

Archoeology

Cuthura!

Bustiness Administration

General.

Accounting

Bonking

Management

Monodion Studies

Economics

General

Agricultural

Commerce-Business

Finonce

Mistory

Theory

Folklore

Geogrophy

Gerontology

History

General
0422

0318

0321

0319

0320
0322

0469

0323

0324

$\checkmark 326$

0310

0272
0770

0454

0338

0501

0503
0505

0508

0509

0510

0511
0358

0366

0351

0578

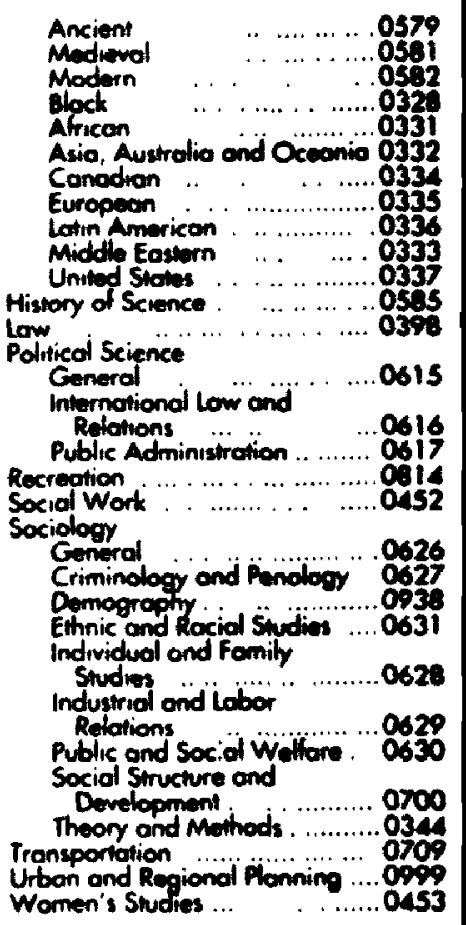

Enginearing

Generd

Aerospoce

Agriculturel

Biomedical.

Chomical

Civil

0465

Chemistry

Agenticuliural

Analytical

Biochiomisiny

Inorganic

Orgonic

Pharmacestical

Physical

Polymer

Numemotics

Physics

General

Acoustics

Astronomy and

Astrophysics

Alomic

Electronks ond Electricity

Elementon forticlas and

High Energr.

Fluid and Plasmo

Moleculor

Nucleor

Ophics

Rodiotion

Shatistics

Electronics ond Electiricol ....... 054

Hoot and Thermodymomics ..034

Hrdroulic

Morine

Moteriats Science .... ......... 079

Mochanied …................. 054

Motollurgy $\quad . . \ldots \ldots \ldots \ldots \ldots . . .6743$

Mining

Nucloor

Pockoging

Srutem and Municipol ....... ofs

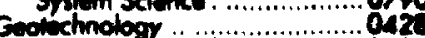

Operotions Rosometh ...............07\%

Plastres Technology . ...............079s

Taxtile Technoloy

21

\section{crrapeor}

\section{General}

0798

0609

Clinicol

Demelopmenial ....................\%820

Exporimental . ....................023

Indusuriol.

Perwonality.

Prychobioloog

Pirchometric:

soxid.
Arptind Sciences

Applied Muchonics 
The undersigned recommend to the Faculty of iraduate Studies and Research acceptance of the thesis

"THE ORIGINS OF CANADIAN PARTICIPATION IN THE UNITED NATIONS OPERATION IN THE CONGO, 1960"

submitted by

Kevin A. Spooner, B.A., B.Ed.,

in partial fulfilment of the requirements

for the degree of Master of Arts

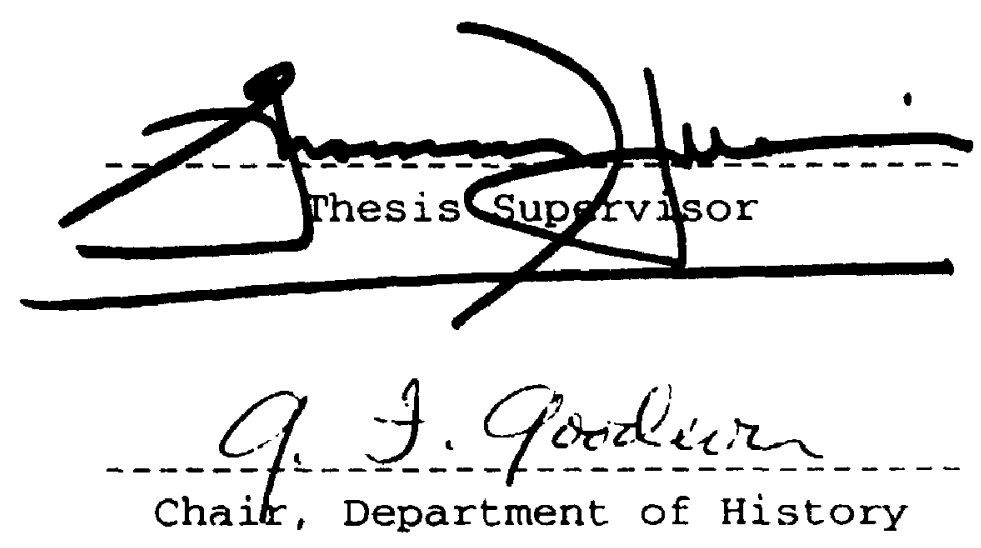

Carleton University

23 August 1995 


\begin{abstract}
$\underline{\text { Abstract }}$
This thesis examines the (anadian decision to participate in the United Nations (operation in the Congo (UNOC), which was established to restore law and order when the Congolese military mutinied after independence. It reviews Canadian relations with the Belgian (ongo prior to independence, but focuses on the three month period from July to September 1960. $I$,ittle has been written on the subject of Canadian participation in $\mathrm{UNC})$. Existing interpretations suggest that the government was reluctant to participate but was forced to succumb to public pressure to assist the UN. An assessment of the evidence, however, suggests that the Diefenbaker government did not reverse its policy. Rather, it gradually increased the level of ('anadian participation. Moreover, the Canadian commitment was not strengthened as a result of public pressure alone; (anadian officials also recognised that if the UN failed with UNC $K$, it could be irrevocably undermined and Africa could be further penetrated by communists.
\end{abstract}




\section{Acknowledgements}

In my efforts to complete this thesis, I have received a great de at help, from many people. I would like to thank (arleton University and the Department of National Defence for their generous financial assistance. Paulette Dozois, of the National Archives of (anada, and lisabel ( ampleell, of the Directorate of History-Department of National I lefence, both provided instrurnental assistance as I searched for primary sources. NIs. Joan White and P'rofessor D.L. McDowall, of the History Department at ('arleton, alwaly's ensured that the administrative details of my graduate studies were in order.

Throughout my years as a student, 1 have been fortunate to have had the advantage of several excellent teachers. Professor J. Jennings, l'rofessior J. Stubbs, Professor A.B. McKillop and Professor 1).l'. Be-rill e'ach taught me a great deal and have also given generously of their time when asked to write letters of reference on my behalf. I simply can not pay adequate tribute to the assistance and support I received from my thesis supervisor, l'rofensor Norman Hillmer. I have greatly benefited from his abilities as both a teacher and historian.

Work on my thesis, all too often, took away from time I would have preferred to spend with my two families. Thanks to Kenneth, (iloricl, I racy and Mrs. Cecilia Spooner and to Ramesh, Hansa, Krishan and Mrs. Maniben Mehta for their understanding. Most of all, 1 would like to thank my wife for all of her support during the past two years. Without Bina, this thesis could not have been completed.

Finally, I would like to dedicate this work to the memory of my late grandfather, Kenneth Arthur Spooner. It was he who instilled within me a true appreciation for teiling stories and arguing a point. I have yet to encounter anyone who can do these two things better than he could, and I fully expect that 1 never will. Thanks grandpa.

$$
\text { K.A.S. }
$$




\section{1 ble of Contents}

Page

Introduction 1

$\begin{array}{ll}\text { ('hapter 1: Prelude to Crisis } & 10\end{array}$

( hapter 2: The Canadian Response 43

('hapter 3: Operation Mallard: The Early Canadian 81 Contribution to UNOC

Conclusion

Appendix 1: UN resolutions applicable to UNOC (July - siptember, 1960)

Bibliography 


\section{Introduction}

(On June 30, 1960 the Belgian (ongo gained independence. It did so as African nationalism swept the continent and as Cold War tensions threatened to internationalise local conflicts. Unfortunately, the United Nations had failed to function as originally envisioned by those who drafted its charter in 1945; by 1960, for exampie, the provisions for collective security and sanctions had been used only once, in Korea. It was difficult for the Security Council to take concerted action because its permanent members each had the right of veto, and often disagreed with each other on substantive matters.

Peacekeeping emerged early in the post-war period as a tool for conflict resolution and as a means to compensate for the inability of the Sicurity Council to enforce firm and decisive solutions to international conflicts. By 1960, the UN had established two peace observation missions in the Middle East, and one along the border between India and lakistan. Moreover, the United Nations Emergency Force (UNEF) had been mounted to monitor peace between Israel and Egypt, following Nasser's nationalisation of the Suc\% Canal and the subsequent Israeli, British and French military intervention. Canada played a significant role in this early period of peacekeeping. Canadians served with all early UN peace missions and Lester Pearson received the Nobel prize for his diplomatic tour de force-the application of the peacekeeping concept to the Suez crisis, with the creation and implementation of UNEF.

The concept and practice of peacekeeping was therefore in development for some 13 years before the circumstances of the ('ongo's 


\section{Chapter 1 \\ Prelude to Crisis}

The Belgian connection with the Congo began in the late 1800s, when King Leopold II, the reigning monarch, hired the explorer Henry Stanley to establish trading posts in Central Africa. Stanley was successful in his mission, and a sphere of influence was established for Leopold. Britain, France, Italy, Germany, Portugal and the Netherlands all competed for African territories, but Leopold shrewdly played each Power against the others and in the end retained control over the Congo. In view of his humanitarian pronouncements on the region's economic development, Leopold's claim was officially recognised during the Berlin Conference of 1884-85. More to the point, he was willing to maintain the Congo as an African zone for free trade and this appealed to the economic interests of each of the European states. After intense lobbying by two of Leopold's aides, the Belgian parliament approved legislation that permitted Leopold to become sovereign of both Belgium and the Congo Independent State.13

Under Leopold, the Congo Independent State quickly became a hotbed of commercial activity and colonial exploitation. Huge tracts of land were granted to private companies, as a means of raising money. Railroad development was also encouraged through a system of land grants. Private enterprise also benefited from a state imposed labour tax that virtually forced the native Congolese to spend most of their time collecting rubber and ivory. The Anglo-Belgian-Indian Rubber Company was one of the largest commercial enterprises in the Congo, but Leopold's Domaine de la Couronne

13 David N. Cibbs, The Political Economy of Third World Intervention (Chicago: $U$ of (hicago P, 1991) 40-41 and Michel Struetens, The United Nations in the Congo or O.N.U.C. and International Politics (Brussels: Max Arnold Publisher, 1976) 17-18. 
(ongo all provide accounts of the crisis and the UN's response. I lecades later, a new generation of literature has emerged as authors reexamine the I Inited Nations Operation in the Congo. Stephen WVeissman's American lioreign Policy in the Congo 1960-1964. Madeleine Kalb's '1he (ongo (ables and I )avid Gibbs' The Political Eronomy of 'Third IVorld Intervention all address the issue of American involvement in the (ongo crisis. $A$ number of biographies of key individuals associated with UNC $X$ ' have also appeared: Brian Urquhart's Hammarskjold, ('arl von I lorn's Soldiering for l'eace, Rajeshwar Dayal's Mission for Hammarskjöld and Lo Katanga and lBack, by Conor Cruise O'Brien.5 Finally, there are some reference books which provide useful information about UNOC. 'These would include: Rosalyn Iliggins' United Nations Peacekeeping 1946-1967 1)ocuments and (ommentary vol. 3, R. Simmonds' Legal Problems Arising from the United Nations Military Operations in the Congo and The Blue I lelmets: a Review of United Nations: Peace-keeping published by the UN."

The real basis for this study was the primary material available at the

3 Alan P. Merriam, Congo: Background to Conflict (Illinois: Northwestern U I', 1961):

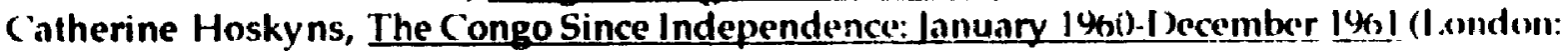
(xford U P, 1965); Lee Arthur Burns and Nina H leatheote, Peacekeeping by U.N. Iurces (London: Pall Mall Press, 1963); Ernest W. Lefever, Crisis in the C'ongo (Washington, 1 ). '.: I he Brookings Institution, 1965); J. King Gordon, the Uniled Nations in the Congo (C arnegice Endowment for International Peace, 1962).

+ Stephen R. Weissman, American Forcign Policy in the Congo 1960)-1964 (Ithaca: Cornell U P, 1974); Madeleine Kalb, The Congo Cables (New York: Macmillan l'ublishung, ' $1 .$, Inc., 1982); David N. Gibbs, The Political Economy of I hird World Intervention (C 'hicagu: l, ol ('hicago P, 1991).

5 Brian Urquhart, Hammarskjold (New York: Alfred $\wedge$. Knopf, 1972); Miy. (ien ( irl von Horn, Soldiering for Peace (London: Cassell, 1966); Rajeshwar Da, :1, Mission for Hammarskjold: the Congo Crisis (Princeton: P'rinceton U P', 1976); ('onor : 'ruise ()'Brien, lo Katanga and Back (New York: Grosset and Iunlap, 1962).

h Rosalyn Higgins, united Nations P'eacekeeping 1946-1967 1)ocuments and Commentary 4 vols. (Oxford: Oxford U 1', 1980); R. Simmonds, 1. sgal l'roblems Arising, Irom the Uniled Nations Operutions in the Congo (l'he Hague: Martinus Nijhoff, 1968); Uniled Nallon's, The Blue Helmets, 2nd ed. (New York: United Nalions I Jepartmant of P'ublic Inlormation, $1990)$. 
National Archives of ( anada and the I)irectorate of History at the 1)epartment of National Defence. The Government Archives Division contains a wealth of information on ('anadian-Belgian Congo relations, the initial days of the (ongo crisis and Canadian participation in UNCC. Documents from Irade and (ommerce (KC;20), the Department of National I)efence (RC;24), lixternal Affairs (RC;25) and the Cabinet (RG2) were all available for consultation. Very little difficulty was experienced in gaining access to government documents and files hitherto closed. Occasionally, an individual document was removed from a file to permit the remaining documents to be viewed. This was, however, rare. An exception to the relatively free access to documents was the file containing copies of the minutes of the United Nations Advisory Committee on the Congo, to which ( anada was permitted to send a representative. This file is closed, and is likely to remain so in the foreseeable future. (iven the scope of this thesis, it should be of little consequence. The Advisory Committee on the Congo did not meet until August 24th, and the majority of this study is devoted to the period trom the onset of the crisis to before this date.

Material administered by the Manuscript Division of the National Archives was quite often closed or unavailable for consultation. Open files from the Norman Robertson and Basil Robinson collections were consulted. Many more file:s were closed, including files from these two collections as Well as all pertinent files in the Howard Green collection. The finding aids for the I iefenbaker files revealed that there was likely to be very little within that collection on the congo. Thus, consultation of these papers, located at the University of Regina, was unwarranted. 'The views and actions of these key individuals were well documented in other collections. RC;25 contained an 
extensive number of documents that were reviewed by, and received comments from, Diefenbaker, Robinson and Robertson. Diefenbake'r's vie'ws: are also covered in his autobiography and the work done by Basil kobinson, Diefenbaker's World.

The primary and secondary sources were supplemented by a number of additional items that shed light on Canadian involvenent with the Helgian Congo and UNC $X$. Hansard provides a thorough account of public statements by both the Government and the (Opposition parties. $A$ number of articles on UNOC were found in the journal External Affairs. (ontemporary periodical literature also proved useful. Articles on C'anada, UNCX' and the ('ongo) appeared in the New York Times, Maclean's, and Saturday Night lihe Cilobo and Mail provided extensive coverage of relevant issues. I'wo other sources, the Commercial Intelligence Journal and Foreign Irade, provided detailed articles and statistics on Canada-Belgian ('ongo economic relations.

Within the limited historiography of ('anadian peacekeceping, two articles by J.L. Granatstein have raised a significant issue: the ('anadian motivation for peacekeeping. ${ }^{7}$ The aim of this thesis is to addre'ss this issue, specifically in relation to the United Nations ()peration in the (ongo. Werc there economic interests that motivated the government to become involved? David Gibbs, in assessing American policy in the (ongo, has argued that economic and business considerations, more than anything alse, determined the actions and policies of U.S. officials." Was the ('anadian government motivated to send peacekeepers to the (ongo out of foar that

7 J.L. Granatstein, "Canada and Peacekeeping: Myth and Reality," 'The ( allodtion Furum 54.263 (1974) and J.1. (Granatstein, "l'eacekeeping: I)id ( anada Make a I Iff(cronce! And What Difference Did Peacekeeping Make to Canada?" Making a I)iflerencene? lid. Iohnl lingll.,h and Norman Hillmer (Toronlo: I.ester P'ublishing limiled, 1992).

$\checkmark$ David N. Gibbs, The l'olitical ticonomy of Ihird World Intervention: Mine", Money, and U.S. Policy in the Congo ('rists (Chicago: U of ('htcago P, 1991 ). 
instability in the region would lead to communist intervention? Did public opinion at home, derived principally from pride in Canada's peacekeeping record, force the Diefenbaker government's hand? Was the UN in such dire need of peacekeepers that it was simply disinclined to accept 'no' for an answer?

While very little has been written on the subject of Canada's role in UNCX:, J.I. Granatstein and Fred Gaffen do provide brief accounts in their histories of ('anadian peacekeeping." Both authors argue that Diefenbaker was reluctant to send peacekeepers to the Congo until public opinion forced the government "to abandon its reluctance."11" Examination of the historical evidence shows that Diefenbaker was hesitant to commit combat forces to UNOC: because of the risks posed to 'white' peacekeepers, who would be expected to restore order in a predominantly 'black' society attempting to make the difficult transition from colony to nation. He was, however, never reluctant to provide less dangerous types of support for UNOC. In fact, during the last two weeks of July 1960, the Conservative government incrementally approved measures to support the UN's peacekeeping mission in the Congo, culminating in the dispatch of a Signals Squadron. Because the Signals personnel were not expected to play a combat role, it is inaccurate to suggest that their inclusion in UNOC constituted a change in the government's policy. Moreover, the decisions to gradually increase the level of Canadian participation in UNOC: was based, not exclusively on public pressure to

9 Fred Gaffen, In the Eye of the Storm: a History of Canadian Peacekeeping (Toronto: I Mneau and Wayne, 1987) and J.L. Granatstein, "Canada: Peacekeeper, A Survey of Canada's larticipation in Peacekeeping Operations," Peacekeeping: International Challenge and Canadian Response Ed. Alastair Taylor (Lindsay: Canadian Institute of Inlernational Affairs, 14(6).

10 J.L. Ciranatstein, "Canada: Peacekeeper, A Survey of Canada's Participation in l'eacekeeping (Operations," Peacekeeping: International Challenge and Canadian Response Ed. Alastair Iaylor (l.indsay: Canadian Instilute of International Affairs, 1968) 164. 
participate, but also on the premise that the UN itself could be irrevocably undermined if the organisation failed to restore peace to the ('ongo. The government also hoped that its support of $U N C X$ would prevent the further penetration of communism in Africa.

J.L. Granatstein warns of the danger in making peacekeeping decisions based on an irrational desire by the Canadian public to fulfil a partly selfassigned role as world peacemonger. He wrote:

... for too many Canadians peacekeeping has become a substitute for policy and thought. ... But let us, at the very least, retain and enhance our right to consider which PKOs we shall participate in, just as we have the right to consider which wars we shall fight. Governments, like individuals, are supposed to be capable of rational decision making. And automatic responses-whether "My country right or wrong" or "Send in the Canadian peacekeepers"-are no substitutes for thought."1

It is difficult to dispute the wisdom of Granatstein's argument. ('anada must retain its right at all times to determine when, and if, its armed forces will be used, particularly if the lives of military and civilian personnel may be placed at risk. Yet, the military's peacekeeping and technical training, combined with Canada's status as a middle power, has placed Canada within a group of nations that are often called upon to support UN peacekeeping activities, 12 Along with other nations such as Sweden, Ireland, Italy and India, ('anada is seen as a nation large enough to contribute armed forces with the requisite specialised training, and yet not so large that it is likely to be inherently

11 J.L Granatstein, "Peacekeeping: Did Canada Make a Difference? And What Difference Did Peacekeeping Make to Canada," Making a Difference? Eds. John Iinglish and Norman Hillmer (Toronto: Lester Publishing Limited, 1992): 234.

12 Canada is often seen by the international community as an especially suitable country to contribute forces because there seems to be the perception, or perhaps misperception. that Canada is neutral and without a colonial past. For example, the UN Secretary-(ieneral Dag Hammarskjöld is said to have perceived Canada as only, "marginally aligned." Moreover, Canada's contributions to British imperialism, including the British advance along the Nile 10 Khartoum and participation in the South African War are often forgotten. 
interested in the outcome of most conflicts.

It is imperative, as Ciranatstein suggests, to arrive at decisions by rational means. All too often emotions shape public perceptions, but the extent to which public pressure in turn influences the ultimate Canadian responses to UN requests is not at all clear. Public pressure is undoubtedly an important factor that every Prime Minister and Cabinet take into account as they discuss the provision of forces for peacekeeping missions. The political repercussions of either heavy Canadian casualties or the perception that Canada is not fulfilling its responsibilities and obligations are far too obvious for any politician to ignore or overlook. Nevertheless, as with writing on the Diefenbaker government and UNOC, the : Cicance of public pressure should not be overstated and the significance of other factors overlooked.

Chapter one, 'Prelude to Crisis,' traces trade and foreign relations between the two countries in the period leading to the mutiny of the Congolese army and the subsequent breakdown of civil order. It demonstrates that Canada was interested in the Belgian Congo, and was relatively well informed about this African colony. The development of a Canadian foreign policy towards Africa is also discussed. Were there clear economic, political or security issues involved in the government's decision that had roots in the pre-independence period? That is the central issue of this chapter.

'The Canadian Response,' chapter two, is a reconstruction of the key events of July, 1960 that ultimately resulted $\eta$ the Cabinet's Order-in-Council to establish the Canadian contingent of UNOC. The process by which a final decision was made, within the institutional structures of the Department of National Defence, the Department of External Affairs, and the Cabinet, will be described in detail. Connections with the historical context set out in chapter 
one will be explained, and the issues of self-interest and motivation will be assessed.

The final and third chapter, 'The Early Canadian contribution to UNOC, will review the early implementation of Canadian policy from July to the end of September, 1960. At that time, the Congo crisis took on new directions. General Joseph Mobutu succeeded in assuming effective control over the Congolese government and the UN General Assembly was called upon to consider the Congo situation as policy formulation in the Security Council reached a deadlock. During this period, Canadian troops were deployed and faced initial hostility from both the Congolese people and military. In this context, the implication of the linguistic and racial composition of the force will be discussed. 


\section{Chapter 1 \\ Prelude to Crisis}

The Belgian connection with the Congo began in the late 1800 s, when King leopold II, the reigning monarch, hired the explorer Henry Stanley to establish trading posts in Central Africa. Stanley was successful in his mission, and a sphere of influence was established for Leopold. Britain, France, Italy, Germany, Portugal and the Netherlands all competed for African territories, but Leopold shrewdly played each Power against the others and in the end retained control over the Congo. In view of his humanitarian pronouncements on the region's economic development, Leopold's claim was officially recognised during the Berlin Conference of 1884-85. More to the point, he was willing to maintain the Congo as an African zone for free trade and this appealed to the economic interests of each of the European states. After intense lobbying by two of Leopold's aides, the Belgian parliament approved legislation that permitted Leopold to become sovereign of both Belgium and the Congo Independent State.13

Under Leopold, the Congo Independent State quickly became a hotbed of commercial activity and colonial exploitation. Huge tracts of land were granted to private companies, as a means of raising money. Railroad development was also encouraged through a system of land grants. Private enterprise also benefited from a state imposed labour tax that virtually forced the native congolese to spend most of their time collecting rubber and ivory. The Anglo-Belgian-Indian Rubber Company was one of the largest commercial enterprises in the Congo, but Leopold's Domaine de la Couronne

1.3 David N. Gibbs, The Political Economy of Third World Intervention (Chicago: $U$ of (hicago P, 1991) 40-41 and Michel Struelens, The United Nations in the Congo or O.N.U.C. and International Polilics (Brussels: Max Arnold Publisher, 1976) 17-18. 
remained the largest concession. Covering an are : the size of Poland, this region served only to enrich the Belgian royal family.14

The region of Katanga was left largely unexplored until leopold began to fear that it might be annexed by the Britısh. To develop the province, he granted land and resource rights to private companies, as he had done in the rest of the colony, but in Katanga, this reciprocal relationship of development and exploitation reached new heights. In the early twentieth century, a number of companies were created to develop Katangan resources. Copper and diamonds were mined by the Union Minière du Haut Katanga and Ia Société Internationale Forestière at Minière du Congo (FORMINIERI:) respectively, and each of these major companies was owned in part by the Société Gézérale de Belgique, a company that was also closely linked to the royal family. In Katanga, more than in any other Congolese region, private enterprise played a dominant economic and administrative role. 15 This arrangement was a critical factor in the secession crisis that followed soon after independence.

By 1908, poor economic conditions meant that the Congo was not nearly as profitable as it had once been. There were also growing international protests, particularly in Great Britain, over the horrendous living conditions of the Congolese. Both these factors led Leopold to relinquish control of the Congo to the Belgian government. It is difficult to assess Belgian colonial achievements. Michel Struelens suggests that there was a positive side to Belgium's rule:

At the time of independence, the per capita income in the ('ongo) was \$88. This gave the Congo one of the highest living standards

14 David N. Gibbs, The Political Economy of Third World Intervention (Chicago: $U$ of Chicago P, 1991) 43.

15 David N. Gibbs, The Political Economy of Third World Intervention (Chicago: I of Chicago P, 1991) 44. 
in Black Africa. In 1959, the last full year for which detailed statistics are available, $40 \%$ of the annual production-amounting to $\$ 1.2$ billion-was exported. The Congo could proudly lay claim to a balanced economy and, thanks to important investments from Europe (mostly Belgian), it enjoyed modern industries, an adequate transportation network and an advanced agricultural system.1n

I'his assessment, however, must be balanced by the horrific legacy of Leopold. A 1919 Belgian government report concluded that the "Congolese population had declined by half during colonial rule," and oral tradition in the Congo maintained that the rubber policy was "a greater cause of death and depopulation than either the scourge of sleeping sickness or the periodic ravages of smallpox." 17 For the Congolese, Belgian rule, even when placed in the best possible light, was certainly seen as much less than a mixed blessing. In a speech delivered during the Congolese independence ceremonies, the new Prime Minister, Patrice I.umumba, denounced the colonial legacy of his no' country as one "of 'atrocious sufferings' and 'humiliating bondage,' filled with 'ironies, insults, blows which we had to endure morning, noon, and night because we were "Negroes. "1k

Relative to the European colonial powers, Canada's interest in Africa was modest at best. Both in terms of foreign and economic relations. Canada lagged behind most other developed nations in the establishment of links with the African continent and its newly independent states. In the early twentieth century, missionaries accounted for the earliest and most consistent (anadian presence in Africa. Notably, even at the time of the Congo crisis, the

\footnotetext{
In Michel Struelens, The United Nations in the Congo or O.N.U.C. and International lolitics (Brussels: Max Arnold Publisher, 1976) 36.

17 I avid N. Gibbs, The Political Economy of Third World Intervention (Chicago: $U$ of (hicago P, 1991) 46-49. $1 \% .5) 4$.

It lirnest W. l.efever, Crisis in the Congo (Washington D.C.: The Brookings Institution,
} 
vast majority of Canadians living there were missionaries. In 1959, 49 Roman Catholic and 275 Protestant missionaries were living in (ongo, Angola and Mozambique. In the Congo, these were predominantly Mennonites.19 Although the relationship between Africa and Canada was limited in scope, Diefenbaker and his Minister of External Affairs H loward Green were well dis; rosed to the idea that Canada might play a greater role in that part of the world. In fact, Green was partly responsible for I:xternal Affairs' initial interest in Africa.20 In addition, Diefenbaker took the initiative at the Commonwealth Prime Ministers' Conference of May 1960 to expand development assistance to include, not only the Asian ('ommonwealth countries that had benefited from the Colombo Plan, but also African Commonwealth countries. By September of that year, Canada pledged to contribute \$10.5 million to establish a Special Commonwealth African Assistance Plan.21 To a degree, he was motivated to do this by his fear that developing nations might be susceptible to Soviet overtures if their needs for assistance were not met by developed countries in the West. This concern ultimately became a central consideration in the I'rime Minister's foreign policy decisions relating to the Congo.

Early relations with African countries were usually with members of the Commonwealth. Canada's membership in this organisation facilitated the development of these relations. Essentially, however, African countries often knew little of the country except that it was not a great power and that it did not have colonies. Both of these considerations greatly enhanced its image,

19 Douglas Anglin, "Towards a Canadian Policy on Africa," International Journal 15.4 (Autumn, 1960) 293-294.

20 Douglas Anglin, "Towards a Canadian Policy on Africa," International Iournal 15.4 (Autumn, 1960) 290.

21 John G. Diefenbaker, One Canada, 3 vols. (1 orontu: Macmillan of ('anada, 1975, 1976, 1977) 2: 193-194. 
especially when compared with other Western countries. Canada's importance and appeal as a potential ally stemmed principally from its access to the powerful democracies - particularly the United States. Diefenbaker perceived the opportunity for Canada to enhance its image abroad by taking the lead in the formulation of constructive policies towards Africa. In effect, this could have increased Canada's influence with the developing and nonaligned nations, even though Canada was industrialised and Westernaligned. This goal was not easy to achieve and met with mixed results. In the UN General Assembly, Canada was sometimes reluctant to vote with African nations on issues significant to them. This did not go unnoticed. Canadians were sometimes perceived as "unsympathetic to African aspirations" and the Canadian delegation to the UN was known to many as the "total abstainers" because they often avoided taking a stand on significant votes. 22

Although the government professed a concern and interest in Africa, in reality Canada was soreiy under-represented by diplomatic missions there and few resources were devoted exclusively to Africa at External Affairs. The Commonwealth Division at External was responsible for all of Africa south of the Sahara and it was not until 1956 that a single desk officer in that division was appointed to cover African affairs. By 1959, three officers staffed an African section and consideration was given to the establishment of a fullfledged African division. By comparison, the United States was far ahead of C'anada in the development of a diplomatic corps specialising in Africa. While a single Canadian desk officer struggled to keep up with the frantic pace of events during the Congo crisis, and in fact was still responsible for all of the rest of Africa south of the Sahara, there was in the U.S. a Bureau of

22 Douglas Anglin, "Towards a Canadian Policy on Africa," International lournal 15.4 (Autumn, 1960) 298-307. 
African Affairs, w:th a staff of more than 70 that was headed by an Assistant Secretary of State.23 Of course it should come as no surprise that the Americans, given their greater interests, would naturally have more diplomats and officials to serve and study Airica, but the vast difference between the two countries is even larger than one might expect.

Nevertheless, the Belgian Congo was served relatively well by Canadian officials. In 1960, at the time of the Congo crisis, there were only 5 Canadian diplomatic posts in all of Africa. The Congo was among the five, with a Consulate General, and was the only one of the five posts located in a country that was not a Commonwealth nation. Furthermore, before the Canadian Consulate General in Leopoldville was established, the Congo had been the location of one of only three Trade Commissions in Africa since 1946.

The Canadian and the Belgian Congo economies had a great deal in common. In many respects, the Congo was to Belgium what Canada had been to Great Britain. The colony was a rich source of raw materials that quickly became both an integral and significant component of the Belgian economy. In area, it was immense - some eighty times the size of Belgium. Much like the St. Lawrence, the Congo River was a great water route for exploration, transportation and commerce. Although the Congo provided navigable waterways thousands of miles in length, it was necessary to construct railroads to develop and exploit resources adequately. The Benguella and Central Congo Railways are the Congolese equivalents of the Canadian National and Pacific Railways. Throughout the first half of the twentieth century, the colony's raw materials provided a sound economic

23 Douglas Anglin, "Towards a Canadian Policy on Africa," International Journal 15.4 (Autumn, 1960) 299-300, 306. 
basis for growth and development. Copper and palm oil were as important as the cod, beaver and wheat were to Canada. Moreover, I.H. Ausman, the (anadian Trade Commissioner in Leopoldville during the late forties, noted that ('anada and the Congo had similar natural resources, including: corn, copper, cobalt, zinc, gold, radium and uranium.24 Beginning in the midtwenties, Trade and Commerce officials fostered the development of trade between Canada and Central Africa. By 1960 Canadian exports to the Congo had reached approximately $\$ 1.3$ million, but this was not a truly significant amount in relation to total Canadian trade.

Information concerning the Belgian Congo and opportunities for Canadian trade there was gathered in the early years through a number of tours conducted by Trade Commissioners operating from South Africa. G.R. Stevens visited Central Africa on such a tour as early as 1926-27. Upon his return to Cape Town, he filed a series of reports that were subsequently printed in the Commercial Intelligence Journal, a periodical distributed throughout Canada by the Department of Trade and Commerce. Stevens was astute in his observations. Many of the conclusions that he drew from this trip remained applicable to trade between the Congo and Canada for decades to come.

It was apparent to Stevens that Katanga was a crucial region. Copper was identified as the most important resource or raw material. He noted that the "copper mines of the Katanga overshadowed all other productivity in that area." 25 Numerous transportation links between Elizabethville, Katanga's distribution centre, and the surrounding regions further demonstrated the

\footnotetext{
24 L.H. Ausman, "Belgian Congo Enjoyed Favourable Economic Conditions Last Year," Foreign Trade 8 (1950): 268 .

25 (i.R. Stevens, "Irade of the African Sub-Continent: General, Production \& Natural Resources," Commercial Intelligence lournal 36.1216 (1927): 597.
} 
area's significance. Not only were there four additional handlings to carry cargo from Katanga to the sea, but a full four-fifths of the traffic on the neighbouring Tanganyika railway consisted of Katanga cargo.2n Stevens alsio commented on the substantial British investments in the region.

Construction of the Benguella railway was financed by a British railway company that held large interests in the copper industry. Loans to complete the railway were even underwritten by the British government.27 Mineral wealth and industrial development was highly concentrated in the Katanga Region, and was financed primarily by Belgian and British interests. This had serious implications for the Colony during the secession crisis that occurred within weeks of independence from Belgium. By contrast, the economy of the Lower Congo was dominated by agriculture. Kinshasa (or Leopoldville) was the chief distribution centre of this region.

Stevens' assessment of the prospects for direct trade between ('anada and the Belgian Congo was not very promising. Acknowledging the dominant role that Belgian and British distributors played within the colony, Stevens asserted that access to the market of the Belgian ('ongo was possible only through distributors in London and Brussels - "in the hinterland of Africa, Canadian goods are unknown." $2 x$ He believed that it would be very difficult for Canadian goods to make their way into the market, given that traders already had old and established sources of supplies. ${ }^{29}$ Referring to

26 G.R. Stevens, "Trade of the African Sub-Continent: Communications," Commercial Intelligence lournal 36.1217 (1927): 635.

27 G.R. Stevens, "Trade of the African Sub-Continent: Communications," Commercial Intelligence Journal 36.1217 (1927): 635.

28 G.R. Stevens, "Trade of the African Sub-Continent: Central African Ciroup - Belgian Congo \& Angola," Commercial Intelligence Journal 37.1247 (1927): 891.

29 G.R. Stevens, "Trade of the African Sub-Continent: Distribution Systems," Commercial Intelligence Journal 36.1218 (1927): 669. 
mining supplies, he illustrated this point.

It is practically impossible for any local distributor, either merchant or agent, to obtain any particular share of the large mining business of the copper monopoly. This trust buys through its Brussels head office to a large extent, and when forced to obtain supplies locally, do so through representatives i.t Bulawayo and in Johannesburg, where its agent is a member of the Witwaterrand Commercial Exchange. For all mining supplies of every type therefore a local approach is practically useless. This situation promises to be permanent. 30

Furthermore, the demographic breakdown $(12,000,000$ Africans to 10,000 Jiuropeans) 31 was not conducive to trade with Canada. Stevens remarked, "In so far as the native trade is concerned, the goods which he wants are not obtainable in Canada." 32 The largest of the two markets in the Belgian Congo was indifferent to Canadian trade guods.

The major European powers had declared the Belgian Congo a free trade zone in the Congo Basin Agreement of 1885. In effect, this agrc. ment created a level playing field in the Congo. Any country could tracle there and have its goods enter either duty free or at a rate of duty that was applied to all triding partners equally. It will be recalled that this arrangement was readily accepted by Leopold II and the other European colonial powers because in theory it served to enrich all. Goods from Belgium, however, ultimately profited from both established trading networks between colony and motherland and also reduced shipping costs between Belgian and Congolese ports.

31) G.R. Stevens, "Trade of the African Sub-Continent: Distribution Systems," Commercial Intelligence Journal 36.1218 (1927): 670.

31 G.R. Stever.. "Trade of the African Sub-Continent: General, Production \& Natural Resources," Commersial Intelligence lournal 36.1216 (1927): 594.

32 (i.R. Stevens, "Trade of the African Sub-Continent: Central African Group - Belgian (ongo \& Angola," Commercial Intelligence lournal 37.1247 (1927): 8 71. 
The routing and transport of goods between ('andada and the Belgian Congo placed Canadian goods at a disadvantage in one other respect.

Canadian businesses were reluctant to ship merchandise without payment; buyers in the Congo, however, were accustomed to the practicess of the Belgian supply and trading cartels who would wait for payment until after customers received their goods and had benefited from a payment grace period. Maurice Bélanger, Assistant Trade Commissioner in Belgium, described the transportation system for the benefit of (anadian manufacturers:

A shipment of Canadian goods unloaded at Matadi and consigned to Elizabethville is carried by rail to lesopoldville, by boat to Port Francqui on the Kasai River, and by train from l'ort Francqui to Elizabethville. A shipment from Matadi to Albertville will be carried by rail to Léopoldville (250) miles), by river barge to Stanleyville (1,000 miles), by train to l'onthierville (75 miles), by boat to Kindu (200 miles), by train to Kongolo (220) miles), by boat to Kabalo ( 60 miles), and finally by train to Albertville (170 miles). 33

Canadian businesses were understandably concerned about the risks involved in shipping overseas to such remote clients, particularly on a ( $(1) .1$ ). basis. Bélangeı's report probably reinforced these concerns. By not having representatives in the Congo, it was particularly difficult to judge the reliability of potential customers or to have confidence in local means of transportation. As a result, direct trade with the Congo was inhibited and was more often conducted through established Belgian channels and networks.

In the twenties and thirties, trade followed the pattern of global economic trends. The twenties saw a boom in development within the Congo. The construction of new roads and public works, combined with the

33 Maurice Bélanger, "The Belgian Congo as a Market: Cieneral," ( ommenercial Intelligence Journal 57.1759 (1937): 658-9. 
need for agricultural and industrial equipment, meant increased purchases abroad. ('anada benefited from this, but the Congo's major trading partners (Belgium, Britain and the U.S.) were the real winners. The great depression of the thirties, however, brought a quick end to this development and caused a downturn in trade. In addition, by 1936 the Japanese were aggressively pursuing trade, especially in items for the more populous and lucrative Native Congolese market. They took full advantage of the free trade provisions of the Congo Basin Agreement. Imports from Japan surpassed in value even those of Britain, assuming the number two trading position.34 Belgium, however, retained her position as her colony's most important trading partner by a wide margin. Banks and the local government helped to ensure this by encouraging the major colonial business interests to purchase, whenever possible, supplies from Belgium. Stringent competition from both the Belgians and Japanese coincided with the depression to limit the possibilities for trade.

The outbreak of hostilities in Europe in 1939 created numerous opportunities for Canadian businesses. Germany had been a major trading partner with the Belgian Congo, ranking fifth in 1938 following: Belgium, Japan, U.S.A. and Great Britain. ${ }^{35}$ Hostilities in Europe completely reversed ('anadian manufacturers' shipping disadvantages. As shipping from Europe bicame increasingly dangerous and unpredictable, Congolese merchants turned in increasing numbers to sources of trade distant from European ports. Both American and Canadian businesses benefited from this turn of events. Cionds were still not shipped directly from Canada to the Congo. Instead, trade

It Maurice Bélanger, "The Belgian Congo as a Market: Foreign Trade in 1936," comnerchal Intelligence Journal 57.1760 (1937): 560 .

is Mlaurice Bélanger, 22 February 1940: N.A.C., RCi20, Vol. 60, File \$ 19775, pt. 1. 
was easily routed through New York and the possibility that Canadian shippers might add a Congo stop to their South African routes was considered. The war also disrupted regular communications between merchants in the Congo and their suppliers in Belgium. To seek supplies in the U.S. and Canada, they circumvented established trade with the indent firms in Belgium. By removing the previous obstacles of shipping and established trade networks, World War II proved to be a huge impetus to increased trade.

In August of 1940, Max Horn, Counsellor of the Belgian Ciovernment to the Belgian Ministry of Colonies, toured (anada and the United States to discuss Congo trade issues. His aim was to develop new outlets for the colony's 800 million dollars (U.S.) worth of exports, 75 per cent of which were normally purchased by Belgium. ${ }^{3 t}$ The Belgian government had already concluded an agreement with Britain, by which the British agreed to "... grant the Belgian Colonies a fair share in its imports of colonial produce, the Belgian Colonies being treated in that respect on an equal footing with British possessions." 37 The Congo was blessed with a wealth of minerals and many, such as uranium, had strategic value in the Allied war effort. British needs provided an outlet for the Congo's gold, tin, rubber, diamonds and a number of vegetable products. Horn, however, was still anxious to find buyers for another 169,000 tons of ore of various types and 272,000 tons of vegetable products, including palm oil and cotton. In addition, Itorn believed the Congo might be a good market for (anadian trade-goods, machinery, and rolling-stock. Because much of the mined ore had been refined in Belgium previously, potential arrangements to refine Belgian ('ongo ores in ('anada

36 Désy to Skelton, 5 August 1940: N.A.C., R(;20, Vol. ho, lille \#19775, pl. I.

17 Desy to Skelton, 5 August 1940: N.A.C., R(;20, Vol. 61, 1.ike \#19775, pl. I. 
were also suggested.

The most intriguing consequence of Horn's visit was a tentative trade agreement that granted trade concessions to the Congo. In effect, this agreement placed the Congo on the same footing as parts of the British limpire. Its goods would have been imported at the Imperial preferential rates of duty and would have been exempt from the war exchange tax. Trade and Commerce officials believed that the Congo stood to gain more from the agreement than did Canada, but felt justified in suggesting its approval because it enabled Canada to purchase Congolese goods in sterling and because the Congo was an active participant in the war. The Minister of Trade and Commerce, James MacKinnon, gave preliminary approval to the idea, which was then forwarded to External for consultation with the British. At this stage, however, problems were encountered. The British believed that the "extension to the Belgian Congo of Imperial Prefe:ence as such would raise very large and difficult issues in relation to both Empire and other foreign countries." 38 The British government had agreed to provide temporary assistance to the Belgian Congo in the form of a purchase agreement, but had deliberately avoided requests to extend the Imperial Preference to imports from both Belgium and the Belgian Congo. Now, the British hoped that Canada would be "willing to avoid any concession in the Belgian Congo which would affect the principle of Imperial Preference." 39 Much to Horn's disappointment, the Canadian government chose not to follow through on the tentative agreement. This whole episode is interesting in that it reveals the extent to which Ottawa was willing to go to encourage and develop trade with the Congn. If it had not been for British objections,

38 Cranborne to Massey, 27 March 1941: N.A.C., RG20, Vol. 60, File\#19775, pt. 1.

34 (ranborne to Massey, 27 March 1941: N.A.C., RG20, Vol. 60, File\#19775, pt. 1. 
Canada was willing to treat the Belgian colony as if it were part of the British Empire.

By the end of the war, seventy per cent of Congo imports came from either the United States or Canada.40 The break with Hurupe caused by the war resulted in a significant reorientation of Congolese relations towards Britain and North America. This was especially true of strategic minerals. $A$ secret trade agreement was concluded with the United States that provided uranium for the Manhattan Project. In hopes of retaining and enlarging their share of the Congolese market in the post-war period, Canadian officials opened a Trade Mission in October, 1946. The following year the colony was visited by Trade and Commerce Minister MacKinnon. Throughout the late forties, Belgium began to recover its markets in the Congo and by 1948 it had resumed its position as the colony's most important trading partner.41 The United States remained second, and while it is difficult to precisely determine Canada's position relative to other countries trading with the Congo, it seems that Canada remained a top twelve trading partner until the early fifties. 42 Wheat flour was the most important Canadian export to the Congo. Canadian exports to the Congo fell off during the late fifties, principally because of competition and periodic downturns in the Congolese economy.

Canadian efforts to retain the market share it achieved during the war were therefore only partially successful. Canadian exports never fell to prewar levels, but could not be sustained at the heights they achieved during the

40 Heasman to Newman, 27 November 1947: N.A.C., RG20, Vol. 329, File\#'T11681.

41 L.H. Ausman, "Canada Achieving Importance as Supplier to Belgian Congo," Lorcign Trade 5 (1949): 1262.

42 Comparative statistics from Congolese sources place Canada in the top 20 importing and exporting countries; however, these statistics did not take into account the rela lively large number of Canadian goods reaching the Congo via other nations (i.e. Canadian goods shipped to the Congo through Belgium, the U.S., etc.). For this reason, (anadian statistics are a better indicator of the true level of trade. 
early fifties. Overall, Canadian economic interest in Africa was limited-under one and a half per cent of total Canadian exports and less than half of one per cent of imports. Only twenty Canadian companies operated in Africa, but the majority were quite small. Three companies accounted for two-third of total investment; the largest was Aluminum Limited with African holdings totalling \$30 million.43

During the mid-fifties, Canadian owned Aluminum Limited became involved in a Hydroelectricity project that sought to harness the energy of the Congo River. Hydroelectric facilities were seen as the key to economic development and increased industrialisation in the Congo. In particular, a 200 mile stretch of river between Leopoldville and Matadi, that came to be known as the 'Inga site,' was considered the most promising location for a massive power installation. It was believed that this one facility could provide the equivalent of $1 / 15$ the power produced in the United States. In April of 1955, the Belgian Minister of Colonies announced that Canadian and American specialists had toured the Inga site to evaluate its potential-much to the dismay of officials of Aluminum Limited who were "most anxious to keep out of the limelight its interest in the Congo." 44 They were fortunate that the Belgian press chose to focus more on the implications of American involvement than on participation by Canadians.

A great deal of secrecy surrounded the circumstances and negotiations of Aluminum Limited's interest in Inga. The Société Générale, a large conglomerate of mostly Belgian financial interests, opposed the Belgian government's attempts to involve foreign investment in the project and for

4.3 Douglas Anglin, "Towards a Canad,an Policy on Africa," International lournal 15.4 (Aulumn, 1960) 294-297.

44 Summary of Despatch No. 279, 6 June 1955: N.A.C., RG25, Vol. 3270, File \#6386-40 pit. 1. 
this reason Aluminum Limited wanted to keep as low a profile as possible so as not to antagonise Belgian nationalist sentiments about the Congo. A company representative in Belgium also feared that too much may be made of "the problem" in Ottawa. For these reasons, the Canadian Ambassador did not even consult or approach the Belgian Ministry of Colonies on the matter. There was yet another motive for the secrecy. Aluminum Limited hoped to "secure control" over the project's construction and the "future direction of the power site at least for a prescribed period." 45 These objectives, it was felt, would also run counter to the wishes of both the Belgian public and the Société Général and so they did not want them revealed until well after negotiations with the Belgian Government were underway.

It was essential to the project's success for industries that consumed large quantities of power to co-locate near the proposed site. Aluminum Limited required such a power source to refine aluminum, and American officials were interested in the project as a means of refining uranium destined for the U.S. At the time, $12 \%$ to $15 \%$ of electric energy consumed in the States went into the refinement of uranium.4h Thus, the cooperation of both American and Canadian interests was imperative to the success of Inga. The Canadian Ambassador was encouraged to continue his discreet meetings with Aluminum Limited's representative, and in Ottawa his reports were forwarded to Canadian officials at the International Joint Commission and the Atomic Energy Control Board who had expressed "keen interest." While the information he obtained was useful to officials at home, the Ambassador was nonetheless urged not to compromise relations between the Eimbassy and Belgian authorities by his meetings with Aluminum Limited. The Canadian

45 Despatch No. 307, 8 June 1955: N.A.C., RC25, Vol. 3270, File\#6386-40 pt. 1. 4h Despatch No. 390, 13 July 1955: N.A.C., RC:25, Vol. 3270, File \#63364.40 pt. 1. 
government was interested by the possibility of Canadian investment in the Congo, but this was tempered by its desire not to offend or undermine Belgian colonial sentiments.

Proportionately, American trade and investment with Africa was far greater. The one instance of considerable Canadian involvement and investment in a venture in the Belgian Congo was met with interest, but circumspect caution. While it appears that Canadian trade with the Belgian Congo was at times substantial, it is unlikely that it was so significant as to become a factor in the decisions to deploy Canadian armed forces with UNOC.

Cariadian relations with the Belgian Congo were influenced first and foremost by relations with its mother country. Canada was reluctant to jeopardise its relations with Belgium, as evidenced by Canadian involvement in Inga; yet, Canadian officials in Ottawa and Leopoldville were sometimes critical of Belgium's colonial policies. It was a quite a balancing act. The Congo "was one of the most valuable colonies in Africa" and contributed greatly to Belgium's economic well-being. In 1960, the implications for Belgium of a political break with the Congo were estimated to be: a $7 \%$ loss of total receipts in balance of payments resulting from the loss of the Congolese export market; a 30\% loss of overseas operations of transport and insurance companies; a loss of $\$ 77$ million in revenue from investments; a $2 \%$ increase in the Belgian rate of unemployment; and a decrease of \$140-156 million in the Belgian budget to cover the costs of reintegrating 10,000 administrative officers, paying the share of public debt guaranteed by Belgium, paying former Colonial servants who were normally paid by the Congo and to compensate 
for the loss of tax revenue.47 The Congo was significant to Belgium for less tangible reasons as well-it was a source of pride. The Canadian Ambassador to Brussels in 1945 drew attention to this in a memo to External Affairs. He noted that Belgium's crushing defeat within days of the German thrust westward in May 1940 did nothing to foster the impression,

... that they have been able to play in this war a part corresponding to their influence and interests in Europe. Furthermore throughout the occupation all their resources, human and material were under the control of the Germans and they are aware that to a certain extent such resource have been used by the enemy against the Allies. These considerations are not expressed but they are deeply felt and they are source of humiliation.48

These humiliating events and circumstances were offset by Belgian pride in the valuable economic and strategic role played by the Congo during the war. For example, critical Congolese mineral resources, including uranium, were made available to the Allied war effort. The Belgians watched increased British and American war-time involvement with its $c$ ony with suspicion and the Canadian Ambassador warned that they would be uneasy about U.S. and U.K. intentions when post-war colonial arrangements were addressed. Belgian colonial policy was essentially paternalistic. Opinion at External on Belgium's policy was divided, perhaps typical of a difference in views on decolonisation gerierally. The goal of Belgian policy was to attain a partnership between Europeans and Native Africans, but the time frame for achieving this goal was unclear. Other colonial powers concentrated on developing a general social awareness that would result in increased political

47 The economic significance of the Congo to Belgium is discussed in David N. Cibbs, "Dag Hammarskjold, the United Nations, and the Congo Crisis of 1960-1: a Reinterpretation," The Journal of Modern African Studies 31.1 (1993): 163-74 and Stephen R. Weissman, American Foreign Policy in the Congo, 1960-1964 (Ithaca: Cornell U P. 1974): p. 24.

48 Letter No. 173, 5 April 1945: N.A.C., RG25, Vol. 3270, File \#6.346-40 pt. 1. 
responsibility. Belgium, on the other hand, placed emphasis on the economic well-being of the native Congolese and avoided measures which might lead to the development of a Native élite. For example, primary and secondary school education for Natives was far more common in the Congo than in other African colonies. University education was uncommon because Belgian authorities rarely permitted Congolese to study in Belgium, and not at all in other countries. To the Belgians, it seemed that the approach taken by the other colonial powers too often developed an élite that lacked judgment and political maturity. They encouraged the development of a stable Congolese middle class, and gradually dispensed limited political rights to vote in established urban areas when it was sensed that not to do so might result in Native demands for an even greater political role.49

An interesting exchange of views in April of 1957 between Escott Reid, High Commissioner to India, and C.P. Hébert, Ambassador to Belgium, demonstrates the opposing views within External towards decolonisation and Belgian policy in the Congo. In preparation for a visit to Ottawa, by Indian Prime Minister Jawaharlal Nehru, Reid had written a memorandum on colonialism in which he suggested that the colonial powers in Africa should place their non-self-governing territories under the aegis of the UN and fix a date by which self-government for each territory should be achieved. He believed the African decolonisation process should take no longer than twenty years.

Hêbert disagreed. He argued that the Congo was an "inchoate mass" that a century of Belgian administration had been unable to mould into a

44 Bachground Paper on the Belgian Congo, 1956: N.A.C., RG25, Vol. 7033, File \#638641, Pt. 2 and II:A Numbered I.etter 142, 21 February 1958: N.A.C., RG25, Vol. 7033, File \#638640, pt. 2.2. 
uniform society. Hebert was kind in his assessment of Belgian achievements and motives. He wrote,

The Congo ... is inhabited by very backward peoples few of whom can have any conception of government ... In the circumstances it is inconceivable that, twenty years from now, these peoples should be asked to assume the direction of their own affairs through a grant of self-government. ... Belgium's reluctance to make any such grant on her own initiative and her resistance to UN pressure cannot be said to stem entirely from imperial ambitions supported by vested economic interests.

... Belgium's achievements in the Congo do her credit. ... Despite this progress however it is perhaps asking a great deal to expect a transition in three generations (from 1890 to 1980) from tribal warfare and cannibalism to twentieth century standards of justice, political development, orderly and responsible government.

If, in spite of the existing situation, Belgium is forced to yield to UN pressures and grant to the Congolese selfdetermination in twenty years time, the consequences are not difficult to imagine. ... the resultant regime would be far from stable economically or politically and would soon be in the hands of semi-trained Congolese who would either exploit their fellows for their own benefit or for the benefit of some other foreign power, possibly the USSR. In either case UN help would probably be rejected on the grounds of infringement of sovereignty and interference in domestic affairs.50

In some ways, Hébert's comments seem almost prophetic. He predicted some of the important issues associated with the Congo crisis, including fear of Soviet penetration and the the legal difficulties that could arise should the UN consider involvement in a crisis that was essentially a matter of domestic jurisdiction.

Reid countered Hébert's remarks in a typically clear and effective manner. He conceded that it might take thirty years before independence 
could be granted, instead of the twenty years he had previously stated.51 Using the example of India, he argued that it was not impossible for a diverse society to still achieve independence. Moreover, he noted that the Congolese were on average in a better economic position than were Indians at a similar stage in that country's development. Finally, he took issue with the idea that the ('ongolese could not meet twentieth century standards of justice, political development and orderly and responsible government. He cited a long list of leading twentieth century political figures that failed to meet these same standards, including Stalin, Hitler, Mussolini and Franco. 52

In subsequent years, as we will see, most Canadian officials held the Belgians partially responsible for the Congo crisis for not having enough faith in the Congolese to assist them fully in preparing for independence. They questioned the Belgian wisdom that it was a favour to the Africans to withhold independence until such time as they had sufficiently developed a responsible political consciousness. In this sense, later views and attitudes had more in common with Reid than Hébert.

The slow pace of progress towards independence contributed to deteriorating race relations. By the 1950s, increased industrialisation caused Native Congolese to migrate from rural to urban areas. This concentration of people, combined with a cyclical economy that resulted in labour shortages and then unemployment, aggravated an already tense situation. Apartheid was not a legal fact in the Congo, but in economic and social terms its impact

51 It seems peculiar that a mere three years before the Congo crisis it could be assumed that independence could be postponed for three decades. Relative calm and stability during most of the 1950s lulled people into a sense of false security and this perception was not uncommon. See: Michael Struelens, The United Nations in the Congo or O.N.U.C. and International Politics (Brussels: Max Arnold, 1976) 18-19. He refers to a leading Leopoldville newspaper that suggested 1985, the centennial of the establishment of the Congo Free State, as suitable date for independence.

52 Reid to Hébert, 30 April 1957; N.A.C., RG25, Vol. 7033, File\#6386-40 pt. 2.2. 
was every bit as real there as in South Africa. In April 1951, R.F. Louglas, an Air Attache with the Royal Canadian Air Force, was sent to the (ongo to report on conditions. He was received well by Belgian officials and submitted a detailed report, covering everything from the history of the colony, to its geography and military installations. On the issue of White/Native relations, he reported on the living and work conditions of the Congolese who served within the Belgian Congo army known as the Force Publique. He said:

Training natives requires tremendous patience, and the officers of the Armed Forces in the Congo possess this to a very great degree. The result is a happy situation among the native soldiers, and I believe the same applies to most of the civilian organizations. In general, the native who goes to work for the white man immediately enjoys a far better life than he knows in his native village. The natives seem to realize this. There is a complete colour bar in the Congo, and the natives have nothing approaching the rights of white men. It is common practice in the cities to have the native quarter and to ensure that the natives are in there by 9 p.m. There are separate railway cars, waiting rooms, restaurants and sometimes stores, for the natives. The natives have no voice in the Covernment. At present and for a long time to come, this system seems to be the only practical one.53

Douglas' interpretation of relations between the Whites and the Congolese was simplistic in its optimism, but does provide a good picture of the living conditions of the Natives. The situation Douglas described as 'happy' was perceived quite differently by the Congolese. The discriminatory working conditions and condescending attitudes of Belgian officers ultimately led to a revolt of Native soldiers in the Force Publique within days of Independence.

Douglas was not alone in underestimating the deleterious effects of the persistent racism and discrimination that characterised society in the ('ongo.

53 R.F. Douglas, 8 June 1951: N.A.C., R(;25, Vol. 3270, File $\$ 63864$ 4) pt. I. 
A.13. Brodie, the Canadian Trade Commissioner, held favourable views of the Belgian administration's Native policies. He believed that the Belgians had no desire to suppress the Africans, but rather were interested in elevating them to become, "healthier and more useful citizen[s]."54 Official policy was meant to be benevolently paternalistic, and while it is possible that Belgian colonial administrators believed that they were sincerely assisting in the development of a new nation, the racist views and practices of the 'nonofficial European' were strengthened and given credence by this notion of the need to 'civilise the savage.' In their decision to focus on long term political goals for the colony, the Belgians failed to recognise that the seeds of discontent were being sowed in the segregated Native quarters of the cities.

When riots began to break out with some frequency in 1959, it became apparent that relations between Natives and Whites were not as rosy as had been thought. European families resented the incorporation of native culture into the schonl curriculum, for both white and black students. K. Nyenhuis, the Canadian Trade Commissioner at the time, concurred with the liuropeans. In a report to External he suggested that "better subjects could be found since savagery is still very near the surface in most of the natives." 55 In addition, incidents between individual Natives and Whites assumed a new intensity of racial hatred and prominence. In late May, for example, two cars driven by whites were demolished and the occupants seriously injured by Congolese in retribution for the death of a Native women involved in a car accident carlier in the day. $5 n$

Stories of racially motivated violence contributed to a growing sense of pt. 1.

54 A.B. Brodie in D.W. Munro, 29 January 1952: N.A.C., RG25, Vol. 3270, File \#6386-40

55 k. Nyenhuis to Fvternal, 1 June 1959: N.A.C., RG25, Vol. 7033, File \#6.386-40 pt. 3.

5n k. Nyenhuis to Filernal, 1 lune 1959: N.A.C., RG25, Vol. 7033, File \#6.386-40 pt. 3. 
hysteria. In the fall, Nyenhuis toured the Fastern c'ongo and found tensions rising there too. He noted that most violence was between rival Native tribes, but that the rising level of violence left many Whites concerned:

Although no white people had suffered bodily or materially during the rioting, there was, nevertheless, the uneasy fecling that it would only take the slightest provocation, real or presumed, to unleash the latent hatred against the whites with the most abominable consequences. ... Therefore, the large majority of white citizens have heavily armed themselves. ...

The General behaviour of many blacks in luluabourg was sufficient indication that the respect for the white man is disappearing. Whatever animosities the blacks may foster amongst themselves, they would be united in taking bloxdy revenge for having been treated as inferiors, if not -vorse, for many years. 57

In a report filed the previous month, Nyenhuis noted that many Native Congolese expected to take over the possessions of Europeans once independence was granted, but that sentiments such as these were confined to urban dwelling Congolese. He believed that rural Natives had not changed their attitude towards Whites. Furopeans believed that minor political concessions to the Congolese resulted in the racial difficulties and that everything could be solved by taking economic measures to relieve the unemployment problem.5x Even as the colony edged closer and closer to the breaking point, the European residents still failed to appreciate the root cause of Native discontent-the paternalistic colonial policies and demeaning living conditions. Trade Commissioner Nyenhuis was late coming to this realisation, and seemed to share the view's of other IVhites living in the Congo.

57 K. Nyenhuis in Fixternal, 14 November 1954: V.A.C , RC:25, Vol. 7033, lille \#6 386 40) p. 3.2

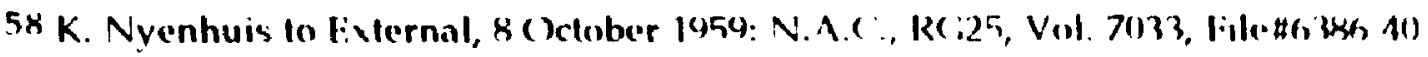
p. 3.2 
Indeed, the Belgian Congo was often seen as a model colony. The standard of living for Native ( ongolese was said to be among the highest of all colonised $\Lambda$ fricans. Improvements in economic well being, however, were not matched by increases in political rights or an amelioration in the social living conditions. The colony was ruled by a Governor-General and six provincial Covernors, and each of these officials was responsible to the (olonial Ministry in Brussels. Political parties appeared for the first time in 1957, during the first elections ever held in the colony. Voting was permitted in J.eopoldville, Elizabethville and Jadotville to choose local officials. Membership in political parties was usually based upon tribal allegiances. In spite of local reforms, there were no plans for decolonisation as late as 1959.

In January 1959 riots erupted in Leopoldville during a rally of the Association Culturelle des Ressortissants du Bas-Congo, (ABAKO) a political party headed by Joseph Kasavubu. At first the crowd was "small and orderly," but soon there were shouts for immediate independence. The police began to Danic and their Commissaire was knocked over while trying to arrest the party leaders. Police started to shoot in an effort to clear the crowd and pandemonium resulted. The crowds rampaged, looting stores in both African and Furopean neighbourhoods. Reinforcements from the Force Publique tried to cordon off the affected areas, but by nightfall disorder had spread throughout the Native quarter of the city. The Canadian Trade (ommissioner in Leopoldville later reported that "all white people walking or driving through the native (ity and the outskirts of Leopoldville were attacked with stones, iron bars, and anything handy, their cars smashed and burnt, some women disrok. t." Police arrested over 200 people including Kasavubu, and some 50 Africans were killed. Heavy unemployment was said 
to be one of the causes of the riot, but dissatisfaction with the level of political independence from Belgium was also a crucial factor. 54

After they were soundly criticised by the international community for their brutal suppression of the riots, the Belgian government finally unveilied its plan for self-determination in fall of 1959 . The plan called for complete independence by 1964, with various stages of political development in the interim. The pace of the plan was unacceptable to the (ongolese, and in fear of widespread riots, the Belgians agreed to hold a conference in lebruary 1960) to discuss the issue further. The conference produced a much faster schedule of reform, and drafted an interim constitution (the loi londamentale'), which identified the political inetitutions of the new state. Cieneral elections were scheduled for May, and independence was to be granted on June 31), 1960). Belgian intransigence was replaced by a spectacular pace of political reform.

Yet, in their new found haste to concede independence, the Belgians failed to adequately prepare the colony. The Congo completely lacked a native, effective administrative and political structure because of the Belgian decision to limit the number of Congolese permitted to pursuc positsecondary education. This was to have serious consequences for the first Congolese government, as they prepared to govern the vast territory they had gained.nil

The two politicians who would ultimately be the central figures in the Congo crisis were already prominent by the late fifties. Joseph Kasavubu,

\footnotetext{
${ }^{59}$ Brussels to External, 8 January 1959: N.A.C., RC;25, Vol. 70133, File $\left.\# 6336,40\right)$ p1. 3; K. Nyenhuis to USSEA, 8 January 1959: N.A.C., RC:25, Vol. 7033, liite\#h 336 40 pt. 3; Glazebrook, 30 January 1959: N.A.C., RC;25, Vol. 70.33, Iile \#6.346-40 pt. 3.

6) Ernest W. Lefever, Crisis in the Congo (Washington 1).C :. I he Brooking, Instltuluon, 1965) 6-8; David N. Gibbs, The Political Economy of Third World Intervention (c hicago: $1 /$ of Chicago P, 1991) 73-76; Michel Struelens, The United Nations in the (ongo or (1).N.I.C and International Politics (Brussels: Max Arnold Publisher, 1976) 1819.
} 
arrested during the January riots, has already been mentioned as the President of $\mathrm{ABAKO}$. He was educated in (atholic seminaries and after working as a teacher and in administration, he was elected Mayor of Dendale (in the Native quarter of Leopoldville) in the local elections of 1958.61 Nyenhuis, the ('anadian Irade Cosımissioner, reported that the most significant political event in May of '59, was Kasavubu's return from detention in Belgium. lividently, his political supporters heralded his return "as the beginning of the millennium" and gave him a new light blue Cadillac convertible to mark the occasion 12 In these early months, he was not so popular with the Belgian authorities, who regarded him as a "separatist and an intriguer." 63

Patrice Lumumba was the other key figure. He was born in Kasai, and educated in Stanleyville. After moving to Leopoldville, he became a sales manager for a brewery. He founded the Mouvement National Congolais (MNC), the only political party that could ever truly claim to be national in membership in the early years of the Congo's independence. He too was jailed for his political activities, but was able to attend the Round Table Conference in Belgium, "from which he emerged as the acknowledged leader of the Congolese." $n 4$ He was initially seen as a moderate, and "went out of his way to allay fears that once the Africans had obtained independence in the Congo they would repudiate the white man and confiscate his property." 65 His early pronouncements and actions earned him the trust of the Belgians, who preferred him to Kasavubu at first. Following the May elections, he

ol Catherine Hoskyns, The Congo Since Independence: January 1960-December 1961 (l,ondon: ( X ford U P, 1965) 500.

n2 Nyenhuis to USSEA, 1 June 1959: N.A.C., RG25, Vol. 7033, File\#6380-40, pt. 3.

n.3 Rosalyn Higgins, United Nations l'eacekeepinge 1946-1967: Documents and Commentary, 4 vols. (Oxford: Oxford U P, 1980) 3: 9. n4 (atherine Hoskyns, The Congo Since Independence: January 1960-December 1961 (l.ondon: (Mford U P, 1\%65) 500. n5 Can Amb Bru to SSEA, 29 April 1959: N.A.C., RCi25, Vol. 7033, File\#6386-40, pt. 3. 
increasingly attacked Belgium and "Belgian political and public opinion began to regard him as unstable and inclined to accept support from communist countries."

The Canadian Ambassador in Belgium did not wholeheartedly accept this Belgian view. He assessed Lumumba as,

... a born politician and the most astute of the Congolese political leaders. He has chameleon-like characteristics which enable him to change his position suddenly and without worrying too much about being consistent. Lumumba is energetic, self-centred and very ambitious. ... Lumumba's chief drawback is his apparent inability to get along with people who work with him. ... Another drawback is that he is disliked and distrusted by most of the other Congolese leaders ... they suspect him of dictatorial tendencies. ... In our view Lumumba is basically an opportunist and we doubt if he would let the fact that he got financial support from a certain quarte. [Communists] influence his policy. ${ }^{7} 7$

The Belgian Government would from time to time raise the issue of Communist involvement to gain support for its policies in the (ongo. At this early stage in his career, it is likely that they were overreacting and that the Canadian assessment of Lumumba is the more accurate. later, once the Congo began to descend into anarchy and Lumumba began to fish around for external support, the possibility that he may have sought assistance from the Soviets needs to be much more closely examined.

In December 1949, a news story appeared in the l'aris edition of the New York Herald Tribune calling attention to the threat posed by communism to the Belgian Congo. Because the story was riddled with inaccuracies, in and of itself it is relatively unimportant but the reaction it received and the diplomatic correspondence it spawned is interesting as a

hn Rosalyn Higgins, Uniled Nations Peacekeeping, 1946.1967: 1)ocume.nls and Commentary, 4 vols. (Oxford: Oxford U P, 1980) 3: 10.

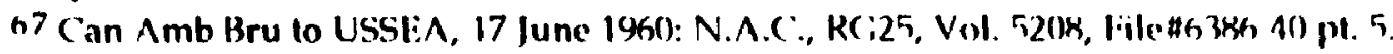


demonstration of the views of Canadian diplomats regarding the seriousness of the threat of Soviet penetration in the Congo. The article, entitled "Red Danger Reported in Congo," purported to be based on a "Belgian state security report" written by a "state security officer." $h$ s Among other things, the article suggested that the Soviets had sent sixty Native Congolese to Moscow in order to take a special course in modern witchcraft. Apparently, they then returned to rural areas of the Congo to inculcate witch doctors with the slogan: "The Soviets are going to come and liberate Africa and return its old tribal chiefs and sorcerers. You have beer elected. When, with your support we have ousted the white oppressors, your ancient powers will return."69

In conversation with British officials at their Belgian embassy, the Canadian Ambassador discovered that the report had been written by a certain Captain Freddy, an individual of questionabie background. The British considered some parts of the story to be "utter nonsense" and discovered that it was not at all an official report of the Belgian government. L.H. Ausman, the Canadian Trade Commissioner in Leopoldville, also considered the news story "extremely inaccurate."70 Ausman was very moderate in his views. He acknowledged that some communist ideology had penetrated into the Congo, but that activities along the lines reported in Freddy's account simply did not happen. He noted that the local Belgian authorities took the communist threat seriously and had recently adopted measures to limit, as much as possible, the spread of communist ideals. A year later, W. Gibson-Smith, who succereded Ausman as Trade Commissioner, reported that the Commanding Cieneral of the Force Publique was unconcerned about the spread of

iX c.an Amb Bru to SSEA, 23 l.unuary 23 1950: N.A.C., RC25, Vol. 3270, File $\$ 6386-40$ p. I.

"" (an Amb Bru to SSEA, 23 January 1950: N.A.C., RCi25, Vol. 3270, File \$6386-40 pt. 1.

711 Ausman to USSF:A, 3 April 1950: N.A.C., RCi25, V'ol. 3270, File\#6386-40 pt. 1. 
communism amongst the Congolese because he considered the ideology to require more discipline than was to be found in the Natives. 71 In the early fifties, when political conditions were relatively calm and stable, (anadian officials believed that there was little need to be worried about communism in the Congo. Belgium took the threat more seriously, but even its officials remained relatively unconcerned until it became obvious that independence would need to be granted much earlier than anticipated. By June 1960), Canadian officials also acknowledged that the Eastern European countrie's could pose a serious threat if they became involved in the political development of an independent Congo.72

While the Congolese prepared for independence celebrations, the Canadian Cabinet discussed the possibility of upgrading (anadian representation in the Belgian Congo from a Trade Commission to a Consulate General. External Affairs regularly received copies of British Foreign Office reports on the Congo, and Canadian diplomats in Washington, the U.K. and Brussels forwarded other relevant information when possible. The only first hand source of intelligence, however, was from the (anadian Trade Commissioner in Leopoldville. In February of 1959, Norman Robertson, the Under-Secretary of State for External Affairs, had written to the Deputy Minister of Trade and Commerce to request that the l.copoldville Trade Commissioner be permitted to send occasional reports on the state of affairs in the Congo, when it would not interfere with his other I'rade and Commerce activities. 73 P'rior to this, it was not uncrimmon for the Irade

71 Gibson-Smith to Director, TCS, 25 Innuary 1951: N.A.C., RC:25, Vol. 3270, Iille \#f 3kh $40 \mathrm{pt} .1$.

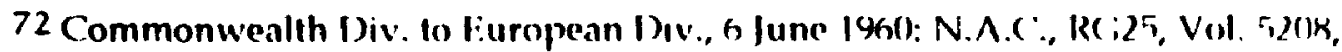
File $\# 6.386-40$ pt. 5 .

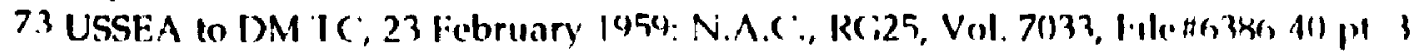


('ommissioner to do this on his own initiative, but following Robertson's request such reports arrived in Ottawa quite regularly.

In July 1959, the Canadian Embassy in Belgium put forward the suggestion that the Trade Commissioner in the Congo be given the title Consul-Cieneral, in light of the Belgian's colony's political importance and the likelihood that it would soon be independent. 74 This proposal initially received a cool reception at External. The Commonwealth Division stated its satisfaction with its current sources of intelligence on the Congo and felt that it might be unwise to "take an isolated plunge into the question in Black Africa." 75 They pondered the implications of increasing representation in the Congo, but not in French and Portuguese territories. The European Division also expressed the concern that an increase from Trade Commission to Consul-General might imply a tacit recognition of an independent Congo at a time when the Belgian government and Congolese leaders were still trying to negotiate the political future of the colony. They considered it better to let "sleeping dogs lie until a solution has been found to the political situation in the Congo."76 For the time being, the idea was shelved.

By March 1960, concerns that a change in diplomatic status might offend the Belgians were no longer applicable. The Belgian-Congolese Round Table Conference in January had settled on June of that year as an appropriate date for the Congo's independence. Norman Robertson put forward the idea once more. He argued that developments in the Congo would have "an important bearing" on the political evolution of surrounding African

74 c an Amb Bru to USSEA, 31 July 1959: N.A.C., RG25, Vol. 7034, File\#6386-B-40 pt. 1.

75 Commonwealth Div to Consular Div, 21 September 1959: N.A.C., RG25, Vol. 7034, Fill. $\$ 6,386 \mathrm{~B}-40 \mathrm{pt} .1$.

7n fiuropean Div to Personnel Div, 25 November 19.59: N.A.C., RG25, Vol. 7034,

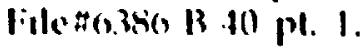


territories and noted the advantage of having first hand political reports from the area. 77 Concern for the safety of Canadians in the potentially unstable weeks that would follow independence was also an important factor.

Howard Green, Secretary of State for External Affairs, W'as unsure that Cabinet would approve the change, particularly if it was not clear that there would be trade advantages to doing so. The idea was set aside once again until June. At that time, Green agreed to take a joint proposal to ( abinet, together with Gordon Churchill, Minister of Trade and Commerce.78 The proposal met with some opposition, particularly once Treasury Board officials argued against it. They suggested that the cost was not warranted because ('ongolese officials had in the past recognised the Trade Commissioner as an official Canadian trade representative. Cabinet overruled these concerns, visions of greater wheat sales to a growing African market turning the decision-making tide. 79

In the weeks before independence, the Belgian Ambassador to (anada called upon Howard Green to see what, if any, assistance (anada could provide to a newly independent Congo. Prior to the meeting, officials at External prepared a memorandum, in which they surmised there would be a great need for material aid and technical guidance in the ('ongo. They argued, however, that Canada was not in a position of offer any assistance. ('andada provided no direct capital aid in Africa and technical assistance and scholarships were given only to countries within the (ommonwealth." Nevertheless, Green seems to have given the Belgian Ambassador the

77 Robertson to Green, 22 March 1960: N.A.C., RCi25, Vol. 70134, liile \#6 366 is 401 pt. 1.

78 Cabinet Document 167/60 and 196/60: N.A.C., RC; 2, Vol. 5937.

79 Cabinet Conclusions, June 30, 1960: N.A.C., RCi2, Vol. 2746.

80 Memo re: The Belgian (ongo, 10 March 1960): N.A.C., R(;25, Vol. 5206, 1.1le $\# 6356,40$ pt. 4. 
impression that some help might be expected from Canada.81 The Ambassador was especially interested in contributions to the field of education or technical assistance by French-speaking Canadians.

Canada was represented at the Congolese independence ceremonies by the (anadian Ambassador to Japan, who happened at the time to be visiting his son, the acting Canadian Trade Commissioner to the Belgian Congo. The ceremonies were held at the Palais de la Nation, the home of the Congo's first parliament, with representatives of 80 countries present. George Clay, a reporter for the London Observer, remarked:

Behind the long white building with its lofty lobbies and airy open stonework a green garden rolls down to the river's edge. But looked at closely, the noble palace is uncomfortably reminiscent of an insubstantial film set. Its drapes conceal gaps in the plasterwork, roughly breached walls and unfinished ceilings. Everywhere there is evidence of the haste with which the stage was set. 82

The setting seemed to disclose the state of affairs in the Congo all too well. Dag Hammarskjöld, the UN Secretary-General, had visited the Congo in January, 1960 and believed that the Congolese would need massive technical assistance following independence. To this end, Ralph J. Bunche, UN UnderSecretary for Special Political Affairs, was present at the independence ceremonies. Bunche was assigned the task of meeting with the new government to determine what UN support might be required. With the exception of a few tense moments, which followed Prime Minister Patrice l.umumba's anti-Belgian speech, the day passed without incident. The weeks and months ahead would be different.

8I Bel Amb Can to SSEA, 19 April 19, 1960: N.A.C., RG25, Vol. 5208, File\#6386-40 pt. 4. $\times 2$ George Clay, "Fntire Cabinet of the C'ongo lacks Single Day's Experience," Globe and Mloill|Torontol 30 lune 190: 7. 


\section{Chapter 2 \\ The Canadian Response}

Within a week, Patrice Lumumba's government was on the verge of collapse, and the new country was descending into anarchy. The rorce Publique, mutinied on 5 July in Leopoldville. Mutineers attacked Belgians and other Europeans, "and in some cases committed rape and other atrocities." 83 Congolese soldiers were upset by the continued presence of Belgians in the Force. Indeed, a Belgian, Lieutenant-Cieneral Emile Janssens, commanded the military and the officer corps remained exclusively Belgian. Congolese soldiers wanted greater opportunity for promotion and advancement, but Janssens was unwilling to compromise on this issuc. Ile believed little should change once the (ongo achieved independence, and was vocal about this.

On the day of the mutiny, Janssens wrote to the Prime Minister to admonish him for delivering "irresponsible speeches and announcements" that he believed had a demoralising effect upon the snidiers in the Force. I He warned, "As I am not in the habit either of changing my mind or of repeating myself, I would be grateful if you would take this as a final and solemn warning." Later in the day, Janssens met with Force officers and scrawled on the blackboard the words "before independence=after independence." 84 Janssens personified the disagreeable effects of Belgian colonialism, and it was his actions and words in the days that followed independence, far more than Lumumba's, that propelled Congolese members of the Iorce towards mutiny.

83 United Nations, Department of Public Information, The Blue l lelmets: A Review of United Nations Peace-keeping. ?nd ed. (New York: United Nations, 1990) 217.

84 Catherine Hoskyns, The Congo Since Independence: January 196(1-1)ecember 1961 (I.ondon: Oxford U P, 1965) 88. 
Janssens was typical of many Belgians who fully expected that little, if anything, would be changed by independence. In the days and weeks ahead, events demonstrated just cause for the new Congolese leaders to be suspicious of Belgian motives.

The mutiny quickly spread to other centres within the country and Europeans began to flee to neighbouring states. There was a mass exodus across the Congo River into Brazzaville. As the Europeans fled, the infrastructure and essential services fell into disarray. On 8 July, in consultation with the British Ambassador, the Acting Trade Commissioner, Roger Bull, decided to evacuat $\epsilon$ Lanadian women and children associated with the Trade Commission to Brazzaville and Belgium. Approximately 240 to 260 Canadians were present in the Congo, but the majority were missionaries who chose to remain until the situation worsened during the second week of July. Bull found that the situation in Leopoldville, relative to other regions of the country, remained calm. He reported:

The Leopoldville mutineers were undoubtedly rough, but there was no evidence that they either shot or severely injured anybody. Indeed, by dawn, one of their main reasons for stopping people was to plead with them not to run away... . Driving around in Leopoldville during the morning the mere statement that one was Canadian or English or at least not Flemish, was usually sufficient to avoid anything more serious than a cursory search of the car for arms at the road blocks. 85

In various locations outside the capital, as the mutiny widened, crises erupted. In the port city of Matadi, Europeans were held hostage and looting was rampant. In Luluabourg and the provincial capital of Katanga, Elisabethville, Europeans withdrew from rampaging mutineers. By 18 July 25,000 Belgians fled the Congo and their stories of violence were

\$5 Bull to USSEA, 4 August 1960: N.A.C., RG 25, Vol. 5209, File $\$ 6.386-40$ pt. 9. 
"considerably exaggerated" by the world press. Brian Urquhart noted that, from this point, the crisis took on "strong racial overtones ... (and) no amount of idealism, sincerity, or disinterestedness would keep the UN operation immune from them."8n Prime Minister Lumumba and President Kasavubu flew from location to location trying to quell the riots. Their absence from the capital made it more difficult to take concerted action. It was not until the 10th that the Congolese government accepted the advice of Bunche and Hammarskjold. Together they had formulated a plan to send to the ('ongo a team of technical assistance personnel capable of providing military advice to the new government.

The following day Belgium ordered its forces to enter the Congo to protect its civilians and interests. The Belgian paratroopers landed in Leopoldville, Matadi, Luluabourg and Elisabethville. This move by the Belgians added a new slant to an already complicated situation. The Belgian aim may simply have been to provide protection for Furopeans living in the Congo.87 There were certainly many Europeans resident there who hoped the Belgian government would intervene but to the Congolese the arrival of paratroopers seemed more like an attempt to reverse decolonisation. Belgian intervention resulted in a "deep suspicion and fear of whites in gencral on

86 Brian Urquhart and Ernest Lefever both suggest that the extent of violence in the Congo was exaggerated by the press. Brian Urquhart, Hammarskjold (New York: $\wedge l f$ red $\wedge$. Knopf, 1972) 402-403. Ernest W. Lefever, Crisis in the Congo (Washington I). ( $:$ The Brookıngs Institution, 1965) 6.

87 Ernest Lefever in, "The Limits of U.N. Intervention in the Third World" Ihe Review of Politics 30 (1968) and Wynfred Joshua in, "Belgium's Role in the UN Peacekeeping (operation in the Congo" Orbis 11.2 (1967), both cast Belgian intervention in a favourable light with a generally pro-Belgian interpretation of the crisis. L.efever argues that the Belgians intervened only to restore order and facilitate the departure of Furopeans who wanted to leave. Joshua suggests that Belgium had no intention of reimposing colonial rule. If this is the case, the Belgian government failed to appreciate the negative impact of their actions on international and Congolese perceptions oi their motives. 
the part of the Congolese population." 8 skirmishes between Belgian and (ongolese forces occurred throughout the country and in Katanga the provincial president, Moise Tshombe, declared independence. The secession had serious implications. The viability of the entire country was placed in question once its richest province declared its intention to leave the federation. Katanga's many economic and political connections with Belgium also cast a larger shadow of doubt upon the motives behind its intervention.

Roger Bull was very critical of Belgium. He considered the invasion of l,eopoldville "unnecessary" and suggested that Belgian policy was, "illconceived, ill-executed and, in the deepest sense, irresponsible. . . Popular opinion among Europeans here is that the Belgian government has been cowardly, vacillating and stupid." He also noted that Belgian military officers were inconsistent in their interpretation and application of the premise on which their intervention was based. Bull said of General Cumont, sent by Belgian authorities to take command of its military forces in the Congo, that he knew "little about the Congo and cares even less for the welfare of its citizens. He has binaved throughout in a childish and vindictive manner... treating army intervention as an exercise." He concluded that the Belgian invasion "completely obliterated any element of black/ white cooperation or sympathy in the Congo. A most unpleasant xenophobia is now present" 89

Aside from Belgium's NATO allies, the international community was virtually unanimous in condemning its actions in the Congo. The Soviet bloc was quick to exploit the situation, calling it an act of Western colonial imperialism. On 12 July, Lumumba and Kasavubu cabled the Secretary-

88 Brian Urquhart, Hammarskjold (New York: Alfred A. Knopf, 1972), 404.

84 Bull to USSEA 4 August 1960): N.A.C., RLi 25, Vol. 5209, File $\$ 6386-40$ pt. 9 and R.A. Bull I) (i.li.C. Hughes, I August 1\%60): N.A.C., RGi25, Vol. 7034, File \$6386-B-40 pt. 1. 
General requesting UN military assistance; they emphasised that this aid was "to protect the national territory of the Congo against the present external aggression which is a threat to international peace." 40 The congolese hoped not only for UN technical assistance to restore internal order, but also for a large-scale UN military intervention that would protect congoleso interests in the face of Belgian aggression.

In Canada, the Congo crisis made headlines. The Clobe and Mail followed the situation for weeks, usually printing front page stories. 'The editorial pages were also filled with commentaries calling for UN action. ( $n$ 12 July The Globe asked "Where Are the UN Police?" in an editorial that was essentially pro-Belgian, yet called for the dispatch of a UN armed force. In the House of Commons, the issue was raised by the opposition. Paul Martin asked the Diefenbaker government if it intended, "to inform the secretary general of the United Nations that if United Nations police forces are required and requested for the preservation of order in the new ('ongo state, a Canadian contingent is ready, trained and available to be moved by air transport immediately." 91 Diefenbaker was evasive in his response, noting that t'ie Secretary-General was consulting with the African nations, and that he thought it was premature to offer assistance until these consultations were completed.

Officials in the Department of External Affairs busily formulated policy options as they maintained close contact with the (anadian Permanent Representative to the United Nations, Charles Ritchie, and also with diplomatic posts in Belgium, the United States and the United Kingdom. By

90 United Nations, The Blue Helmets, 2nd ed. (New York: Uniled Nolfon', 1)epirtinent of Public Information, 1990) 218.

y1 Canada, House of Commons Debates, 12 July 1960: 61111. 
13 July, Ritchie had discovered that the telegram sent to Hammarskjöld by l.umumba and Kasavubu specifically requested troops from "neutral" nations. Thus, Ritchie was led to believe that troops of NATO countries (including ('anada) would not be asked to take part in the Congo force.92 This perception changed, however, after Hammarskjöld revealed his plans to resolve the Congo dilemma at a luncheon for members of the Security ('ouncil.

The Secretary-General suggested a three-pronged approach to solve the international crisis. First, he believed that Lumumba's initial request for military, technical assistance was a long term project thac could be met by seconding French-speaking officers from the United Nations Truce Supervisory Organization (UNTSO) in Palestine. Second, althongh Hammarskjöld initially thought that it was unwise for the $\mathrm{UN}$ to intervene militarily on a large scale, Bunche supported this option as conditions in the Congo deteriorated and the Secretary-General was willing to concur with the recommendations of the Under-Secretary. Third, Hammarskjöld identified an urgent need for supplies and food aid.

The Secretary-General did not discuss the composition of the large imce ai iine luncheon, but Ritchie was aware that the Secretariat was considering the use of furces from Asia, Africa and "trans-Atlantic French"ipraking surcess." The latter nas presumed to be an allusion to either Haiti or ('andada. Because the Congo had been a Belgian colony, French was communiy unedi. ivonetheless, at first Ritchie considered it unlikely that Callada would be asked to provide a contingent to the proposed force. iensusatiy, in beiieved "that white troops of any kind would be in a very

42 Robertson to Cireen, 13 luly 19601: N. A.C., RC25, Vol. 5208, File $\$ 6386.40$ pt. 6. 
difficult situation, especially if required to fire upon the ('ongolese mutineers or the population." He also assumed that the Canadian standby battalion was not suitable for service in this larger UN force. ${ }^{4.3}$

Later on the 13th the Under-Secretary of State for I:xternal Affairs, Norman Robertson, prepared a memorandum for the Minister that provided details on all three of Hammarskjöld's proposed actions, in anticipation that a formal request from the UN would be forthcoming. Fxternal Affairs consulted with the Department of National Defence and determined that there was no military reason why Canada should not respond favourably if the Secretary-General requested the secondment of French-speaking ( anadian officers serving in UNTSO. Nor did he see any political reason, although there would be considerable personal risk for white officers serving in the Congo. 94

Robertson was cautious on the question of Canadian participation in the Secretary-General's proposed UN peace force for the (ongo. Because the force would be assigned the task of restoring order, he assumed that it might become necessary for peacekeepers to fire upon Congolese mutineers or even rowdy civilians. He remarked, "It is difficult to see any United Nations force in this role because in effect the United Nations would have taken up arms against citizens of a state in what was essentially a domestic situation." 45 I le sensed, however, that the Secretary-General's reference to a 'trans-Atlantic French-speaking' country was intended to suggest ('anada. I Io anticipated that Hammarskjöld would have a difficult time locating forces that were c.,$\ldots$. of providing logistic support to a mixed force, particularly given the problems

93 G.S. Murray, 13 July 1960: N.A.C., RC;25, Vol. 5206, File $\$ 63866-40$ p1. 6.

94 Robertson to Cireen 13 July 1960: N.A.C . RC.25, Vol. 52118, lille 46364,411 pt. 6.

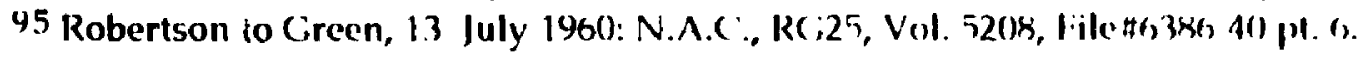


posed by differences in language. He concluded:

I believe that any white troops involved in the proposed law enforcement role of the United Nations would be in a most difficult situation, since it would be difficult to persuade the Congolese masses that the United Nations force was not another form of white domination. The administrative units of the force might not be required to coerce the Congolese in any way but they might have to protect themselves and the supplies and equipment of the force against Congolese attack. On balance, therefore, we should have to look very carefully at any request involving a Canadian contingent for the force and the SecretaryGeneral should be made aware of our hesitation to become involved in this way. 96

Robertson's recommendation was a far cry from the Opposition's eager suggestion, put forward in parliament just the day before, that Canada should approach the UN to offer the services of its standby battalion.

Robertson did recommend that the Cabinet consider the provision of foodstuffs or supplies, and the necessary air transportation to move these gifts to the Congo, to alleviate serious food shortages. He noted also that the UN had informally requested the use of two Canadian aircraft serving in UNEF, for the purpose of ferrying supplies and personnel to the Congo. The RCAF saw no objection to such service, and so Robertson suggested that Canada agree to provide the aircraft if the UN formally requested their use.97

Because Howard Green was away from Ottawa at a joint conference of U.S. and Canadian Ministers on defence matters, the Prime Minister reviewed the Congo file himself. Basil Robinson, Diefenbaker's special assistant on foreign affairs, reported that the Prime Minister, "shot out of his chair and told me to see that Hammarskjöld was told right away not to

\footnotetext{
46 Robertson to (ireen, 13 July 1960: N.A.C., RCi25, Vol. 5208, File $\$ 6386-40$ pt. 6.

47 Robertson to (ireen, 1.3 July 1960: N.A.C., RG25, Vol. 5208, File $\$ 6386-40$ pt. 6. 
proceed with the idea of troops from Canada." 48 Robinson reported Diefenbaker's views to the Under-Secretary at once, advising Robertson that the temporary secondment of (anadian officers in UNTS() would likely be approved by the Cabinet and that serious consideration would be given to any UN requests for foodstuffs. The question of a Canadian contribution to the large peace force, on the other hand, was a different matter. Robinson advised that,

The Secretary-General should be told immediately not to make any mention to representatives of other countries of the possibility of a military contribution from 'a trans-Atlantic French-speaking country'. The Prime Minister was emphatic that he did not wish any expectation to be aroused that military assistance from Canada would be forthcoming. ${ }^{49}$

The Cabinet met the following day, and Diefenbaker informed them of the action he had taken. Cabinet noted the Prime Minister's decision, but no discussion of the matter seems to have taken place.100 Thus, the earliest Canadian response to the possibility of $\mathrm{UN}$ service was hesitant.

Diefenbaker continued his evasive parliamentary tactics to avoid openly confronting the issue of Canadian participation in UNCX. In a question about Canada's role in the Congo crisis, Hazen Argue (M.P. for Assiniboia), alluded to Canadian popular support for peacekeeping activities. He asked:

In view of the well known interest of Canadian citizens in our country being of every possible assistance in these difficult times, has the Canadian government given any consideration to making an offer of needed technical and professional personnel, preferably through the United Nations, for use in the Congo?101

98 H. Basil Robinson, Diefenbaker's World: A Populist in Foreign Affairs (Toronto: (1) of Toronto P, 1989): 148.

99 Memorandum from the Office of the Secretary of Stale for Lixternal Affairs, 13 fuly 1960: N.A.C., RG25, Vol. 5208, File $\$ 6386-40$ pt. 6 , .

100 Cabinet Conclusions, 14 July 1960), paras. 4-5: N.A.C '., RC:2, Vol. 2747.

101 Canada, House of Commons I) bates, 13 luly 1960):6179. 
Diefenbaker somewhat muddled the issue when he suggested in his response that Argue was thinking of the Secretary-General's technical assistance program, and that Hammarskjöld was interested first in drawing personnel for this mission from the African states. The P'rime Minister's response was inaccurate because Hammarskjöld planned to use African and Asian forces primarily for the larger peace force, and fully expected that he would need to use personnel from non-African and non-Asian count:ies, who had some peacekeeping experience, for the smaller technical assistance program.

Diefenbaker then confused matters further when he mentioned that officers might be seconded from UNTSO for this purpose, once permission from the ('anadian government was granted. The Prime Minister's response did little, in the end, to clarify Canada's role. The Globe and Mail could almost be excused for printing a story that in one paragraph made the sweeping statement that "Canada is prepared to fill any United Nations appeal for police troops for service in the Congo," but that two paragraphs later stated, “('anada hopes no request will come from UN Secretary-General Dag Ilammarskjold for the battalion of troops which this country maintains on a 24-hour alert for such international police action."112 It seemed to be a case of 'peacekeeping if necessary, but not necessarily peacekeeping'.

( )n the evening of July 13th/14th, the UN Security Council convened to consider the Congo situation, at the request of the Secretary-General. Until this time, Hammarskjöld had attempted to deal with the crisis within the office of the Secretary-General, so as to insulate the UN's response to the crisis from superpower politics. Once it became clear that more than a technical assistance program would be necessary, and that a major peacekeeping force 1.

112 "C anada to Aid Congo Only if UN in charge," Globe and Mail ITorontol 13 July 1960, 
would be required, he used his authority under Article 99 to convene a meeting of the Security Council.103 It approved Hammarskjöld's plan to establish the United Nations Operation in the Congo to restore and maintain law and order until, with the aid of UN technical assistance, ('ongolese armed forces were able to fulfil this role on their own. A Soviet amendment to the resolution, which would have exclusively restricted the composition of UNOC to African states, was barely defeated (5 against-China, France, Italy, UK, USA; 4 in favour-Ceylon, Poland, Tunisia, USSR; 2 abstentions-Argentina, Ecuador). As part of UNOC's enabling resolution, the Council also called upon Belgium to withdraw its forces from Congolese territory.104 Soviet attempts to have Belgium condemned for aggression against the Congo were voted down. In the end, the issue of whether cor not Belgium had committed an act of aggression was deliberately sidestepped. In fact, resolution 143(1960) was remarkably vague in its terms and in a sense needed to be in order to compensate for the new peacekeeping challenges posed by the Congo. As Lefever states, "There were no demilitarised zones, no truce lines, and no peace for the peacekeepers to keep." $105 \mathrm{UNOC}$ was going to be a very different creature than UNEF, and this became painfully obvious in the weeks and months ahead.

Before the Council session, ('harles Ritchie met with Hammarskjöld to discuss the Secretary-General's plans. Earlier, External Affairs contacted Ritchie and requested that he speak to I lammarskjöld and express clearly the

103 Article 99: "The Secretary-General may bring to the attention of the Security Council any matter which in his opinion may threaten the maintenance of international peace and security." This provision in the UN charler was used for the first time during the (ongo) crisis.

114 Security Council resolution 143(1960) is reproduced in Appendix 1.

105 Ernest Lefever, "The Limits of U.N. Intervention in the Ihird World," The Revirw of Politics 30 (1968): 4. 
Canadian government's reluctance to become involved in the larger peacekeeping force that was being contemplated. While mixed signals may have bees: given in Ottawa, the Canadian position was enunciated clearly and frequently in New York. The Secretary-General confirmed that he intended to approach (ieneral von Horn (Chief of Staff in Jerusalem) to see if a number of French-speaking officers could be spared from UNTSO for the technical assistance program. He expected that this would involve both Canadians and Scandinavians.

The larger peacekeeping force was to evolve in two stages. In the first stage, contingents from African states would be used to develop an atmosphere of confidence by demonstrating to the Congolese that the UN presence was designed to help maintain their independence. He suggested that it would be desirable to include non-African forces only after the first stage had been accomplished. The Secretary-General added that "at the present time, however, there was no question of any request for a Canadian contingent. Press reports suggesting that the Secretary-General was looking to Canada for a contingent were entirely inaccurate and misleading." 106

The following morning Hammarskjöld and Ritchie spoke again. By this time, the Canadian Representative had received yet another telegram frum External Affairs exhorting him to discourage further any request for military assistance from the UN Secretariat. Ritchie once again expressed the

\footnotetext{
I1)n Robertson to Green, 14 July 1960: N.A.C., RC25, Vol. 5208, File\#6386-40 pt. 6. J.L. iranatstein in, "Canada: Peacekeeper," Peacekeeping: International Challenge and Canadian Response (Lindsay: Canadian Institute for International Affairs, 1968): 155-156, refers to Mttawa dispatches that reported Bunche in Leopoldville saying Canada would be expected to send paratroopers. He notes that the government doubted the accuracy of the reports, in response to calls for action in the conservative press. It turns out that the news stories were based on a 'leaked' private conversation between General Alexander and Bunche, in which they only theoretically discussed the possibility of using bilingual paratroopers for rescue operations. Thus, the reports were inaccurate.
} 
government's concern. Hammarskjöld emphatically stated that the question did not even arise because offers of troops from African nations were more than sufficient to staff the force. He did take the opportunity, however, to request the secondment of two (anadian officers from UNTSO for the technical assistance program. 107

In Ottawa, both Diefenbaker and Howard Green addressed the issue of the Congo in statements made in the House of Commons on July 14, 1960). Diefenbaker's speech was the clearest public pronouncement on the government's policy to that date. He argued that it was his view that peacekeepers for a major UN force should be drawn primarily from neighbouring African states to avoid any misapprehension, on the part of the Congolese, that might otherwise result from the use of non-African forces. 1 le stated that the government would look favourably upon requests for technical advisors, food or transportation and concluded:

The government is responding favourably to requests of this kind because it believes that this is the most useful contribution which Canada can make in the current situation. If there are additional requests of the same nature they will be considered seriously. 108

Lester Pearson, Leader of the Opposition, agreed with the government's policy and actions, but suggested that, if sufficient forces could not be mustered by the UN relying on African states alone, perhaps the government could "let the United Nations know that we have a battalion trained, equipped and available for that kind of service that could be made available if it were required by the United Nations." 104 In a speech delivered later that same day, Howard Green also addressed the issue of Canada's role as peacekeeper. Ile

107 Robertson to Green, 14 July 1960: N.A.C., RC:25, Vol. 5206, Iiile \$63\$6-41) p1. 6.

108 Canada, House of Commons Debales, July 14, 1960: 6273.

104 Canada, House of Commons Debates July 14, 1960: 6273-4. 
said:

We are continuing to be greatly interested in the peace-keeping machinery of the United nations. Canada already plays as big a part as any other nation in the peace-keeping arrangements of the United Nations and the government is continuing that policy. It may be that some provision will have to be made for further support for the United Nations in this field. Certainly our minds are not closed and we are very much in favour of doing everything that Canada can do that is practical to help strengthen the peace-keeping machinery of the United Nations.: 10

As these speeches were being given in Ottawa, Canadian rupresentatives at the United Nations were carrying out their instructions to limit and/or head off requests for peacekeeping assistance. In addition to Diefenbaker's racial concerns that white, french-speaking peacekeepers might be placed in a particularly dangerous position, there were also financial and logistic considerations. Granatstein writes,

Canada's armed forces were expensive enough already, and the recent decision to saddle the army with the major share of responsibility for the National Survival program had stretched manpower to the limit; and finally, the state of the Canadian economy was disquieting enough that new expenditures were regarded unhappily by the Treasury Board.111

Diefenbaker's and Green's speeches undoubtedly demonstrate the government's sensitivity to the political implications of support for UN peacekeeping activities. They felt compelled to support peacekeeping publicly, even as they were quietly limiting the potential for future cornmitments in the (ongo.

Because the Great Powers were usually prevented from playing anything more than a supporting role, participation in peacekeeping fell

110 Canada, House of Commons Debates, 14 July 1960: 6296.

111 J.l. Ciranatstein, "Canada: Peaceleeper," Peacekeeping: International Challenge snd Canadian Response (I.Indsay: Canadian Institute for International Affairs, 1968): 153-154. 
primarily upon the middle powers. Thus, Canada played a useful role in its support of UN peacekeeping missions. An editorial from 14 July 1960 in the Globe and Mail demonstrates the perceived importance of peacekeeping to

Canada at the time of the Congo crisis:

Prime Minister Diefenbaker was asked in the Commons this week if he has offered this battalion to the UN for use in the Congo. He replied that the UN Secretary-General, Mr. Dag Hammarskjold, had the Congo crisis under advisement; the question of Canadian assistance, military or otherwise, would not arise until Mr. Hammarskjold made a specific request to Canada.

This is too passive, too negative, Canada should be playing an active, positive role on the side of peace. How better, at this time, could we play such a role than by helping to bring peace to the Congo? What greater contribution could we make to the world than by helping to put out flames which could spread through Africa? We have poured, still are pouring, billions of dollars into defense. This money would be more usefully spent on organizing a permanent Middle-Power police force than on maintaining our present subservient role in the North American Air Defense system. ...

With like-minded countries, we could build a force that would clear up trouble-spots, removing them from the area where they give the Great Powers an excuse to rattle rockets at one another.

In the Congo today, the blood of Africans and Furopeans is being spilled. If Canada stands for peace, this is Canada's business. As the darkness gathers in Africa, ('anada should not be waiting to find out what, if anything, is expected of it by Mr. Hammarskjold. Canada should be stating clearly its will and wish to join other peaceful nations in going to $\Lambda$ frica and restoring the peace. 112

The Diefenbaker government did not want to answer this call to restore peace in Central Africa. Diefenbaker himself would later write, "As Prime Minister, I believed that Canada should take an appropriate part in United Nations peacekeeping activities. But I never thought that this should be automatic; I think the idea ridiculous that Canada should perforce participate in every

112 "Canada's Defense Duty," The Cilobe and Mail |T orontol I4 July 146(1): 6. 
United Nations peacekeeping activity." 113 Nonetheless, he was certainly aware of the political importance of participation in UN peacekeeping; in all probability, this influenced Diefenbaker's Congo policy.

During the evening of 14 July, the NATO Council was called to a special meeting, at the request of the Belgian representative. Belgium attempted to rally support for its position in the Congo. Prior to independence, a treaty of friendship had been negotiated between Belgium and the Congo which provided Belgium with two permanent military bases. The Belgians wanted to retain these installations after they withdrew their forces, as they were required to do by the UN Security Council. They appealed to their NATO allies to support them on this issue. Belgium reminded the Western powers of the Congo's strategic importance, in terms of both geography and mineral resources. The Canadian representative, Jules Léger, was surprised by the Belgian assessment of events in the Congo. Belgian officials thought that the actions of the Congolese authorities were being orchestrated by communist sources outside the Congo.114

léger may have been surprised to hear that communists were behind the Congo crisis, but not officials at External. In Ottawa, the possible involvement of communist provocateurs had been a topic of great and recent interest. From Pretoria the Department learned that the South African Consul-General in Leopoldville, Mr. Hewitson, saw little evidence that communists had helped to bring about the collapse of the Congolese authorities. He did, however, think it quite probable that some Belgian communists in the Congo would take advantage of the anarchy there.115 In

113 John G. Dief anbaker, One Canada, 3 vols. (Toronto: Macmillan of Canada, 1975, 1976, 1977) 2: 129.

114 NATOPARIS To External: N.A.C., RG25, Vol. 5208, File\#6386-40 pt.6.

115 I'RETUORIA To External: N.A.C., RG25, Vol. 5208, File\#6386-40 pt. 6. 
Washington, the African Affairs Bureau was also studying the question of communist infiltration. Mr. Hennemeyer, of the West African Desk in the State Department, shared the American analysi:i with a number of diplomats, including staff from the Canadian Embassy. Hennemeyer said that American officials were puzzled by the nature of the operations of the Force Publique's mutinous elements. They had expected the mutineers to participate in indiscriminate looting, other disorderly conduct and the selfish acquisition of food and other valuable commodities. Instead, they seized control of municipal offices, telegraphic services and air strips. State Department officials discerned a pattern in these circumstances that implied either internal or external guidance of the mutiny, "based on highly sophisticated ideas about guerrilla activities that could probably have been gained only through contact with communist organizations bent on fomenting trouble in the Congo."11n In spite of this rather sinister appraisal of the mutiny, the State Department concluded that there was little likelihood of serious communist inspiration. In fact, the Deputy Assistant Secretary for African Affairs argued that the Belgian military authorities were simply using the "spectre of communism" to rally support for their position. 117

Although little evidence einerged to either confirm or reject the possibility that communist agents may have played a role in the instigation of the Congo crisis, the Cold War implications of anarchy in the Congo were obvious to all and influenced both public perceptions of the crisis and policy making. For example, Canada was reluctant to support publicly Belgian claims to Congolese military bases because this might "give substance to charges of Western aggression ... [and] would seem calculated to create the

116 WASHDC to External 1817: N.A.C., RC;25, Vol. 5208, File\#6386-40 pt. 6.

117 WASHDC to Fxternal 1825: N.A.C.., RC25, Vol. 5208, File $\# 6386.40$ pt. 6. 
worst possible impression among African and anti-colonial powers generally." 118 In addition, Prime Minister Lumumba and President Kasavubu exploited Cold War tensions, by publicly appealing to Khrushchev to intervene if the Western countries did not stop the 'Belgian aggression' against their country, as a means of expediting UN action. Khrushchev's threat to take "decisive measures to stop the aggression" was not well received in Canada. 119 In an editorial entitled, 'Mr. K. Brinksman,' The Globe and Mail soundly criticised Khrushchev for making a bad situation worse by promising military support, "to every country or faction which is involved in trouble with any of the Western Powers, however remote the scene of action may be from Russia and its normal concerns."120 Editorial cartoons appearing in the Globe on 19 and 23 July clearly portrayed a sinister side to Soviet motives.

Granatstein contends that public pressure ultimately forced the Diefenbaker government to increase Canada's contribution to the UN efforts in the Congo, and that this public pressure sprung from a simple desire to fulfil our national self-image. He states that "None of the usual triggers for public response were there;" and suggests as an example that "until a few months after the UN decision there were not even any Communists suspected of trying to unsurp [sic] the government."121

Public opinion undoubtedly shaped Diefenbaker's policy, as discussed previously, but public opinion was not fashioned by national self-image

118 External to BRUSSELS: N.A.C., RC25, Vol. 5208. File $\$ 6386-40$ pt. 6.

114 "Soviet Issues Warning," The Globe and Mail [Toronto] 16 July 1960: 1.

120 "Mr. K., Brinksman," The Globe and Mail (Torontol 16 July 1960:6.

121 J.L. Granatstein, "Canada and Peacekeeping: Myth and Reality," The Caradian Forum 54.263 (1974): 280; J.L. Granatstein, "Peacekeeping: Did Canada Make a Difference? And What Difference Did Peacekeeping Make to Canada?" Making a Difference? Eds. John English and Norman Hillmer (Toronto: Lester Publishing Limiled, 1992) 229. 
alone, as Granatstein contends. Canadian officials, as well as the public, were concerned that communists mipht indeed capitalise on the chaotic situation in the Congo. Stephen Weissman xamined American foreign policy in the Congo crisis and concluded,

Such uses of history |recalling Soviet exploitation of chaos in: Eastern Europe, Greece, etc.l, supplemented by inexperience in Africa, could lead to the darkest imaginings. Some fe.red that instability in the Congo would spread beyond its borders, creating golden opportunities for the Soviet bloc. All were concerned that a Communist victory in this large, centrally located state could create a base for the subversion of ('entral Africa. 122

While one cannot always apply conclusions made about the attitudes of American officials to their Canadian counterparts, in the case of the ('ongo) crisis it is possible to do so. On the issue of communist penetration, (anadian and American officials were clear-minded enough not to believe the almost paranoid ravings of the Belgians. They made an important distinction: the crisis was not perceived as communist hatched; they did see, however, the potential for communists to exploit chaos in the Congo. As if to reinforce these fears, on 14 July Kasavubu and Lumumba severed diplomatic rolations with $\mathrm{Be}^{\circ}$,um and sent a telegram to Khrushchev asking him to monitor the situation carefully in the event they felt it necessary to ask the Soviets to intervene.123 It is significant that Diefenbaker provided an account of UNCX in his memoirs as an example of how his government "was concerned and did its part to ensure that the African continent should not become the focus of the East-West struggle."124

122 Stephen R. Weissman, American Foreign Policy in the Congo, 1960)-1964 (Ithaca: Cornell U P, 1974) 53.

123 Catherine Hoskyns, The Congo Since Independence: January 1960-1) lecember 1961 (London: Oxford U P, 1965) 127-128.

124 John G. Diefenbaker, One Canada, 3 vois. Cloronto: Macmillan of ( anadia, 19\%7, 1976, 1977) 2: 126. 
The UN provided Diefenbaker with another opportunity on 15 July to demonstrate just how willing (anada was to do its part in the Congo. Although ( harles Ritchie repeatedly advised UN officials numerous times over the previous two days that (anada did not want to be asked to contribute furces to the military operation in the Congo, the Canadian Representative was approached by the UN on the afternoon of the 15th to do just that. Rit-hie was told that the UN was organizing a force that was tu consist of primarily African countries. The L.S.A. was contributing communications and logistics equipment and the LN hoped to employ technical personnel, Irom the Scandinavia. countries and Canada, to service the equipment. From Canada, the UN specifically needed signals personnel and equipment, in roughly the same proportion as had been provided for LNEF, as well as quartermaster and maintenance personnel.125 At this point, the Secretary(ieneral's request for Canadian signals and logistics specialists was not official but 'exploratory'. Specifics could not be worked out until the new UN ('ommander of LNOC, General von Horn, had surveyed the situation. Ritchie reported to Ottawa that he reminded the $\mathrm{UN}$ of the Canadian position with respect to the provision of military assistance and emphasised that the government did not consider it appropriate to contribute troops to the UN force. If offered, nonetheless, to transmit the Secretary-General's appeal.126

Basil Robinson was informed of the LiX's need for Canadian peacekeepers in the early afternoon. He sent a memorandum to Diefenbaker outlining the new requests made by the Secretary-General. In addition to the

125 Although the Li does not seem to havis said 50 in its communications with Ritchie, Rrian L'ryuhart mantains that Canada was the "soie wailable source of trained sigllaileis and communications units which could work in both Fingich and French," and that "It was for this compelling reason that Cana :ian units had been in.luded in the force." Brian Urquhart. Hammarshold (New York: Alfred A. Knnpf, 1972) 433.

I2n PI:RMISSY Io Futernal 94.3 \& 944: N.A.C.. RC;25. Vol. 5205, File $\$ 6386-40$ pt. 6. 
potentially controversial logistics and signals units, the UN asked that the government approve the secondment of three more officers from LNIS(). The Secretariat also requested assistance in the form of foodstuffs - flour, canned pork and dried milk as well as the necessary air transportation to send the supplies to the Congo. Robinson pencilled some notes on the bottom of the memorandum to emphasise that a contribution of logistics and signals personnel would be for the military force, and not for the technical aid program. When he saw Diefenbaker later in the day, the Prime Minister approved the secondment of two of the three officers in question and indicated that the remaining requests would need to be raised in ('abinet the next day. Robinson orally reiterated the significance of the request for communication and logistics experts, and while Diefenbaker did not give a positive reaction, his assistant was left "with the impression that his Inclination might be to respond favourably if a specific request were received."127 Diefenbaker was reluctant to agree to the $\mathrm{L} N$ request in principle because he thought this might be perceived in New York as "a blanket commitment to supply technicians."12k

The LN, however, was not in a position at that time to provide Diefenbaker with the specific details that he thought were needed. Because of mechanical difficulties with a number of planes sent to transport von Horn, LNOC's newly appointed Commander did not arrive in the ('ongo until is July.124 Only he would be in a position to give New York precise details on the sort of technical military assistance required. In the meantime, from Vew

127 Memorandum re: Assistance for Congo, 15 July 1960: V.A.C ., R(:25, V'ol. 521)\%, File $\$ 6386-40$ pt. 6.

$12 \times$ J.L. Granatstein “Canada: Peaceheeper," Peacekeepung: Internatunal ! hallenge" and Canadian Response (Lindsay: Canadian Instilute for International Affairs, I966) I5.

129 Carl von Horn, Soldiering for Peace (l,ondon: (assell, 1\%(6) 131136 
York, UN officials could phrase exploratory requests for assistance solely in the most general of terms.

The (abinet met on 16 July and considered the recent UN requests, just as the first peacekeepers began to arrive in the Congo. The secondment of two more UN'IS() officers as technical advisors to the Congolese government was approved. The guvernment also agreed to provide 20,000 pounds each of canned pork and whole milk powder, but only after considerable debate. Some Cabinet Ministers wondered if the aid might not be perceived by the public as a gift to "revolutionaries, rapists, looters, etc." Others expressed the view that surplus food supplies should be distributed as a priority to the ('anadian unemployed, rather than as international aid. In the end, the Cabinet decided to send the supplies. Given that India had also provided gifts of food, an act of charity it could barely afford, it would have subsequently proved embarrassing if the Canadian government had turned down this request. $A$ decision on $U N O C$ logistics and signals personnel was postponed, pending furtiner examination by the Department of National Defence.130 The following day, the Permanent Mission in New York reported that the Secretary-General requested battalions from Sweden, Yugoslavia and Ireland to be added to the contingents already present in the Congo. With the use of non-African forces, Hammarskjöld launched the second phase of UNC $($. ( )riginally, he had considered a combined Scandinavian contingent that would include forces from Denmark, Norway and Sweden. The final decision to ask for an exclusively Swedish force was construed by Canadian diplomats to mean that NATO powers would not be asked to contribute combat forces. The Secretariat, nevertheless, remained anxious for a reply to

130 Cabinet Conclusions, 16 luly, 1960): N.A.C., RG,2, Vol, 2747. 64. 
their appeal for Canadian peacekeepers, particularly French speaking signals personnel.131 The tempo of the Congo crisis had been increased by an ultimatum from Lumumba and K.asavubu. They wanted a complete withdrawal of Belgian forces within 48 hours. If this was not achieved, they threatened to turn to the Soviets for military assistance.132

In Ottawa, the Department of National Defence was preparing a survey, which examined the effects on domestic commitments of the withdrawal of signals personnel, for the Cabinet meeting scheduled on 19 July. The ('hief of the General Staff, after studying the situation, was reluctant to allow any sizable withdrawal of signallers for Congo service because of the difficulty involved in separating personnel without causing widespread disruption to othe: defence responsibilities.133 The army was in the process of training additional signals personnel, "but the demands of the National Survival plan, NATO, UNEF, and other regular commitments were outstripping the production of trained signallers." Defence officials believed that the withdrawal of any more than 150 signallers would disrupt their ongoing operations. 134

When Cabinet met on the 19th, it learned that the Secretary-Cienerai had inquired urgently the day before to see if a decision regarding his recjuest would be forthcoming. While awaiting a Canadian decision, the SecretaryGeneral asked the Tunisian government to temporarily provide a small signals detachment. The Department of External Affairs had already asked

131 Robertson to Green, 18 July 1960: N.A.C., RC;25, Vol. 5208, File\#6386-40 p1. 7.

132 United Nations, The Blue Helmets, 2nd ed. (New York: Uniled Nations Department of Public Information, 1990) 224.

133 Robertson to Green, 19 July 1960: N.A.C., RC;25, Vol. 5208, File $\# 6386.41)$ pt. 7. 134 J.L. Granatstein "Canada: Peacekeeper," Peacekeeping: Internalional ( hallenge and Canadian Response (Lindsay: (anadian Institute for International Affairs, 196\%) 155 and Robertson to Green, 19 July 1960: N.A.C., RC;25, Vol. 5219, File \#6386. (' 40 pt. 1. 
I lammarskjöld for a more detailed assessment of the UN's needs, and the Secretariat had urgently forwarded this task to General von Horn once he arrived in Leopoldville. Until the Cabinet received a specific list of von Horn's needs, the Minister of National Defence, George Pearkes, thought that there was insufficient information upon which to base a decision. Pearkes also advised Cabinet of the need to inoculate personnel against tropical diseases, a process that in itself would take three weeks. Canadian peacekeepers in UNEF had already been inoculated for tropical service, but because they were responsible for most communications in this force, it was not possible to transfer them to the Congo, even temporarily. The Cabinet was also asked to consider what help, if any, Canada could supply to assist the $\mathrm{UN}$ in its airlift of supplies for the Force and other UN agencies operating in the Congo. Supplies were accumulating in a staging area established at Pisa and needed to be transported to Leopoldville. Four Canadian aircraft that were used to transport the Canadian gift of foodstuffs were in the area, and the Minister of National Defence had determined that the cost would be $\$ 9,000$ per day, per aircraft. The Cabinet once again deferred a decision until more complete information could be obtained from the UN 135

Over the next two days, officials from External Affairs communicated with the Secretariat, through the Permanent Mission in New York. Further details regarding the Pisa-Leopoldville airlift were obtained. The UN envisioned an airlift shared equally between Italy and Canada. The arrangement was for $\mathbf{3 0}$ days, and the cost of the operation was to be reimbursed by the UN. It was made clear that this airlift was to provide logistic support for UNOC, and was not at all related to the transport of gifts of

\footnotetext{
T1.5 Cabinet Conclusions, 19 july 1960: N.A.C., RC2, Vol. 2747; Cabinet Document 228/nll: N. I.C., RCi2, Vol. 59.37.
} 
supplies and foodstuffs. The Assistant Trade Commissioner in Leopoldville had also wired Ottawa requesting that the government consider authorising the aircraft to land at points within the Congo, in addition to Leopoldville. Unfortunately, few specifics could be discovered about the logistic and signals requirements needed for the Force. Previously, a commitment comparable in size to the Canadian UNEF contingent was envisioned. After further discussions with the Secretariat, it became clear that, because UNOC would be deployed over a wider area, it might involve a larger commitment and would require heavy equipment that could not be transported from Canada in the existing RCAF aircraft.13n

At the 21 July meeting of Cabinet, Howard Green recommended that Cabinet assign four North Star aircraft and their crews to the PisaLeopoldville airlift, to transport UNOC supplies and equipment to and within the Congo. Green also recommended that the Cabinet approve the provision of signals personnel and equipment once immunisation had been completed. George Pearkes reported that a Defence official was in New York discussing the UN's needs with the Secretariat. He anticipated that equipment for UNOC. would cost \$1 million, and was anxious to replace the equipment in Canada immediately. He believed that as many as 500 men would be needed to establish effective supply depots and communications. The Cabinet approved the proposed use of Canadian North Stars in the PisaLeopoldville airlift, and the immunisation of the necessary signal, logistic and administrative personnel of the Canadian Army. Approval for actual participation in UNOC was withheld, but the Cabinet wanted Armed Forces personnel to be prepared in the event that it was granted at a later date. 137

136 Cabinet Documents 236/60 - 238/60: N.A.C., RC:2, Vol. 5937 .

137 Cabinet Conclusions, 21 luly 1960: N.A.C., RCi2, Vol. 2747. 
Within days of the Canadian decision to assign the North Stars to UN duty, a controversy emerged. Tile Cabinet understood that the planes were to be caclusively used to ferry supplies and equipment both to and within the Belgian Congo. Then the Secretary-General approached the Canadian Permanent Mission in New York to request that the North Stars be used for transporting Belgian troops from Leopoldville to Katanga, as part of the troop movements agreed to by Brussels and New York in preparation for the withdrawal of Belgian armed forces. Canada did not want to be seen as acting in concert with its NATO ally in the Congo, and therefore it did not want to be associated with the movement of Belgian forces anywhere in the Congo, especially near the secessionist province of Katanga.

Diefenbaker decided on the 22 July that the planes could not be used for this purpose and notified Howard Green of his decision. Charles Ritchie was then contacted in New York and asked to make this policy clear to the Secretariat. The dilemma was compounded by the discovery that the planes had also been used to transport UN forces to numerous locations within the Congo, so that Belgian paratroopers could be withdrawn. Evidently the Senior RC AF officer in the Congo contacted Air Transport Command Headquarters in Trenton, at the suggestion of Ralph Bunche, and somehow obtained permission to use the RCAF aircraft for deploying Moroccan and Tunisian troops. 138 Ritchie spoke to the Executive Assistant to the Secretary-General, Andrew Cordier, who assured the Canadian Representative that the whole incident had been a 'crash operation'. Nevertheless, Ritchie emphasised that

1.36 Fred Caffen in, In the Eye of the Storm: a History of Canadian Peacekeeping (Toronto: Deneiu \& Wayne Publishers L.td., 1987), suggests that Lieutenant-Colonel J.A. Berthiaume "managed with the connivance of some members of the RCAF to circumvent this restriction and airlift the Tunisian contingent to Kasai province and its capital Luluabourg." p. 2.3.3.2.4. 
the planes could not be used for purposes other than those identified by the Canadian government and insisted that all future requests of a pol: cal nature be forwarded through the Permanent Mission. The Canadian government was determined to participate in UNOC only in a non-combat capacity; the use of the North Stars for prohibited purposes compromised this principle and was thus quickly curtailed.139

On 20 July, the Belgian Ambassador in Ottawa called on External Affairs. There, he met with Deputy Under-Secretary of State for lixternal Affairs Marcel Cadieux. The two discussed various aspects of the situation in the Congo. In particular, the Ambassador was concerned that the Sivviets would attempt a "take-over unless the United States and other friendly countries adopt publicly a firm position." Cadieux acknowledged his concerns and assured him that the Canadian government "was alive to the possibilities of a Soviet coup." He added that it would be helpful for the Ambassador to forward any detailed information concerning communist infiltration in the Congo. Cadieux noted that he had witnessed a communist take-over in French Indochina and realised how upsetting this could be for the former colonial authorities. He stated that he was sure, however, that the Belgian government would take into account the psychological shock that often attended the transfer of authority, as they assessed communist threats. The Ambassador also raised the issues of Katanga's secession and the role of UNOC. He was adamant that the UN should not become involved in the internal affairs of the Congo, and that UNOC. should focu: its deployment in areas where order had not yet been restored. Moreover, he was unequivocally

139 PERMISNY To External 1009: N.A.C., RC:25, Vol. 52(19, File 46346 40 pt. \%: Department of External Affairs Memorandum, 22 July 1960): N.A.C.. RC:25, Vol. 520), lisle \$6386-40 pt. 7. 
against sending UNCX: to Katanga. Cadieux diplomatically suggested that, in his view, such matters were best left to the judgment of the Secretary-General. If the Belgian Ambassador had hoped to find a sympathetic ear, he was must have left lixternal Affairs somewhat disappointed. His government's views were politely acknowledged, but not wholeheartedly accepted. Cadieux first and foremost expressed faith in the UN and Hammarskjöld, and while accepting the possibility that communists might take advantage of anarchy in the (ongo, did not uncritically subscribe to the idea that the Soviets were plotting a take-over. On the one hand, Ottawa had to respect its NATO ally; on the other, it could not ignore the realities of decolonisation and the impact of Belgian interests in the Congo on that country's policies.

That same day, Norman Robertson was visited by Soviet Ambassador Aroutunian. Robertson noted that remarks made by the Ambassador demonstrated the wisdom of the Canadian government's decision not to send combat forces to the Congo. Aroutunian "stated very firmly" his belief that combat troops from NATO countries should not be used in UNOC. He even argued that NATO allies of Belgium should refrain from playing any role in the UN's military operations in the Congo. Robertson took issue with this latter point, and by the end of their conversation had persuaded Aroutunian to "accept the possibility that support units from some NATO countries might have to be incorporated because of circumstances like language problem." The Ambassador also "maintained that if the Congolese (iovernment requested military assistance from the Soviet Union, it would respond, even though he acknowledged that this could create a dangerous situation." $1+11$ Radio reports that day announced Lumumba's intentions to

1.40 Robertson to (ireen, 20 July 1960: N.A.C., RC;25, Vol. 5219, File\#6386-C-40 pt. 1. 
turn to the Soviets for military assistance, should the upcoming se'ssion of the Security Council fail to deliver the complete withdrawal of the Belgian military from Congolese territory. Aroutunian's comments, conibined with these radio reports, must have made the possibility of communist intervention that much more real-except that it would not be so much a 'take-over' as suggested by the Belgian Ambassador, as a 'welcome: ple'asic' come in'. There may not have been a communist plot to infiltrate and influence the Congolese government, but in the early days of the crisis, circumstances certainly existed that would have made communist penetration quite conceivable.

In New York, the Security Council was again in session to consider the Congo situation from 20-22 July. Thomas Kanza, the newly appointed Congolese Minister at the UN, addressed the council and down played the Kasavubu-Lumumba ultimatum of the 17 th. He called on the Council to: and the Belgian aggression, evacuate Belgian forces, refuse recognition of an independent Katanga and facilitate the return of technicians to the ('ongo. The Belgian representative, Secretary of State for Foreign Affairs l'ierre Wigny, argued that Belgium had only intervened for humanitarian reasons and recognised Congo independence as an accomplished fact.141 In the end, a second resolution was passed, which called upon the Belgian government to "speedily" withdraw its forces, as it was already required to do by the first resolution.142 During these meetings, Hammarskjöld raised two issues that would subsequentiy prove to be of great significance. In reference to the first Security Council resolution, he argued that it applied to the entire (ongo as it

141 Catherine Hoskyns, The (ongo Since Independence: January 1960 I) (ecember $|(\%)|$ (london: (Xxford U P, 1965) 150)-152.

142 Security Council resolution 145(196()) is reproduced in Appendix 1. 
existed when it was recommended for admission to the Organization on 7 July. This meant UNOC was entitled to access to all parts of the territory, but it could not be party to any internal conflicts. No one on the Council questioned this interpretation of the resolution. 143

At this session of the Security Council the Soviets again raised the issue of UNOC's composition. They protested the use of American forces, even if only in a logistics or transport role. The U.S. had in fact played a key role in airlifting UNOC personnel and equipment to the Congo. The Soviets did not object to Sweden's role in the peace force, but did reiterate their view that UNOC should be comprised principally of Afro-Asian independent states.144 Hammarskjolld had in fact addressed the issue of force composition in his first report to the Council on the implementation of its initial resolution 143(1960). The report had been released on 18 July and was formally presented to the Council during this session. He asserted the UN's ultimate right to determine the composition of the force, and said that two previously established principles would also be taken into account: (1) permanent members of the Security Council could not contribute units to the force and (2) any nation that might have special interests in the Congo would not be asked to participate. He added that, as much as possible, the UN would take into account the views of the Congolese authorities. He expected African countries to provide a core of combat ready forces. Initially, UNOC consisted of seven battalions from five African countries. Hammarskjöld then approached three European, one Asian and one Latin American country for forces, all of whom he believed met the criteria of 'disinterestedness' set out

143 Catherine Hoskyns, The Congo Since Independence: lanuary 1960-December 1961 (I ondon: Oxford U P, 1965) 151, 155.

144 Rosalyn Higgins, United Nations Peacekeeping, 1946-1967: Documents and Commenlany 4 vols. (O)ford: Oxford U P, 1980) 88. 
as a primary condition on participation. But, as we have seen, by this time UN officials had also approached Canada. It seems that Canada was uniquely suited to filling a void that had not been possible to meet using African forces. Hammarskjold required UNOC support for fields such as logistics, signals, material, aircraft and other specialised personnel that could not be obtained from the 'neutral' nations, that comprised the bulk of the force. The need for bilingual staff made his task even more difficult. For these reasons, the UN pressed Canada for a contribution. Even by December 1960, there were still only six bilingual peacekeepers serving at the Leopoldville headquarters, out of a staff composed of some twenty-nine countries.145

The Congolese Prime Minister, Patrice Lumumba, visited the United States at the end of July. The Americans gave Lumumba and his party a fine reception, although they did not agree to a program of bilateral assistance, the principal goal of the Congolese mission to North America. Instead, the U.S. insisted the Congo receive American aid through the United Nations. While in Washington, he met with Canadian diplomats to make plans for a visit to Ottawa. The events of his official visit to Canada proved to be very frustrating for Canadian officials.

The saga began on 27 July when Lumumba first approached ('anadian officials in the U.S. about visiting Canada and when Mr. Uyttenhove, the Belgian Chargé d'Affaires in Ottawa, visited Howard Green. Uyttenhove was anxious about Canadian opinion on the Congo. He emphatically labelled Lumumba a Communist, who had studied in both Prague and Moscow and was elected to office using money provided by the Eastern Bloc. The Secretary

145 Lincoln P. Bloomfield, "Headquarters-Field Relatinns: Some Notes on the Beginning and End of ONUC," International Organization 17, 16.3): 381; Fdward H. Bowman and James E. Fanning, "The Logistics Problems of a UN Military torce." International. Organization 17 (1963): 361, 372-373; Higgins, 85-87. 
of State for External Affairs stated that there was little he could do about the visit, as it had already been announced in the press. Uyttenhove tried to rally support for Belgium's efforts to retain its military bases in the Congo, and hoped the Canadian government would take a sympathetic view towards the Belgian position in the UN. For his part, Green avoided any commitment, and his comments reflected the government's attempt to remain friendly with both Belgium and the Congo. He concluded by saying that the Canadian Government "would do all they could to avoid making the situation more difficult for the Belgian Government."146 Out of respect for Belgium, Canadian officials did try to limit the fanfare associated with Lumumba's visit. Belgian authorities had been incensed by the reception accorded the Congolese Prime Minister by the Americans. In addition, Lumumba had used the stage afforded by press conferences in the U.S. to 'Belgium bash'-much to the chagrin of career diplomats that looked upon the Prime Minister with scorn for not observing diplomatic niceties.

Canadian officials were not convinced that Lumumba was the avowed Communist Uyttenhove suggested. Rather, he was seen as an inexperienced and untrained leader, eager to grasp at anything that might consolidate 'is political position. In Leopoldville, he had demonstrated a willingness to accept advice from every political vantage. They believed he played East and West against each other, politically and economically. Hammarskjöld had described him as "very responsive to friendship and to frankress, impressionable but apt to be swayed by changing influences ... igriorant, very suspicious, shrewd but immature in his ideas -- the smallest in scope of any of

\footnotetext{
14n Memorandum for the Under-Secretary, 27 July 1960: N.A.C., RG25, Vol. 5225, lile $\$(6.38 \mathrm{~h}-1) \cdot 40 \mathrm{pt} .1$. 
the African leaders." 147

Lumumba arrived in Ottawa on 29 July, accompanied by four other Congolese, two Ghanaians and two Guineans. The latter two groups were African diplomats to the United States that had taken it upon themselves to act as 'guides' for the Congolese. The inclusion of the Guineans, who were considered to be just barely neutral because of the eastward leanings, was a source of embarrassment to Canedian officials. The visit proved to be disappointing. In preliminary conversations, and in his meeting with Diefenbaker, Lumumba was somewhat curt in his replies to questions. Diefenbaker, in an attempt to understand the requirements of a newly independent African nation, asked his counterpart a series of questions that Lumumba refused to answer.

The temperature began to rise, until Diefenbaker frankly asked Lumumba whether or not he expected Canada to pay for french-speaking technical experts the Congolese delegation had hoped to recruit in Canada. By the time Lumumba met with the Prime Minister, he had already learned that Canada would not be willing to engage in any bilateral assistance. He swiftly answered that he "did not expect another Government to pay for the services of Congolese civil servants." This seemed to mark a turning point in his meating with Diefenbaker, because from then on the conversation became "cordial." Diefenbaker offered to assist the Congolese in their attempts to recruit bilingual experts in various fields.

Officials at External were vexed by Lumumba's approach. In his earlier discussions with them, he had expressed the hope that Canada would provide financial assistance and had became somewhat annoyed when he discoverea

147 Memorandum for the Prime Minister, 29 July 1\%60: N.A.C'., RCi25, Vol. 5225, File\#6386-1 - 40 pt. 1. 
that Canada was unable to give such assistance, except through already established UN channels. Evidently, he changed his story for the afternoon meeting with Diefenbaker and blamed Canadian officials for an; misunderstariding that may have led to the perception that he was hoping to have Canada pay a share of the planned technical assistance program. This left a very bad taste in the mouths of Ottawa diplomats. Following his departure, Robertson summed him up as "vain, petty, boorish, suspic!ous and perhaps unscrupulous." 148

There was also the curious matter of a "secret" visit he had with the Soviet Ambassador to Canada, Aroutunian. Robertson later wrote tha: Lumumba greeted Aroutunian in a "very friendly and warm fashion"when he first arrived at the Ottawa airport. There was also at least one man from the Soviet Embassy "constantly on duty" at the Chateau Laurier, where the Congolese party was staying. While speaking with Bernard Salumu, Lumumba's Private Secretary, one Canadian official was interrupted by someone from the Soviet Embassy who only reluctantly revealed his identity after asking for Salumu's room number in French, with a slavic accent. At the time, few details were known about the meeting between Aroutunian and Lumumba. An RCMP guard rsported seeing the Soviet Ambassador with the Congolese Prime Minister on Saturday morning, and that during the visit a phone call had been placed to Washington. Later, it was ciscovered that Aroutunian promised Lumumba a gift of transport vehicles. 149

The cloak and dagger activities in the lobby of the Chateau Laurier and the rather blunt Canadian assessments of Lumumba and his entourage make

\footnotetext{
148 Robertson to Green, 1 August 1960: N.A.C., RG25, Vol. 5225, File\#6386-D-40 pt. 1.

149 Rohertson to Green, 1 August 1960: N.A.C., RG25, Vol. 5225, File \#6386-D-40 pt. 1 and Memorandum from Information Division to Commonwealth Division, 2 August 1960: N.A.C., RC.25, Vol. 5225, File $\sharp 6.386-1)-40 \mathrm{pt} .1$.
} 
for interesting reading. 150 Nonetheless, the visit was a significant event for Lumumba because his experiences in North America coloured his later actions and decisions. Diefenbaker has said that Lumumba's call on Ottawa did little to help his understanding of the Congo situation.151 By contrast, it was a formative experience for the Congolese leader. His mood changed during the visit, and his opinion of the UN was diminished. Both American and Canadian officials had couched their decision not to give any bilateral assistance by reiterating commitments to provide aid through the UN. Lumumba thus came to think of the UN as an "obstacle to quick action and to the kinds of aid he sought."152 I'e realised that he was not going to get the help he desired from either the U.S. or Canada and so turned to the Soviets, even before he had eft Ottawa. In subsequent months reports of L:Imumba's view of Canada filtered in to External. He thought that he had been rebuffed by Ottawa. In October, at a dinner to celebrate the ind anniversary of Guinea's independence, Lumumba delivered a speech in which he said that he had gone to Canada "to seek bilateral aid in belief that it was a truly democratic land but had been disappointed to find that although honest Canada was just another imperialist country." 153 Diefenbaker later added another reason for Lumumba's poor opinion of Canada: "the failure of Howard "reen and the

150 These blunt assessments were not reserved for Lumumba alone. A Congolesc Ordnance Officer by the name of Captain Mawoso accompanied Lumumba on his visit to Ottawa. Cadieux described him as "a sincere, but somewhat inarticulate and limited individual. He spoke without resentment, but I have the impression that he would describe in the same smiling fashion a fire that destroyed his house or a flood that had clizinated a number of villages." Memorandum for the Under Secretary, 30 july 1960: N.A.C., RC:25, Vol. 5225, File $\$ 6386-\mathrm{D}-40$ pt. 1.

15' ihn G. Diefenbaker, One Canada, 3 vols. (Toronto: Macmillan of Canada, 1975. $1976,1977) 2: 128$.

1,2 Rosaly n Higgins, United Nations Peacekeeping, 1946-1967: Documents and Commentary, 4 vols. (Oxford: Oxford U P, 1980) 127.

153 PERMISNY to USSEA, 3 December 1960: N.A.C., RG25, Vol. 5225, File\#6386-1 )-40, pt. 1 and Leopoldville to External, 3 October 1960: N.A.C.., RG25, Vol. 5225, File \#63866-1)-40, pt. 1. 
ofticials at the Department of External Affairs to provide him with female companions during his visit." 154

The day before Lumumba arrived in Ottawa, the Canadian Cabinet decided to provide the logistics and signals personnel the UN had requested. From discussions with the Secretariat, the precise needs of UNOC emerged. The Minister of Defence noted that the crisis was moving swiftly and changing constantly; this made it difficult to determine UNOC requirements. He recommended that Canada provide: a signals detachment for UNOC. headquarters, including signal office, message centre, a 100-line switch-board, linemen and dispatch riders; five ground to air communication links, and possibly two more at a later date; twelve mobile wirele's detachments; eight cypher detachments and four composite logistic depots. That same day, External Affairs contacted the Permanent Mission in New York to request that they inform the Secretariat of Canada's willingness to provide signallers and a small Canadian headquarters detachment. This was to be kept in confidence until after Parliament had been notified.

In support of Canadian participation, Howard Green argued that “Much had been made of Canada's support of the United Nations. Not to do what the Minister of National Defence had suggested would be a mistake."155 Thus, the importance of public opinion and Canada's self-image did enter into the decision. However, evidence suggests that other considerations were also taken into account. At the time when the government made its decision, the situation in the Congo had improved somewhat. General Alexander, the British Commander of the Ghanian forces in the Congo, "foresaw no danger

154 John C. Diefenbaker, One Canada 3 vols. (Toronto: Macmillan of Canada, 1975, 1976, 1977) 2:128.

1.55 Cabinet Conclusions, 28 Julv 1960: N.A.C., RG2, Vol. 2747. 
to white personnel serving the United Nations, so that non-combatant Canadian support troops need to be supplied with personal weapons only." $15 n$ In a memorandum to Cabinet, Pearkes and Green further argued that initial political objections to the addition of white personnel to the Force, even if these forces were drawn from NATO countries, were no longer valid because UNOC contained both African and non-African combat contingents. The fact that Canadian peacekeepers would provide technical support and avoid a combat role, unlike some of their non-African and most of their African counterparts, certainly made the proposition much more palatable. The government was consistently concerned to limit the risk to Canadian lives. Because some peacekeepers were bilingual, the Cabinet also recognised that they were uniquely suited to UN service in the Congo. Moreover, concern for the success of UNOC, and indeed the United Nations itself, was expressed by Norman Robertson:

The significance of the United Nations role in the Congo cannot be fully measured at this time but there is no doubt that it has far-reaching implications for the Congo, for Africa and for the United Nations itself. Success in tne Congo may lay the groundwork for many other operations of the United Nations in Africa, especially as regards the peaceful parts of the programme. Success for the United Nations in the Congo and in Africa might establish the Organization firmly as the strongest influence for peace in the world. Undoubtedly, success in the Congo will raily public support but with that public support must come the material support, as distinct from lip service from member states. Failure, on the other hand, in the Congo might mean the final failure of the United Nations. 157

The success of the United Nations in Africa, also meant the failure of communist penetration. The Cold War implications of the crisis were taken into consideration. Slearly, Cabinet support for UNOC was provided, not

15 h Cabinet Document 243/60: N.A.C., RC:2, Vol. 5937.
157 Roberison to Green, 27 July 1960: N.A.C., R(;25, Vol. 5209, 6386-41) pt. 8. 
simply from a single-minded fear of public reaction to a limited Canadian response, but for a number of different reasons. On August 1st, the government's tecision to send forces to the Congo was debated in the House of Commons and received support from all parties. An order in council was subsequently approved by the Cabinet on 5 August, giving "authority for the maintenance on active service of up to 500 officers and men of the Canadian Armed Forces as part of or in support of the United Nations operations in the ('ongo."158

158 (nbinet conclusions, August 5 1960: N.A.C., RG2, Vol. 2747. 


\section{Chapter 3 \\ Operation Mallard: \\ The Early Canadian Contribution to UNOC}

Within hours of the Security Council's decision to create UNOX , the first contingents arrived in the Congo. The acting Canadian Trade Commissioner, Roger Bull, was disappointed in the United ' 'ations' initial response to the crisis. He found Ralph Bunche to be a "quiet self-effacing man" that didn't want to "expose himself to criticism" by doing t(x) much before it was clear that the UN was willing to assume a role in resolving the crisis.159 On 14 July, Major-General Alexander, a British officer serving with the Ghanaian army, arrived on the scene. Bull suggested that this "immediately stiffened the U.N.'s backbone."160 Because von Horn was unable to get to the Congo until $18 \mathrm{July,} \mathrm{Alexander} \mathrm{assumed} \mathrm{a} \mathrm{prominent} \mathrm{role}$ in directing the early activities of UN peacekeepers. It was during this initial period of deployment that Alexander ordered peacekeepers to disarm the Force Publique. This may have seemed a reasonable course of action to him at the time, but it was clearly outside of UNOC's mandate and so Bunche disagreed with his decision. Much to Lumumba's dismay, however, the Ghanaian troops did start to disarm the Force. While these attempts met with initial success, disarmed Congolese troops took up arms once again by 23 july. The whole affair did much to colour Lumumba's early perceptions of UNOC. 161

159 Bull to USSEA, 5 August 1960: N.A.C.., RC25, Vol. 5209, File $\$ 6.386 .40$ pt. 9.

160 Bull to USSEA, 5 August 1960: N.A.C., RC25, Vol. 52199, File\#6.386-40 pt. 9.

161 Alexander's attempts to disarm the Force Publigue are outlined in grealer detall in Catherine Hoskyns, The Congo Since Independence: January 196()-1)ecember $1 \%$ ! (I ondon: Oxford U P, 1965) 133-139. 
The arrival of vo.. Horn and his "triumvirate of Canadian staff officers" infused the UN with an "an air of decision and activity." 162 The sheer size of the Congo operation meant that the initial chaos and confusion inherent in any multinational military operation was multiplied. Within days, five to six thousand peacekeepers were deployed over a vast area, without adequate transportation. Some had only four days of hard rations. In addition, von Horn had insufficient notice of when reinforcements were expected to arrive. He knew little about the equipment they intended to bring, or how their units were organized. The Irish, for example, arrived in winter uniforms.163 The inability to efficiently and securely communicate between UNOC detachments made their tasks particularly formidable. For the first four weeks, until Canadian Signals personnel arrived, they relied on a hotel switchboard, commercial telegrams, amateur 'ham' radios and Air Congo teletype circuits. For security purposes, the force used native languages "Amharic to the Ethiopian brigade, Arabic to the Tunisians, Gaelic to the Irish, and Swedish to the Swedes." 164

The European exodus continued, but by 18 July Roger Bull believed conditions were sufficiently safe to recall the families and office staff who were evacuated to Brazzaville in the early days of the crisis. The appearance of UN peacekeepers in Leopoldville provided an initial sense of safety and comfort. Bull wrote,

We have Swedes practically next door to us in the office building, Ghanaians across the street from the Residence and blue armbands lurking behind every bush to protect us. Miss Morel, in fact, has found the excitement so invigorating that her

162 Hull to USSEA, 5 August 1960: N.A.C., RG25, Vol. 5209, File $46386-40$ pt. 9. 16.3 Lincoln P. Bloomfield, "Headquarters-Field Kelations: Some Notes on the Beginning and find of (ONUC," International Organization 17 (1963): 379.

Ind lincoln 1. Bloomfield, "Headquarters-Field Relations: Some Notes on the Begrnning and lind of ONUC:" International Organization 17 (1963): 384. 
health is almost restored to normal.165

Regular office work, much like the rest of I ceopoldville, came to a standstill. The staff was nonetheless kept busy. The first of the Canadian North Stars arrived in Leopoldville with their cargo of food aid on 21 July. The Trade Commission staff fed and housed the twenty-four crew members and subsequently arranged for them to stay in the guest house of a local company. By 24 July, another thirty-nine RCAF personnel had arrived and the seven available beds in the official residence, as well as the entire guest house, were filled.

Once Cabinet had approved the dispatch of the Signals unit, the army lost no time in sending an advance party to the Congo to inspect conditions. Colonel Albert Mendelsohn, an officer with a military enginecring background and experience in the United Nations Military Observer Croup in India and Pakistan, led the group. His initial reports in the first week of August were favourable. He found that Leopoldville was gradually returning to normal. Some of the basic utilities had been restored and the "white area" of the city appeared to be quite modern, with buildings "equal to the best in Ottawa." He noted that UNOC. headquarters personnel did not carry personal weapons and were able to move about freely without any trouble. The local Tongolese seemed "quite unconcerned and happy." Ile acknowledged that his observations were based principally upon I.eopoldville, but expected other major cities, where Canadian personnel might be deployed, to be comparable with respect to accommodation and utilities. 1 hh

The formation of two units of the Canadian Army to support UN( $x$

165 Bull to Hughes, 1 August 1960: N.A.C., RC;25, Vol. 52(99, File $\# 6386-40$ pt. 9.

l hh Mendelsohn to AHQ, 2 August 1960: N.A.C., RC:25, Vol. 5219, File H6336 (' 4") pt. 3 and Mendelsohn to AHQ, 4 August 1960: N.A.C., RC:25, Vol. 5219, Iile\#636h-( $40 \mathrm{pt} .3$. 
was authorised effective 27 July 1960.167 Military personnel of the new Canadian Headquarters, United Nations Force in the Congo and Number 57 Canadian Signal Squadron assembled in Barriefield, Ontario. There, the future peacekeepers were processed and inoculated for tropical service. Beginning on 9 August, and in regular intervals throughout the month, groups of Signallers travelled to Trenton, where they departed for the Congo. Canadian Headquarters, UNOC arrived in Leopoldville on 15 August.168 Ultimately, the Canadian contingent was on average 280 strong. The heart of the unit remained at UNOC headquarters in Leopoldville, but a number of small detachments were sent to locations in the interior, including: Elizabethville, Coquilhatville, Luluabourg, Kamina, Stanleyville, Gemena, Matadi, Goma, Kindu, Albertville, Kongolo and Bukavu.169

In the initial weeks following UNOC's deployment, Bull reported on three political demonstrations in Leopoldville which were relatively orderly. In fact, he noted that a Canadian reporter who got too close to one of the demonstrations had his foot stepped on and received an immediate apology. Prime Minister Patric: Lumumba was not so lucky. When he appeared at one of the dem .strations, he was stoned and his car was smashed by a hostile crowd. 170)

In these early days, however, there were incidents that foreshadowed the serious difficulties Canadian peacekeepers would also ultimately encounter. (On 15 August, a crowd of two hundred Congolese surrounded a jeep containing two (anadian members of UNOC. Because they were

167 Allard, 2 August 1960: D.Hist, 410.CONGO (D1).

I68 War Diary, CDN HQ UNOC, August 1960: N.A.C., RG24, Vol. 18,482, Folder 9. 1 th Fred Gaffen, In the Eye of the Storm: a history of Canadian peacekeeping (Toronto: Demeau and Wayne Publishers Lid., 1987) 227.

170 Bull to USSF, 19 August 1960: N.A.C., RG25, Vol. 5209, File $\$ 6386-40$ pl. 10. 
speaking fluent French, the crowd believed they were Belgians. One of the peacekeepers tried to calm the crowd, but as this was accomplished on one side of the jeep, people on the other side were rallied by three or four agitators. Fortunately, a Congolese police patrol arrived on the scene, confirmed the identity of the peacekeepers and dispersed the crowd.171 Earlier, Lumumba had announced on the radio that Belgians were masquerading in UN uniform and this started a "witch hunt" for Belgian "spys and saboteurs." The four unsuspecting peacekeepers were almost victims of a vigilante mob out to find these disguised Belgians. Lumumba was anxious tr prove that he was still in charge, and that the (ongo had not become a UN colony. Such incidents demonstrated his ability to exercise a degree of control and aucnonty. 172

By contrast, Dr. Phil Edwards, a black Canadian doctor serving with one of two Canadian Red Cross medical teams, was received very well by the Congolese. Roger Bull reported that Edwards made "a most favourable impression here." 173 These two teams stayed temporarily with Bull until they flew on to Coquilhatville to reopen the hospital and Institute of Tropical Medicine. Once the majority of Europeans had fled the Congo, medical personnel were in short supply. This is one example of how ('anada contributed to UN sponsored or initiated technical assistance programs, in addition to the provision of peacekeepers for UNOC.. The Canadian Red Cross recruited the personnel for these medical teams, and the Cabinet agreed to fund the mission with $\$ 44,900$ from the International Relief liund. 174

On 2 August, the Canadian government received a request for

171 War Diary, CDN HQ UNOC, August 1960: N.A.C., RG24, Vol. 18,4k2, Folder 9.

172 Wood to USSEA, 18 August 1960: N.A.C., RC,25, Vol. 5219, file $\$ 6336$-( '-40 pt. 3.

173 Bull to USSEA, 5 August 1960: N.A.C., RC;25, Vol. 5209, Iile \#6 386 411 p1. 9.

174 Cabinet Conclusions, 4-5 August 1960): N.A.C., RC;2, Vol. 2747. 
technical assistance of a different kind. Ghana intended to establish a bilateral training program with the Congo that would see Congolese cadets trained as force Publique officers at the Ghana Military Academy. The Ghanaian l'resident, Dr. Nkrumah, hoped that Canada would cooperate in this venture by providing approximately twenty French-speaking members of the Armed Forces to assist in the training. External Affairs considered the request with caution. Officials questioned the Ghanaian motives for the proposal; Ghana and Guinea had recently made known their interest in establishing a federation with the Congo. All in all, officials at External preferred to coordinate Congolese assistance through the UN. They suggested that Britain, the U.S. and the UN all be consulted to ascertain their views on such a proposal.175 The Minister of National Defence, George Pearkes, was even more reluctant. He wrote to Diefenbaker to encourage him to reply negatively to the request on the grounds that there was a shortage of highly trained French-speaking personnel, adding that a UN sponsored initiative would be preferable to a bilateral agreement.176 The Cabinet considered the request on 12 August, and their deliberations were greatly simplified when I lammarskjöld cabled Canadian authorities to request a similar training program under UN auspices. The timely arrival of a UN request provided the government with a diplomatic reason to reject participation in Ghana's training scheme.177 On 26 August, the government officially declined involvement in Nkrumah's plans; he was told that Canadian participation in efforts to "re-establish order in the Congo" were being carried out "through

175 Robertson to Grenn, 4 August 1960: N.A.C., RG25, Vol. 5219, File\#6386-C-40 pt. 2. 17n Pearkes to Diefen saker, 9 August 1960: N.A.C., RG25, Vol. 5219, File\#6386-C-40 p1. 2.

177 Cabinet Conclusions, 12 August 1960: N.A.C., RC2, Vol. 2747. 
the United Nations." 178 By this time, however, even the UN plan had been shelved by Cabinet. The first Canadian casualties in UNCX' had given the government good reason to be cautious about committing any more personnel to UN activities in the Congo.174

By the end of August, UNOC had achieved the withdrawal of Belgian forces from all of the Congo, except Katanga and the Belgian military basies at Kitona and Kamina. Katanga's declaration of independence on 11 July complicated matters considerably. Hammarskjöld faced pressure fron. Lumumba, who wanted to use UNOC forces "to help his Ciovernment put down the secession of Katanga by force." 180 The Secretary-Cieneral disagreed with Lumumba's interpretation of Security Council resolutions $143(1960)$ and 145(1960). He argued that these prevented UNOC. from using force, except in self defence, and that they also clearly prohibited intervention in any internal Congolese conflict.

Hammarskjöld also disagreed with the Katangese and Belgian authorities' views on the implementation of the UN resolutions. Belgium gave essential support to Moìse Tshombe's separatist regime, "contrary to the intention of the July and August 1960 resolutions."181 Financially, the Belgian mining conglomerate, Union Minière du Haut Katanga, provided $80 \%$ of the régime's revenue.182 Thus, it is not surprising to learn that the Belgians perceived no need for the UN to enter Katanga. They argued that the Belgian

178 Robertson to Diefenbaker, 24 August 1960: N.A.C'., RC ;25, Vol. 5219, Iille \$6, 166 ( ' 411 pt. 3.

179 Cabinel Conclusions, 17 August 1960: N.A.C., RCi25, Vol. 2747.

180 United Nations, Department of Public Information, The Blue I lelmets: A Review of United Nations Peace-keeping, 2nd ed. (New York: United Nations, 199()) 224.

181 Wynfred Joshua, "Belgium's Role in the UN Peacekeeping ( Pperation in the ('ongo," Orbis 11.2 (1967): 437.

182 David Gibbs, "Dag Hammarskjöld, the United Nations, and the ( ungo" ( risl", of 1960-1: a Reinterpretation," The Journal of Modern African Studiess 31.1 (1963): 16,5166 
military, together with forces loyal to the secessionist government, had already restored law and order. The Secretary-General, however, believed that the mandate of UNOC required the force to be deployed throughout the ('ongo, including Katanga. With this in mind, Hammarskjöld sent Bunche to Katanga on 4 August to negotiate the entry of UN forces. When it became clear to the UN envoy that this was not going to be possible "without bloodshed," Hammarskjolld decided to consult with the Security Council before pressing forward. 183

On 9 August, the Council passed resoiution 146(1960).184 It confirmed the authority vested by the Council in the Secretary-General and called upon Belgium to immediately withdraw its forces from Katanga. It also asserted the necessity of UNOC's entry into the break-away province, but required that UNOC not become a party to, or influence the outcome of, any internal conflict. In effect, the UN force was obliged to prevent civil war in the Congo and this meant that Hammarskjöld could not condone the Lumumba government's "forcible occupation of Katanga" any more than "Katanga's forcible secession." 185 Once the Security Council had eridorsed his actions, the Secretary-General was in a much stronger position. He returned to Katanga in order to negotiate the peaceful entry of UN forces.

Along the way, Hammarskjöld wrote a memorandum that outlined his interpretation of UNOC's role. It emphasised the UN force's obligation not to intervene in the conflict. This memorandum, along with Hammarskjöld's decision to fly directly to Elizabethville for negotiations with

183 United Nations, Department of Public Information, The Blue Helmets: A Review of United Nations Peace-keeping, 2nd ed. (New York: United Nations, 1990) 225.

184 Security Council resolution 146(1960) is reproduced in Appendix 1.

I 85 Nicholas Herbert, "UN Peace Forces and the Changing Globe: the Lessons of Suez and (ongo," International Organization 17 (1963): 331 -332. 
Tshombe, infuriated Lumumba. He wanted the Secretary-General to consult the central government before taking any action to resolve the Katanga issue, and expected to accompany him on the trip to Flizabethville. Hammarskjobld's decision to take along Swedish peacekeepers, as the first of the UNCX forces: to be deployed in Katanga, further annoyed Lurrumba. The C'ongolese Prime Minister suspected that Hammarskjold was conspiring with the lielgians, and perceived the Secretary-General's decision to be accompanied by Swedes as proof of such a conspiracy. $18 \mathrm{n}$

These differences of opinion over UNOC's role in Katanga resulted in a marked shift in Lumumba's views.187 He became increasingly hostile to Hammarskjöld, the West and white UN forces. His press attaché, Serge Michel, recounted Lumumba's belief that "all Westerners in the ('ongo were' racists.' He said of white UN forces:

'They're afraid. How can you imagine that, just like that, a hat painted blue is enough to eliminate the complexes of conservative officers from Sweden or Canada or Great Britain?' Their vision of Africa ... was one of lion hunts, slave markets, and coisn:ol conquests, and they sympathized with the Belgians: because they had 'the same past, the same history, the same taste for our riches.' 188

From this point on, Lumumba began to call for the withdrawal of white peacekeepers. Hammarskjöld strenuously rejected thesc demands, on the grounds that the UN alone had the authority to determine the composition, of its peacekeeping forces.

UNOC's racial composition had been an issue right from the force's

186 Brian Urquhart, Hammarskjold (New York: Alfred A. Knopf, 1972) 429.430.

187 Stephen R. Weissman, American Foreign Policy in the Congo, 1960)-1964 (Ithaca: Cornell U P, 1974) 64-84; Madeleine G. Kalb, The Congo Cables: The Cold V'ar in Africa Irum Eisenhower to Kennedy (New York: MacMillan Publishing Co, Inc., 1982) 4: 50; (3rian Urquhart, Hammarskjold (New York: Alfred A. Knopf, 1972) 429-430.

188 /as quoted in/ Madeleine G. Kalb, The Congo Cables: The Cold War in Alruca Irom Eisenhower to Kennedy (New York: MacMillan Publishing Co, Ir.c., 1982) 4950. 

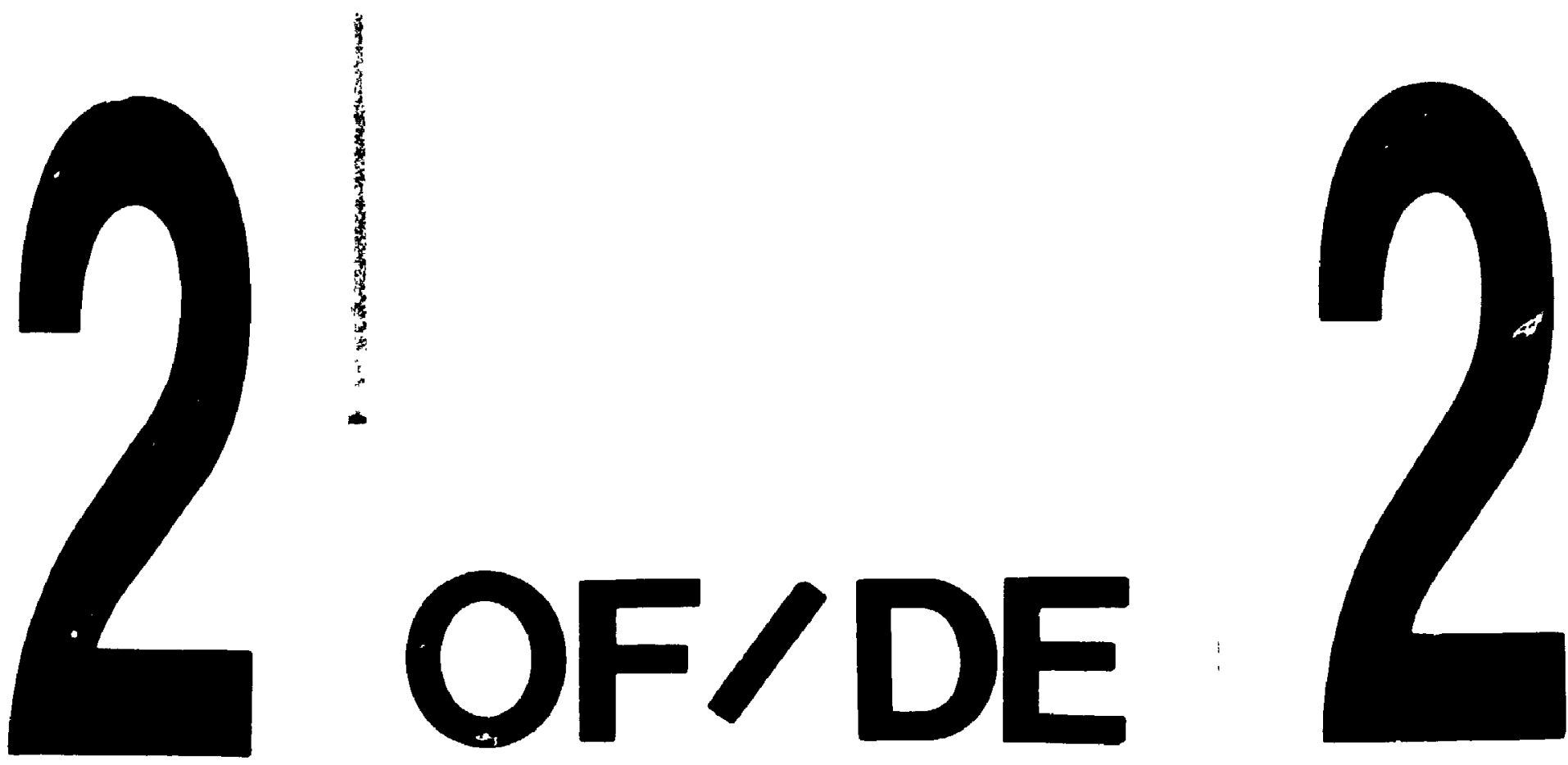

PM-1 31\%" $\times 4 "$ PHOTOGRAPHIC MICROCOPY TARGET NBS 1010. ANSI/ISO "2 EQUIVALENT

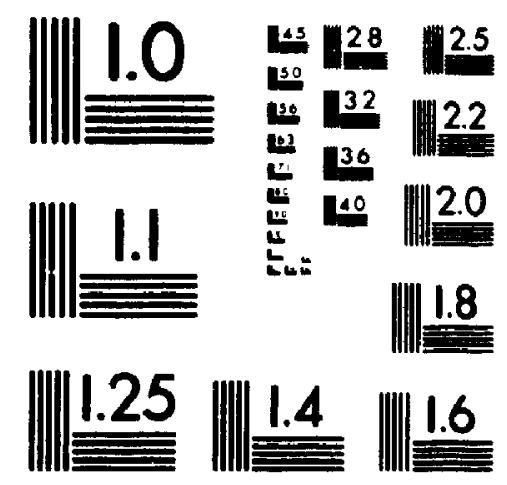

PRECISIONSM RESOLUTION TARGETS 
early days. The Soviets attempted to limit participation to African and Asian nations when the force was established. Although their effort failed, Hammarskjöld nonetheless deliberately called on these nations to provide the majority of combat forces for the first stage of UNOC. Prime Minister Diefenbaker, it will be recalled, was against the idea of sending white Canadians to the Congo, especially those who were French speaking, if the UN expected to use them in a combat capacity. Diefenbaker feared the possibility that Canadians might be mistaken for Belgians, and given the enmity between the Congolese and their former colonial caretakers, the potential for physical harm was far too great.

Although the Canadian peacekeepers did not serve in a combat role in the Congo, they still regularly came into contact with both the Congolese and Lumumba's Armée Nationale Congolaise (ANC). The events of 18 August, when the first incident of serious violence between Congolese and Canadians happened at the N'diili airport, Leopoldville, demonstrated that Diefenbaker's concerns were not unwarranted. Two groups of Canadian peacekeepers were waiting to depart on reconnaissance missions to Coquilhatville and Luluabourg. Those destined for Luluabourg were delayed on the tarmac. A patrol of about ten to twelve Congolese soldiers suddenly rushed towards them. The peacekeepers presented their UN identity cards and tried to identify themselves as Canadian. The Congolese were unimpressed, forcing them face down onto the tarmac, arms extended. They then kicked the peacekeepers, focusing their efforts particularly on the commanding officer, Captain J.C.A.A. Taschereau. The peacekeepers destined for Coquilhatville, along with the Indian air crew and some Moroccan passengers, were removed from their aircraft and together with the first 
group of Canadians, were herded into an awaiting truck. Their wallets and valuables were stolen, and blue UN berets removed. At this point, Taschereau was hit in the face with the butt of a rifle and knocked unconscious. Another Canadian was struck in the back with such force that the rifle butt broke. Others suffered cuts and bruises. Luckily, after about 12 minutes, a Danish officer accompanied by Ghanaian troops rescued the Canadians. 189

Hammarskjöld, once informed of the incident, promptly drafted a letter to the Congolese Ambassador to the U.N. He stressed the "extreme gravity" of the incident, drawing attention to the unacceptable conditions faced by peacekeepers in UNOC. The Secretary-General threatened the Lumumba government with the withdrawal of UN support and assistance with a warning that "further activities may be rendered impossible" if the peacekeepers' working conditions did not improve.190 This letter was followed by an official note of protest to the Congolese government. In this note, he repeated his threat by suggesting that all UN activities in the Congo might have to be submitted to the Security Council for reconsideration. Hammarskjöld made it clear that he expected the government to immedintely take "all measures necessary to forestall the recurrence of any such incidents." 191

Diefenbaker summoned Norman Robertson to his office and set to work drafting a Canadian letter of protest. Parliament had been prorogued for

189 Wood to USSEA, 20 August 1960: N.A.C., RG25, Vol. 5219, File $\sharp 6386-C-40$ pt. 3; Fred Gaffen, In the Eye of the Storm: a History of Canadian Peacekeeping (Toronto: Deneau \& Wayne Publishers Ltd., 1987) 224-225; "UN Troops at Airport Get Orders to Shoot," Globe and Mail (Torontol 19 August 1960: 1.

190 Hammarskjöld to Congolese Ambassador to the U.N., 18 August 1960: N.A.C., RG25, Vol. 5219, File \#6386-C-40, pt. 3.

191 PERMISNY to External, 19 August 1360: N.A.C., RG25, Vol. 5209, File \#6386-40 pt. 10. 
the summer and so reaction from the Opposition is not known. Diefenbaker, however, was "obviously annoyed."192 In a note "as strong as any employed by a Canadian head of government to a foreign leader," he stated:

Such totally unwarranted and unjustified attacks on Canadian Service personnel are of a most serious character. I expect an immediate assurance that effective measures will be taken to ensure that the forces under your control will refrain from threatening the security of Canadian personnel who proceed to your country on friendly and peaceful missions in the performance of tasks determined by the United Nations. 193

Reporters were called to the Prime Minister's office and shown the contents of the letter sent to Lumumba. With "rumpled" hair and in a harsh tone, Diefenbaker warned that the Canadian Government took a "serious view of the totally unwarranted and unjustifiable conduct of the Congolese soldiers." 194 He had considered the implications of possible Canadian casualties weeks before Cabinet finally decided to participate in Uivor. Once injuries actually occurred, he appeared determined to deal with them forcefully and quickly. Doubtless he anticipated that Canadians would be indignant over the treatment of their peacekeepers, and he cannot have expected the editorial that appeared in the Globe and Mail the following day. It seriously questioned the wisdom of Diefenbaker's letter of protest, arguing that only the UN should dispatch such grievances, given that it had assumed jurisdiction in the Congo crisis. The editorial concluded by exhorting the Canadian Government to display the same "conspicuous se:i-control and patience in the face of all provocations and dangers," that was displayed by the

192 "Diefenbaker Alters View on Gravity of Incidents," Globe and Mail|Torontol 19 August 1960: 1 .

193 "Diefenbaker Alters View on Ciravity of Incidents," Globe and Mail (Torontol 19 August 1960: 1; Robertson to Diefenbaker, 18 August 1960: N.A.C., RG25, Vol. 5209, File \#6386-40 pt. 10. August 1960: 1 .

194 "Diefenbaker Alters View on Gravity of Incidents," Globe and Mail|Torontol 19 
UN personnel involved in the incident. 195

The principal UN officials paid tribute to the conduct of the Canadian peacekeepers. Brigadier Rikhye, who was then serving as Military Advisor to Hammarskjöld, contacted Norman Robertson and said that Taschereau and his men "behaved admirably throughout the incident under the most severe provocation." They would have been justified in using their arms in selfdefence, instear" they demonstrated "extreme restraint" in their attempts to reason with their attackers.196 The Supreme Commander of UNOC, von Horn, sent a message to the Canadian Chief of General Staff, S.F. Clark, expressing his "admiration for the very high standard of discipline and for the courage and forbearance shown by your troops." He added, "I thank them, congratulate them on their splendid conduct in the face of needless and senseless provocation and I am proud and honoured at having them under my command."197 In his memoirs, von Horn recalled that the N'djili incident had a "profound impact on everyone" in UNOC. From this point on, very few members of $t_{t}$ ' force disguised "their hostility towards the Congolese." He remembered strapping on his own pistol before heading to the airport to see the remaining Canadians flown in.198

On 19 August, Lumumba held a press conference in Leopoldville to address Hammarskjöld's note of protest. The Congolese Prime Minister considered the $N^{\prime}$ djili incident "commonplace," and suggested it had been blown out of proportion by the Secretary-General as a diplomatic manueuvre. He made reference to an identity control system recently implemented by the

\footnotetext{
195 "A Time for Coolness," Globe and Mail [Torontol 19 August 1960:6. 196 Robertson to Clark, 24 August 1960: N.A.C., RG25, Vol. 5219, File \#6386-C-40 pt. 3. 197 Robertson to Diefenbaker, 22 August 1960: N.A.C., RG25, Vol. 5219, File \#6386-C-40 pt. 3.

198 Major-General Carl von Horn, Soldiering for Peace (London: Cassell, 1966) 188-189. $-93-$
} 
government as a means to discover the "many persons of foreign nationality" who were infiltrating the Congo. He maintained that the Congolese soldiers at N'djili airport on 18 August were simply trying to verify the identity of the Canadian soldiers, who had in turn "categorically refused to show their papers and behaved rudely." To counter Hammarskjöld's charges, he argued that the Congolese army was subjected daily to "uncalled-for affronts and humiliation by the UN European troops." He concluded his press conference with a demand for the withdrawal of the white UN troops who had "provoked the latest incidents." 199 Howard Green declined to comment on Lumumba's allegations against the Canadian peacekeepers before the Security Council could meet to consider the situation, but a UN spokesman "curtly" denied the charges, asserting that identification badges were shown and that the peacekeepers had not "behaved badly."200

Lumumba's version of events was seriously undermined by the Chief of Staff of the Congolese National Army. At almost the same time as the Prime Minister was holding his press conference, Colonel Mobutu delivered an official apology to Ralph Bunche. It stated, "We are extremely sorry that precise instructions had not been given in time to the company on duty at the airport, as that might have prevented the shameful occurrence at Ndjili." Bunche was assured that strong measures had been taken against the soldiers responsible for the incident.201 In the days that followed, Lumumba himself somewhat softened his stand by apologising for the "minor" $\mathrm{N}$ 'djili incident and for his soldiers' excessive zeal in carrying out their orders to check all

199 PERMISNY to External, 21 August 1960: N.A.C., RG25, Vol. 5219, File $\$ 6386-C-40$ pt. 3. 200 "UN Denies Charges Against Its Troops," Globe and Mail [Toronto| 20 August 1960: 1. pt. 10.

201 PERMISNY to External, 21 August 1960: N.A.C., RG25, Vol. 5209, File $\$ 6386-40$ 
identification. He ordered the army to act "with tact and dignity in future."202

Within two weeks, however, there was another serious and violent incident between Congolese forces and Canadian peacekeepers. Six members of the Signals Squadron left Trenton on 27 August aboard two United States Air Force Globemaster aircraft. The U.S. had agreed to transport heavy equipment required by the Signallers, that could not otherwise be transported by RCAF planes. The Canadian officer in charge, Capt. J.J.B.L. Marois, was accompanied by three other peacekeepers in the first plane. He assigned two others, Cpl. Gavel and Signaller Bone, to accompany the remainder of the squadron's equipment in the second plane. One hour and fifteen minutes after the first plane left, the second also departed. Marois and his group left first, so that they would be able to organise equipment and arrange to meet the second plane when it landed.

The first plane reached Stanleyville at 8:30 am. The four Canadians noticed what looked like three companies of the Congolese army, as well as a company of Ethiopian peacekeepers on the tarmac. They disembarked, unloaded the aircraft and assisted in the departure of the airplane. A UN officer then escorted them to the UN headquarters at the Hotel Wagenia. Moments later, Congolese soldiers looking for Belgian paratroops rushed into the Stanleyville Headquarters and demanded to see the four recently arrived Canadians, so that their identification could be established. They were loaded into jeeps at gun point, along with three UN civilians and three other Canadian peacekeepers, including Captain J.J.B. Pariseau, who had already been detained the previous week for the same purpose. The Congolese commander assured Pariseau that no one would be killed, and explained that

202 "Lumumba Apologizes to Canada," Globe and Mail |Toronto| 22 August 1960: 1. -95 - 
the whole affair was only for "political appeasement." Nevertheless, they were beaten, searched, stripped and placed in cells where they were kept for forty-five minutes until an Ethiopian Brigade Commander arrived to rescue them.

In the meantime, Cpl. Gavel and Signaller Bone arrived in the second American plane. A crowd formed on the airfield and was stirred into a frenzy by reports that the plane contained Belgian paratroopers. Patrice Lumumba was expected to arrive shortly in another airplane and rumours quickly spread that the 'paratroopers' had been sent to assassinate the Congolese leader. Gavis!, Bone and the American air crew were pulled from the plane and severely beaten by Congolese soldiers. The two Canadians were flown to Leopoldvilie to be hospitalised for a week. General von Horn deployed three hundred peacekeepers around the plane bearing the wounded soldiers when it landed at $N^{\prime}$ djili airport and threatened to fire the first shot if there was any interference. 203

Canadian reaction to the Stanleyville attack was swift. The Acting Consul General in Leopo'dville, Mackenzie Wood, made a verbal protest to Congolese Foreign Minister Bomboko. In Ottawa, Diefenbaker once again spoke out against this new assault on Canadians. In a press release, which was somewhat more subdued in tone than that which followed the $\mathrm{N}^{\prime}$ djili incident, he acknowledged that he was "naturally gravely concerned that Canadian personnel are again encountering difficulties." He expressed the hope that the Congolese authorities would cooperate with the UN to ensure

203 Mendelsohn, 29 August 1960: D.Hist, 144.9.009 (D30); PFRMISNY to USSEA, 29 August 1960: N.A.C., RG25, Vol. 5209, File \$6386-40 pt. 10.2; "PM Protests Lalest Attack," Globe and Mail |Torontol 29 August 1960:1; Fred Gaffen, In the Eyp of the Storm: a History of Canadian Peacekeeping (Toronto: Deneau and Wayne Publishers I.td., 1987) 225-226. 
that there would be no further incidents.204 This second occurrence of serious violence did not shake the Globe and Mail's support for UNOC, in the least. This latest attack simply established the need for the UN to carry on its activities "for a long time to come."205

Ireland closely watched reactions to the $\mathrm{N}^{\prime}$ djili and Stanleyville incidents. There were two Irish battalions, totalling almost 1400 officers and men, stationed in the Congo and unlike the Canadians, Irish peacekeepers were there in a combat capacity. Sweden, Denmark and Norway also had white forces serving in UNOC. After $N^{\prime}$ djili, the UN representatives of Canada and these other countries began to meet informally to share confidential personal views of Congolese developments. They recognised that the reaction of any one government to incidents in the Congo could affect the position of the others, especially if withdrawal of an entire national contingent was contemplated. In turn, they each assured each other that their governments were not considering this possibility and noted Hammarskjöld's decision to stand firm against Lumumba's demand for the withdrawal of white forces. Charles Ritchie explained that Canadian opinion was in "complete support" of participation in UNOC, but that the recent ill treatment of Canadian peacekeepers "had caused indignation."206

Members of this group were anxious to understand the causes and implications of the violent actions of the soldiers in Lumumba's ANC. The Congolese government suggested that the attacks were simply a case of mistaken identity. White peacekeepers were confused with Belgian

204 External to PERMISNY, 27 August 1960: N.A.C., RG25, Vol. 5209, File \#6386-40 pt. 10.2 .

205 "Questions for the United Nations," Globe and Mail (Torontol 29 August 1960:6. 206 PERMISNY to External, 19 August 1960: N.A.C., RG25, Vol. 5209, File\#6386-40 pt. 10. 
paratroopers. Publicly, Ralph Bunche issued statements which supported this interpretation of events. He characterised the Congo as a society "in which suspicion leads to fear and fear easily leads to panic." 207 "Ye pointed to the mob that had mauled the Canadians in Stanleyville as an example of how the mere mention of paratroopers could set off a crowd, that would not otherwise be concerned with white peacekeepers. The Congolese were not generally 'anti-white'. They were 'anti-Belgian' and there was always the danger that one could be mistaken for the other.

In private, Bunche considered another plausible explanation. In a confidential report to New York, he said that incidents directed against white peacekeepers were "not accidental but were part of a pattern which might possibly be inspired deliberately by the Congolese government."208 The Secretary-General concurred with this view. While unwilling to say so publicly, Hammarskjöld was in fact convinced that the Stanleyville incident "came as a result of direct orders from Lumumba."209 Given the deteriorating relationship between the Secretary-General and the Prime Minister, this interpretation is quite plausible.

As the month of August wore on, Lumumba began to perceive the UN more and more as an obstacle to his political goals. He had increasingly turned to the Soviets for bilateral assistance once the American and Canadian governments had made it clear that assistance from the West would be made available only through UN channels. In addition, much to Lumumba's dismay, Hammarskjöld and the Security Council had so far refused to permit

207 PEMISNY to External, 2 September 1960: N.A.C., RG25, Vol. 5209, File \#6386-4n pt. 208 PERMISNY to External, 19 August 1960: N.A.C., RC25, Vol. 5209, File \#6386-10 pt. 10. 209 Cadieux, 27 August 1960: N.A.C., RG25, Vol. 5219, File $\$ 6386-C-40$ pt. 4. 
UNOC to assist the central government in its attempts to forcibly end the Katangese secession. By comparison, Lumumba's efforts to end the secession of South Kasai province, where independence had been declared by Albert Kalonji on August 8th, were very successful. He discovered that the Soviets were willing to transport ANC forces into Kasai. The ANC offensive ended the secession, but at a terrible human cost. The fighting took on tribal overtones, and Hammarskjold held Lumumba responsible for the resulting massacres. To Lumumba, the UN was becoming more of a hindrance than a help. By the end of August, he was calling not only for the Belgians to leave, but also the UN.210 He might have had a pretext if the peacekeepers fought back in either the Stanleyville or $N^{\prime}$ djili skirmishes. He may have also hoped that individual countries would withdraw their forces in response to the harassment and attacks.

The Soviet Union was quick to make good use of the N'djili and Stanleyville incidents. Soon after the Canadian Parliament approved participation in UNOC, Soviet officials delivered a memorandum to the Secretary-General. The document objected to the use of Canadian peacekeepers, given that Canada was one of Belgium's NATO allies. The Soviets argued that Canadian participation in UNOC was contrary to the Security Council's decision to "take all necessary resolution toward the speediest cessation of aggression, the immediate withdrawal of troops from the territory of the Republic of the Congo and respect for its territorial integrity and political independence." The memo called upon the Canadian government to "display due objectivity" by not sending forces to the 1960: 3.

210 "Lumumba Demands UN Follow Belgians Out." Globe and Mail|Torontol 27 August $.99-$ 
Congo.211 The Secretary-General, however, decided not to take the memorandum too seriously; he noted that even Kuznetsov, the Deputy Foreign Minister of the USSR, seemed to "ma!.e light of it."212

As relations between Lumumba and Hammarskjöld deteriorated during the remainder of August, the Soviets began to attack the SecretaryGeneral's actions. Canadian officials in New York noticed that "at times Soviet public criticism of Hammarskjold appears to follow closely the pattern of alternating praise and blame that Lumumba gives him."213 As countries in the West became increasingly suspicious of Lumumba, the Soviets provided him with bilateral assistance and moral support. From Yugoslavia, the Canadian Representative reported a conversation in which the Acting Head of the Yugoslav Foreign Ministry deplored the withdrawal of Lumumba's confidence from Hammarskjöld and placed blame for the crisis on past Belgian policies and the Russians "in equal measure." 214

Following the $N^{\prime}$ djili incident, the Soviets returned to the issue of Canadian participation in UNOC with a vengeance. The following passage appeared in Pravda on 21 August:

Contrary to the assurances given by the United Nations Secretary General Hammarskjoeld [sic], a detachment of the armed forces of Canada -- Belgium's ally in NATO -- landed in Leopoldville a few days ago, which aroused the fully justified indignation of the Congolese people and let to further aggravation of the tension in the country. 215

The day before, Kuznetsov held a press conference in New York and

211 PERMISNY to External, 8 August 1960: IN.A.C., RG25, Vol. 5219, File $\sharp 6386-C-40$ pt. 2.

212 Robertson to Green, 8 August 1960: N.A.C., RG25, Vol. 5219, File $\sharp 6386-C-40$ pt. 2. 213 PERMISNY to External, 15 August 1960: N.A.C., RG25, Vol. 5209, File $\$ 6386-40$ pt. 10.

214 BGRAD to External, 16 August 1960: N.A.C., RG25, Vol. 5209, File \$6386-40 pt. 10.

215 Moscow to External, 23 August 1960: N.A.C., RG25, Vol. 5209, File $\$ 6386-40$ pt. 10.2. 
demanded the withdrawal of "armed groups from Canada." The Soviet official no longer made light of Moscow's protests over Canadian participation. Instead, the inclusion of Canadians in UNOC turned into ammunition in what became, as the month wore on, a concerted Soviet attempt to discredit and undermine Hammarskjöld. The Secretary-General told Charles Ritchie that Kuznetsov "had taken the line that 'now you realize how unwise it was to send Canadian troops to the Congo' "216

During the Security Council session on 21 August, Kuznetsov once again raised the issue when he "vigorously attacked the inclusion of Canadians in the force" and demanded that they be withdrawn. He did not, however, take issue with Swedish participation, or the inclusion of troops from Denmark and Norway, even though the latter two countries are also members of NATO. Hammarskjöld defended his decision to enlist the help of Canada and showed "no sign of regretting or changing his position."217 He argued that of the 127 civilian experts in the Congo, 87 were from countries which, "by no stretch of the imagination," were connected with NATO and only 500 of the 18,000 UNOC peacekeepers were from NATO countries. Half of these would not have been required if Poland had been able to contribute the forces the UN had requested of them.218 In his address to the Council, the Congolese representative raised neither the issue of white forces generally, or Canadian participation in particular. Many other countries came to Canada's defence. Argentina, for example, considered the Soviet allegations against Canadian peacekeepers to be an insult to a country "whose international

216 Robertson to Diefenbaker, 22 August 1960: N.A.C., RG25, Vol. 5219, File $\sharp 6386-C-40$ pt. 3.

217 Robertson to Diefenbaker, 22 August 1960: N.A.C., RG25, Vol. 5219, File \#6386-C.-40 pt. 3.

218 Brian Urquhart, Hammarskjöld (New York: Alfred A. Knopf, 1972) 543. 
conduct had been universally recognised as serious, responsible and wor thy of respect." 219

Less than a week later, Kuznetsov "upbraidsd" Hammarskjöld again for continuing to use Canadian troops.220 This, combined with Soviet opposition to the decision to temporarily replace Ralph Bunche with another American, Andrew Cordier, raised tensions to yet a higher pitch. These criticisms persisted well into September, when the Soviets continued their campaign against Hammarskjold in the General Assembly. Charles Ritchie reported widespread concern at the UN for the Secretary-General's future with the organisation, given the strength and severity of the USSR's criticism. Diplomats wondered if the Soviets were "out for his scalp." 221 The Canadian diplomat thought it premature to conclude that the USSR was aiming for Hammarskjöld's resignation, but was concerned that the Congo crisis had clearly become an issue in the Cold War. The potential for intervention by one of the Great Powers in the internal affairs of the Congo seemed all the more likely, and this posed a far greater threat than the initial mutiny by the Force Publique and the subsequent Belgian intervention. In this context, Lumumba's threats to expel UN forces, if he carried through on them, would have presented a new dilemma. Because the departure of UNOC would have constituted a potential threat to international peace and security, the decision to withdraw UN forces could no longer be made "on a unilateral and arbitrary basis by the Congo government." 222 Such a decision would have to be deliberated in the Security Council. As early as 17 August, the Canadian

214 Robertson to Diefenbaker, 25 August 1960: N.A.C., RC;25, Vol. 5219, File $\# 6386-C-40$ pt. 3 .

220 Brian Urquhart, Hammarskjöld (New York: Alfred A. Knopf, 1972) 436-437.

221 PEMISNY to External, 15 September 1960: N.A.C., RG25, Vol. 5209, File $\$ 6386-40$ pt. 11.2.

222 Brian Urquhart, Hammarskjöld (New York: Alfred A. Knopf, 1972) 436-437. -102 - 
Cabinet was aware that a day might come when a decision on the withdrawal of the Canadian UNOC contingent would mean choosing between either the Congo Government's demands or the UN's wishes.223

The Soviet campaign against Hammarskjöld revealed the increasing impact of the cold war on the direction of the Congo crisis. Prior to independence, the Secretary-General hoped that preemptive technical assistance would be sufficient to prevent or minimise the difficulties of a transition from colony to nation. He hoped that Africa could be insulated from Cold War politics and superpower intervention if the UN stepped forward to provide transitional assistance. Once the Force Publique mutinied, however, the need for technical assistance was superseded by the more pressing challenge of restoring order. Dissatisfied with the UN's pace and unwillingness to cooperate with his own political objectives, Prime Minister Lumumba threatened to call upon, and then accepted, an increasing level of Soviet bilateral assistance.

Canadian diplomats noted this development with concern. One of Lumumba's influential advisors, Madame Blouin, was known to be a communist; Roger Bull aescr: id the Lumumba government's limitations on the freedom of the press as indicative of the "insidious growth" of her "communist methods for so-called patriotic ends." Bull did not think that many Congolese had "the foggiest idea of what communism is," but he hastened to add that if it could serve as "a stick to beat the Belgians or belabour unkind fate" they would not hesitate to use it.224 David Jornson, the Canadian Ambassador to Moscow, suggested that the Soviets were encouraging Lumumba to bypass the $\mathrm{UN}$, in favour of accepting assistance

223 Cabinet Conclusions, 17 August 1960: N.A.C., RG2, Vol. 2747.

224 Bull to Robertson, 19 August 1960: N.A.C., RC.25, Vol. 5209, File $\$ 6386-40$ pt. 10. 
from the military forces of Guinea and Ghana.225 The motives of the 'leftleaning' government of Guinea were considered highly suspect.

In addition, Canadian citizens wrote the Diefenbaker government to express similar concerns. J.R. Gregory conveyed his suspicions to Howard Green. He was worried about the use of Soviet military aid and technicians to fill the vacuums created by transitions in colonial status or changes in government. "In my opinion," he concluded, "the time to stop the Soviet is now. The method is assist with technical aid."226 G. Landreth urged Green to "keep a wary eye on men behind the principal actors such as Lumumba and Castro." He wondered just who Soviet technicians in the Congo were speaking to while Lumumba was on his North American tour and questioned whether or not the USSR was setting up the West for "another highjack game." 227 The "pattern" of Russian intervention in "countries all over the world" was the principle concern of V.M. McFaul. He was upset that the West was often "TOO LATE" to come to the realisation that communists instigated "bullying tactics, riots and threats" to achieve their aims. He suggested a nation and world-wide campaign to lay bare the "ugliness of communism in all its evil irtent." 228 While not every Canadian would have shared in the vehemence of these views, these letters demonstrate that the Congo crisis was perceived by the public in the context of the Cold War, much as it often was by officials at External Affairs.

By the middle of August, and on into September, the Diefenbaker government found itself in a difficult position because of a commitment it

225 Johnson to Green, 16 August 1960: N.A.C., RG25, Vol. 5209, File $\$ 6386-40$ pl. 10.

226 Gregory to Green, 21 July 1960: N.A.C., RG25, Vol. 5209, File\#6386-40 pt. 10.

227 Landreth to Green, 23 July 1960: N.A.C., RG25, Vol. 5209, File $\# 6386-40$ pl. 10.

228 McFaul to Diefenbaker, 11 August 1960: N.A.C., RG25, Vol. 5209, File \#6386-40 pt. 10. 
had made to send four Caribou aircraft to support Canadian peacekeepers serving with UNOC. On 1 August, the government announced in the House of Commons its intention to purchase these planes from the de Havilland Aircraft Company. Because of their ability to take off and land within short distances, they were considered ideal for conditions in the Congo.

Initially, the RCAF had used North Stars to transport the gift of Canadian food aid. The Cabinet subsequently approved a plan to use these aircraft in an airlift of UN supplies and equipme.t from Pisa, Italy to Leopoldville, for a period of thirty days. It will be recalled that a controversy developed when it was discovered that the North Stars were also used for internal transport of UN forces. The Cabinet strongly discouraged using the planes for this purpose. In any event, the North Stars were recalled to Canada, with the agreement of UN officials, to transport the Canadian signallers to the Congo. Once all Canadian forces had been airlifted, the North Stars were expected to return to duties on the Pisa-Leopoldville external airlift, leaving the new Caribou to primarily provide internal air support for Canadian forces in UNOC. When the needs of Canadian forces were met, the planes were then to be available for other UN duties.

Officials at External, however, expected that there might be difficulties in persuading the UN to accept the Caribous if they were to be "used in direct support of the Canadian Army, and were not to be placed generally at t'e disposal of the U.N. Commander or under the full operational control." 229 In effect, this interpretation of the Caribous' role would have required the Canadian government to negotiate a direct bilateral agreement with the Congo government, an arrangement which was not considered "practical to

229 Robertson to Green, 9 August 1960: N.A.C., RG25, Vol. 5219, File \$6386-C-40 pt. 2. $-105$. 
contemplate."230 Pearkes, however, felt that the government should adhere to the Cabinet's position. He noted that restrictions had been placed on the UN's use of the Canadian signallers (i.e. that they were not to be used in advance of Brigade or Regional Headquarters), and felt that in this vein the best policy would be to suggest a compromise, by which the RCAF Caribou unit would be "employed under the operational control of the United Nations Commander with priority begin given to Canadian force requirements."231

By mid-September, the Caribou problem was still not resolved. In fact, it became more complicated. Hammarskjöld had "responded negatively in very firm terms" to the compromise proposal suggested by the government. Given the criticism he had faced from the Soviets over his decision to include Canadian signallers in UNOC, he believed a proposal to send a Canadian air unit would leave him in an "untenable position." 232 Hammarskjöld suggested that the Caribou might still be used if Canada was prepared to make them available on a 'lend-lease' basis, so that they could be staffed by aircrews from other UN units. ${ }^{233}$ Col. Mendelsohn returned to Ottawa in September to give a preliminary report to the Department of National Defence. He argued that, in spite of the Secretary-General's concerns, there was an urgent need for the Caribou and tiat this need was fully recognised by von Horn. The only thing standing in the way was Hammarskjöld's desire not "to upset the Russians." 2.34

230 Robertson to Green, 9 August 1960: N.A.C., RG25, Vol. 5219, File\#6386-C-40 pt. 2.

2.31 Pearkes to Green, 11 August 1960: N.A.C., RG25, Vol. 5219, File \#6386-C-4` pt. 2.

232 Defence Liaison to Cadieux, 30 August 1960: N.A.C., RC25, Vol. 5219 , File $\$ 6.386-C-40$ pi 4.

233 Defence Liaison to Cadieux, 30 August 1960: N.A.C., RG25, Vol. 5219 , File \#6386-C-40 pt. 4.

234 Murray to Robertson, 14 September 1960: N.A.C., RG25, Vol. 5219, File \#6386-C-40 pt. 4. 
Apart from the difficulties that arose with the Caribous, the RCAF was of considerable assistance to the UN, especially in the early days of UNOC. A Canadian, Group Captain W.K. Carr, was in charge of administering internal air operations and by August RCAF strength reached fifty-eight peacekeepers.235 Together with technicians from the Canadian Department of Transport, the RCAF played an important role in directing air traffic, a task that had previously been performed by Belgian technicians who had left the Congo with the wave of European evacuees in the days following the mutiny of the Force Publique. In fact, a mere two hours before UNOC forces were scheduled to arrive at a rate of one troop transport every half hour, the only person in the control tower at N'djili airport was a "very drunk Belgian who was discovered collapsed over his instruments." 236 Overall, the RCAF flew 39: flights, transporting four million tons of freight and 11,746 passengers. 237

On 5 September, the fragile coalition between President Kasavubu and Prime Minister Lumumba fell apart. The President took it upon himself to fire the Prime Minister and this embroiled UNOC in a constitutional struggle. In the days before his announcement, Kasavubu consulted with Andrew Cordier, who was in the Congo temporarily leading the UN operation until Rajeshwar Dayal could replace Ralph Bunche. Kasavubu asked Cordier to arrest 25 people, provide protection for his residence and encouraged him to use peacekeepers to take control over the airport and radio. Cordier refused the first request, but in the days that immediately followed Kasavubu's announcement did use the UN force to secure the residences of all Congolese

235 Fred Gaffen, In the Eye of the Storm: a History of Canadian Peacekeeping (Toronto: Deneau and Wayne Publishers Ltd., 1987) 222-223.

236 Lincoln Bloomfield, "Headquarters-Field Relations: Some Notes on the Beginning and End of ONUC." International Organization 17 (1963): 383.

237 Fred Gaffen, in the Eye of the Storm: a History of Canadian Peacekeeping (Toronto: Deneau and Wayne Publishers Lid., 1987) 223. 
politicians who requested protection. In the belief that it would make it easier to maintain law and order, a key function of UNOC's mandate, Cordier also assumed control of the airport and radio station. By doing so, however, he inadvertently influenced the outcome of the constitutional struggle by "tilting the scales in favor of Kasavubu and against Lumumba."238 Because the airport was closed, Lumumba could not receive support from the outlying areas where he was most popular. By comparison, Kasavubu's support was "primarily in Leopoldville" and he alone had access to radio transmitters in Brazzaville.239

In spite of these political advantages, a joint session of the Congolese Chamber and Senate voted full powers to Lumumba on 13 September. To counter this, Kasavubu used his presidential authority to adjourn both legislative bodies the next day. The constitutional struggle then took a decisive turn when Col. Mobutu of the ANC mounted a military coup. He announced that he was acting to 'neutralise' both Lumumba and Kasavubu, the rival governments each had established, and parliament. He proposed the establishment of a College of Commissioners to run the Congo and ordered the withdrawal of all Communist diplomatic missions. Mobutu had been concerned about Lumumba's reliance on Russian, Ghanaian and Guinean advisors and the Prime Minister's strained relations with the UN.240 Mobutu was seen as more moderate than Lumumba. Often, he was the one who tried to "patch things up with the United Nations after Lumumba had made a

238 Herbert Nicholas, "UN Peace Forces and the Changing Clobe: the Lessons of Suez and the Congo," International Organization 17 (1963): 332.

239 Rosalyn Higgins, United Nations Peacekeeping, 1946-1967: Documents and Commentary 4 vols. (Oxford: Oxford U P, 1980) 3: 144.

240 Madeleine Kalb, The Congo Cables: The Cold War in Africa-From Eisenhower to. Kennedy (New York: Macmillan Publishing Co., Inc., 1982) 93. 
particularly outrageous statement."241 It was Mobutu who had apologised to Canada for the beatings of peacekeepers at $N^{\prime}$ djili airport, when Lumumba refused to do so at first. Soon after the coup, he reinstated Kasavubu, who in turn installed the coup leader's College of Commissioners. Belgian officials supported the new Kasavubu-Mobutu régime, but the UN continued to press for a reconciliation between Lumumba and Kasavubu.242

The Security Council convened to consider the new situation in the Congo from 14 to 17 September. When it failed to arrive at a decision, the General Assembly was called into an eme. rency session from 17 to 20 September. There, resolution 1474(ES-IV) was passed.243 It called on the Secretary-General to continue with the "vigorous" implementation of the previous Security Council resolutions. It also established a conciliation commission and a Congo fund, to which all UN members were urgently requested to make a financial contribution. Finally, it appealed to the Congolese to find a "speedy" solution to their internal conflict, by peaceful means and requested other nations to refrain from any action that might impede the restoration of peace. The Canadian government supported the resolution, asserting that it was essential to provide "the broadest possible measur: of support in furtherance of the UN efforts in the Congo to bring about stability and peace." 244

Following the initial weeks of UNOC's deployment and the Mobutu coup, the UN was required to take an increasingly aggressive course of action

241 Madeleine Kalb, The Congo Cables: The Cold War in Africa-From Eisenhower to Kennedy (New York: Macmillan Publishing Co., Inc., 1982) 93.

242 Wynfred Joshua, "Belgium's Role in the UN Peacekeeping Operation in the Congo," Orbis 11.2 (1967) 421.

243 General Assembly Resoiution 1474(ES-IV) is reproduced in Appendix 1.

244 PERMISNY to External, 19 September 1960: N.A.C., RG25, Vol. 5209, File \#6386-40 pt. 11.2 . 
to restore law and order and preserve the territorial integrity of the new country. But by mid-September, Canadian peacekeepers in UNOC were already pessimistic about UN chances for success. They suggested that behind the facade of "normalcy" in Leopoldville there was "a vacuum containing a number of potential volcanoes, any one of which could erupt suddenly to cause a major collapse of this 'house of cards" "245 The overall situation was seen as,

heavily overcast with clouds of demagogism, ignorance, suspicion and severe growing pains. The demagogues can bring utter chaos by embroiling the country and the UN in civil war. The ignorance of the leaders of the various governments invites opportunism and knavery with all the well-known consequences. The suspicious nature of the Congolese, due to their low standard of education, hinders full co-operation with the UN and 'whites' in whose hands the future development of the country must lie for some years to come. Both the Congo government and ONUC are having growing pains which no doctor other than time can cure. The great question is whether or not the other clouds will permit the doctor to complete his treatment.246

Colonel Mendelsohn provided the Department of National Defence and External Affairs with an equally pessimistic and disturbing account of the Canadian contingent's early experiences in UNOC. He was alarmed not only by political developments, but also by the way in which the UN military operation "was being conducted." 247 In particular, Mendelsohn was critical of von Horn. He attributed the Supreme Commander's lack of "firmness" to an inability to act without first receiving instructions from New York, or UN civilians in Leopoldville. The Canadians also felt that they were victims of discrimination, not only by the native Congolese, but also by the UN. He

245 Webb to AHQ 24 August 1960: N.A.C., RG24, Vol. 18,482, Folder 9.

246 Webb to AHQ 24 August 1960: N.A.C., RG24, Vol. 18,482, Folder 9.

247 Murray to Robertson, 14 September 1960: N.A.C., RG25, Vol. 5219, File $\$ 6386-C-40$ pt. 4. 
argued that African members of UNOC were given preference over peacekeepers from neutral and especially NATO countries. As the Commanding Officer of the Canadian Headquarters detachment, Mendelsohn was especially bitter about not being consulted by UN officials on the use of the signals squadron. He felt that the headquarters detachment was ignored by von Horn and his staff. It is difficult to know to what degree this coloured the colonel's perception of the usefulness of the Canadian contribution.248

Nevertheless, his account of these early days in UNOC left officials at External Affairs expecting "the Canadian Army to be rather cool to additional requests from the United Nations for military assistance in the Congo."249

248 Interestingly, von Horn in his memoirs acknowledges that the Canadian Signal Squadron virtually ran all of UNOC's communications. His statements which followed the assault on Canadian forces also suggested that he had a great deal of respect for the Canadian peactkeepers. Major General Carl von Horn, Soldiering for Peace (London: Cassell, 1966) 188. 249 Murray to Robertson, 14 September 1960: N.A.C., RG25, Vol. 5219, File\#6386-C-40 pt. 4. 


\section{Conclusion}

In spite of Colonel Mendelsohn's concerns, Canada continued to participate in UNOC until the final weeks before the UN mission ceased operations in 1964. There had been no 'speedy' solution to the civil sirife that plagued the Congo's transition from colony to nation. The limited literature on Canada's role in the United Nations Operation in the Congo has stressed public pressure as the key factor in the Diefenbaker government's decision to participate in LNOC. In the traditional reconstruction of events, Diefenbaker is shown, at first, to be reluctant to send peacekeepers. Once faced with mounting public pressure, however, the government "caved in," changed policy, and agreed to provide the UN with Canadian personnel. J.L. Granatstein argues that "the public's desire that Canada should serve the United Nations was so strong indeed that it could force the government's hand."250 Fred Gaffen concurs with Granatstein. In his account of UNOC., public opinion was a crucial factor in the decision to send Signallers. ${ }^{251} \mathrm{~A}$ review of the evidence, however, reveals two significant disparities with this interpretation of everts.

First, the Diefenbaker government's response to UN requests for assistance in the Congo was incremental. There was not an abrupt change in policy. Diefenbaker was indeed reluctant to assign peacekeepers to service in

250 J.L. Granatstein, "Canada and Peacekeeping: Image and Reality," Canadian Foreign Policy, Ed. J.L. Granatstein (Mississauga: Copp Clark Pitman, 1993): 279-280. This interpretation appears also in J.L. Granatstein, "Peacekeeping: Did Canada Make a Difference? And What Difference Did Peacekeeping Make to Canada," Making a difference? Eds. John English and Norman Hillmer (Toronto: Lester Publishing Limited, 1992): 229.

251 Fred Caffen, In the Eye of the Storm: a History of Canadian Peacekeeping (Toronto: Deneau \& Wayne, 1987) 219-220. 
UNOC. He was primarily concerned that Native Congolese might mistakenly identify Canadians as Belgians. Given the hostile feelings of the Congolese towards their former colonial administrators, the possibility of Canadian casualties was therefore high. Nevertheless, he agreed to the secondment to UNOC of Canadian officers already serving in UNTSO and UNEF. Because these peacekeepers were stationed in Leopoldville and would assist von Horn at UN headquarters, they did not play a combat role and so risk of personal injury was considered minimal.

Royal Canadian Air Force personnel were the next to be assigned to UNOC. North Star aircraft were used to transport the Canadian gift of food aid. Once these planes were in the area, the UN requested their use in an airlift of supplies between Pisa and Leopoldville. The Cabinet considered the request, and approved of this increased level of involvement in UNOC on the condition that the planes be used only in relatively safe tasks. Although the North Stars and their crews were eventually used occasionally for internal transport within the Congo, this was discouraged by the Canadian government. Their primary responsibility remained the external airlift to Leopoldville; later, they were used to transport signallers from Trenton to the Congo.

Hammarskjöld envisioned UNOC's development in two stages. In the first stage, only African and Asian forces would be used. The SecretaryGeneral did not intend to use peacekeepers from other countries until after the first group of contingents was deployed and had started to restore law and order. The government was nonetheless anxious because, beginning in 1958, they had earmarked a battalion of Canadian soldiers to be on standby for UN missions. They believed there was a possibility that Hammarskjöld might 
request these troops. Because the battalion could be required to fire on the Congolese in order to restore order, officials considered a combat role too dangerous for Canadians. They therefore warned the UN not to make such an appeal. There is no evidence, however, to suggest that the Secretary-General planned to call upon Canada to provide combat forces, even during the second stage of UNOC.

When the UN did finally request troops, it asked specifically for communications experts, especially those who were bilingual. Hammarskjold solicited Canada for non-combat forces, as he did with Norway and Denmark, which provided logistics support. All three countries were members of NATO. To include them in UNOC in a combat capacity would have been difficult to justify to the communist bloc. The Soviets did eventually attack the Secretary-General for his use of Canadians, but he was able to argue that they had been asked to serve in a non-combat capacity especially because of their technical and linguistic skills.

Once Diefenbaker learned that it was signallers, and not combat personnel that the UN sought, he was willing to entertain Hammarskjöld's appeal for further assistance. The smaller risk of casualties was a key factor in the decision to contribute signallers. The government believed it could further minimise the threat posed by violence if it placed restrictions on the deployment of signals personnel, to ensure that they could not be located in isolated and more dangerous locations. Diefenbaker did not change his views; at this time he still would not have supported the dispatch of the standby battalion's combat forces. The addition of signallers to the Canadian contribution to UNOC. was not a reversal in policy; rather, it was just another step in the progression of the government's support of UN efforts to resolve 
the Congo crisis. The Cabinet had first provided UNOC with headquarters staff, then air support and finally signallers.

The perception that the government was motivated to increase its participation in UNOC only as a result of the public's desire to serve the UN is the second significant inaccuracy in the traditional interpretation of Canadian peacekeeping in the Congo. Other factors, such as fear of communist intervention and the realisation by Canadian officials that the success or failure of UNOC had the potential to determine the future of the UN, were at least as important as the Canadian public's ambition to fulfil a peacekeeping role.

In chapter one, the possibility that the Canadian decision might have been made on the basis of economic interests in the Congo was ruled out. David Gibbs has suggested that business interests determined American policy in the Congo. The same can not be said for Canada. While trade between Canada and the Congo had increased substantially from 1926 to 1960, it was not a significant market for Canadian exports, relative to Canada's other trading partners. There was also very little Canadian investment in the area.

The first chapter did, however, reveal the roots of concern for communist influence in the Congo. While Canadian diplomats never fully agreed with Belgian assessments of communist penetration, they acknowledged that it was an issue and became more worried once the Force Publique mutinied. They did not accept the i tea that communists had inspired the mutiny and the subsequent political instabi.'ty, but they feared that the Soviet Union might take advantage of the chaos to establish a communist foot hold in Central Africa. Their anxiety later appeared justified 
by Lumumba's flirtations with the USSR and the intense criticism directed by the Soviets against the Secretary General's actions in the Congo. Speculation that communism might spread in the Congo, and from there to other African countries, was not confin \& to government officials; individual Canadians also expressed this view. Globe and Mail editorials on the Congo crisis assailed Soviet motives, as often as they prompted the Canadian government to fulfil a national obligation and responsibility to support UN peacekeeping.

The United Nations Operation in the Congo was a significant event in the history of the UN. It remains one of the largest peacekeeping forces ever assembled, requiring over 20,000 troops and logistical support from 30 countries.252 1,900 Canadians served in UNOC, and the government contributed $\$ 8$ million towards the mission's total cost of $\$ 400$ million.253 The Congo operation was significant, not just because of its size and cost, but also because of its wider implications for the future of the $\mathrm{UN}$ and the political development of Africa. The Secretary-General first considered the need for $\mathrm{UN}$ assistance in the Congo as a means to avoid superpower rivalry in Africa. Thus, it is ironic that UNOC became an irritant in Fast-IVest relations and, in the end, exacerbated Cold War tensions. One scholar has gone so far as to describe UNOC as the "unconscious midwife to the arrival of the Cold War in Africa." 254

As Hammarskjöld planned UNOC, it became increasingly clear to Canadian diplomats that a great deal would depend on its conduct and

252 J.L. Collins, "The Cold War Comes to Africa: Cordier and the 1960 Congo Crisis," Lournal of International Affairs 47.1 (1993) 244-245.

253 Fred Gaffen, In the Eye of the Storm: a History of Canadian Peacekeeping (Toronto: Deneau \& Wayne Publishers Ltd., 1987) 238 and J.L. Cranatstein, "Canada Peacekeeper," Peacekeeping: International Challenge and Canadian Response (1.ind say: Canadian Institute for International Affairs, 1968) 164'

254 J.L. Collins, "The Cold War Comes to Africa: Cordier and the 1960 Congo Crisis," Lournal of International Affairs 4i 1 (1593) 244-245. 
achievements. Although these implications were not necessarily clear to Canadian authorities in the initial days of the crisis, by the time an official UN request for signallers was received, the Under-Secretary of State for External Affairs was confident that Canada silould increase its commitment to the peace force, provided the government continued to take precautions to ensure that Canadian peacekeepers would not be unduly placed at risk. The Diefenbaker government undoubtedly felt public pressure to participate in UNOC, but in the past this factor has been given too much weight by historians who have explained the Canadian motivation to provide peacekeepers. A strong ciesire to see the UN succeed, especially when the Soviets appeared determined to see it fail, convinced Canadian authorities to continue their support, and indeed to increase it by sending the signals personnel the UN required. 


\section{Appendix 1}

\section{UN resolutions applicable to UNOC (July - September, 1960)}

\section{Security Council Resolution 143(1960): S/4387, 14 July 1960}

- adopted 8 votes to 0 , with 3 abstentions

The Security Council,

Considering the report of the Secretary-General on a request for United Nations action in relation to the Republic of the Congo,

Considering the request for military assistance addressed to the Secretary-General by the President and the Prime Minister of the Republic of the Congo (document S/4382),

1. Calls upon the Government of Belgium to withdraw their troops from the territory of the Republic of the Congo;

2. Decides to authorize the Secretary-General to take the necessary steps, in consultation with the Government of the Republic of the Congo, to provide the Government with such military assistance, as may be necessary, until, through the efforts of the Congolese Government with the technical assistance of the United Nations, the national security forces may be able, in the opinion of the Government, to meet fully their tasks;

3. Requests the Secretary-General to report to the Security Council as appropriate."

\section{Security Council Resolution 145(1960): S/4405, 22 July 1960}

- adopted unanimously on 22 July 1960

The Security Council,

Having considered the first report by the Secretary-General on the implementation of Security Council resolution S/ 4387 of 14 July 1960 (document S/4389),

Appreciating the work of the Secretary-General and the support so readily and so speedily given to him by all member States invited by him to give assistance,

Noting that as stated by the Secretary-General the arrival of the troops of the United Nations force in Leopoldville has already had a salutary effect,

Recognizing that an urgent need still exists to continue and to increase such efforts,

Considering that the complete restoration of law and order in the Republic of the Congo would effectively contribute to the maintenance of international peace and security.

Recognizing that the Security Council recommended the admission of the Republic of the Congo to membership in the United Nations as a unit,

1. Crlls upon the Government of Belgium to implement speedily the Security Council resolution of 14 July 1960, on the withdrawal of their troops, and authorizes the SecretaryGeneral to take all necessary action to this effect;

2. Requests all States to refrain from any action which might tend to impede the restoration of law and order and the exercise by the Government of the Congo of its authority and also to refrain from any action which might undermine the territorial integrity and the political independence of the Republic of the Congo; 
3. Commends the Secretary-General for the prompt action he has taken to carry out resolution S/ 4387 of the Security Council and his first report;

4. Invites the specialized agencies of the United Nations to render to the Secretarv. General such assistance as he may require;

5. Requests the Secretary-General to report further to the Security Council as appropriate.

\section{Security Council Resolution 146(1960): S/4426, 9 August 1960}

- adopted 9 votes to 0 , with 2 abstentions

The Security Council,

Recalling its resolution of 22 July 1960 (S/4405) inter alia, calling upon the Government of Belgium to implement speedily the Security Council resolution of 14 July (S/4387) on the withdrawal of their troops, and authorizing the Secretary-General to take all necessary action to this effect,

Having noted the second report by the Secretary-General on the implementation of the aforesaid two resolution and his statement before the Council,

Having considered the stateme.sts made by the representatives of Belgium and the Republic of the Congo to this Council at this meeting,

Noting uith satisfaction the progress made by the United Nations in carrying out the Security Council resolution in respect of the territory of the Republic of the Congo other than the the Province of Katanga,

Noting however that the United Nations had been prevented from implementing the aforesaid resolutions in the Province of Katanga although it was ready, and in fact attempted, to do so,

Recognizing that the withdrawal of Belgian troops from the Province of Katanga will be a positive contribution to and essential for the proper implementation of the Security Council resolutions,

1. Confirms the authority given to the Secretary-General by the Security Council resolutions of 14 July and 22 July 1960 and requests him to continue to carry out the responsibility placed on him thereby;

2. Calls upon the Government of Belgium to withdraw immediately its troops from the province of Katanga under speedy modalities determined by the Secretary-General and to assist in every possible way the implementation of the Council's resolutions;

3. Declares that the entry of the United Nations force into the Province of Katanga is necessary for the full implementation of this resolution;

4. Reaffirms that the United Nations force in the Congo will not be a party to or in any way intervene in or be used to influence the outcome of any internal conflict, constitutional or otherwise;

5. Calls upon all Member States, in accordance with Articles 25 and 49 of the Charter, to accept and carry out the decisions of the Security Council and to afford mutual assistance in carrying out measures decided upon by the Security Council;

6. Requests the Secretary-General to implement this resolution and to report further to the Security Council as appropriate. 


\section{General Assembly Resolution 1474 (ES-IV): A/4510, 20 September 1960}

- adopted 70 votes to 1 , with 11 abstentions

The General Assembly,

Having considered the situation in the Republic of the Congo,

Taking note of the resolutions of 14 and 22 July and of 9 August 1960 of the Security Council,

Taking into account the unsatisfactory economic and political conditions that continue in the Republic of the Congo,

Considering that, with a view to preserving the unity, territorial integrity and political independence of the Congo, to protecting and advancing the welfare of its people, and to safeguarding international peace, it is essential for the United Nations to continue to assist the Central Government of the Congo,

1. Fully supports the resolutions of 14 and 22 July and of 9 August of the Security Council,

2. Requests the Secretary-General to continue to take vigorous action in accordance with the terms of the aforesaid resolutions and to assist the Central Government of the Congo in the restoration and maintenance of law and order throughout the territory of the Republic of the Congo and to safeguard its unity, territorial integrity and political independence in the interests of international peace and security;

3. Appeals to all Congolese within the Republic of the Congo to seek a speedy solution by peaceful means of all their internal conflicts for the unity and integrity of the Congo, with the assistance, as appropriate, of Asian and African representatives appointed by the Advisory Committee on the Congo, in consultation with the Secretary-General, for the purpose of conciliation;

4. Appeals to all Member Governments for urgent voluntary contributions to a United nations Fund for the Congo to be used under United Nations control and in consultation with the Central Government for the purpose of rendering the fullest possible assistance to achieve the objective mentioned in the preamble;

5. Requests

(a) All States to refrain from any action which might tend to impede the restoration of law and order and the exercise by the Government of the Congo of its authority and also to refrain from any action which might undermine the unity, territorial integrity and political independence of the Republic of the Congo;

(b) Ali Member States, in accordance with Articles 25 and 49 of the Charter, to accept and carry out the decisions of the Security Council and to afford mutual assistance in carrying out measures decided upon by the Security Council;

6. Without prejudice to the sovereign rights of the Republic of the Congo, calls upon all states to refrain from the direct and indirect provision of arms or other material of war and mil y personnel and other assistance for military purposes in the Congo during, the ten: : orary period of military assistance through the United Nations, except upon the request of the United Nations through the Secretary-General tor carrying out the purposes of this resolution and of the resolutions of 14 and 22 July and of 9 August 1960 of the Security Council. 


\section{Bibliography}

\section{Primary Sources}

\section{1) Government Documents}

National Arc. ives of Canada

- RG2 - Records of the Cabinet

- RG20 - Records of Trade and Commerce

- RG24 - Records of the Department of National Defence

- RG25 - Records of External Affairs

Directorate of History, Department of National Defence

- various records relating to peacekeeping in the Congo

House of Commons, Canada. Hansard.

- "Congo-Action to Protect or Evacuate Canadian Citizens." July 11, 1960. p. 6018.

- "Congo-Availability of Canadian Contingent for Police Force." July 12, 1960. p. 6101.

- "Congo-Availability of Canadian Technical and Professional Personnel." July 13, 1960. p. 6179-80.

- "Congo-Action to Protect or Evacuate Canadian Citizens." July 13, 1960. p. 6181-82.

- "Congc-Statement Respecting Current Situation." July 14, 1960. p. 6272-74.

- "Supply-External Affairs." July 14-15, 1960. p. 6296-6371.

- "Congo-Supplementary Statement Respecting Current Situation." July 18, 1960.

p. 6408-9.

- "Congo-Statement Respecting Request for Recognition of Katanga Province." July 19. 1960. p. 6487.

- "Congo-Inquiry as to Sending of Canadian Forces." July 20, 1960. p. 6560.

- "Congo-Inquiry as to Sending of Canadian Forces." July 22, 1960. p. 6736-37.

- "Congo-Inquiry as to Sending of Canadian Forces." July 25, 1960. p. 6880-81.

- "Congo-Reported Firing on R.C.A.F. Plane." July 26, 1960. p. 6947-48.

- "Congo-Reported Need for Medical Assistance." July 26, 1960. p. 6948.

- "Congo-Seconding of Canadian Officers to UNEF." July 26, 1960. p. 6948-49

- "Congo-Inquiry as to Invitation to Prime Minister to Visit Canada." July 27, 1960.

p. 7022.

- "Congo-Suggested Offer of Canadian French Speaking Infantry Battalion." July 29, 1960. p. 7188.

- "Congo-Announcement of Provision of Canadian Signals Personnel and Equipment." July 30, 1960. p. 7263-64.

- "Congo-Suggested Offer of Canadian Infantry Battalion." July 30, 1960. p. 7264.

- "Congo-Reported Need for Medical Assistance." July 30, 1960. p. 7264.

- "Congo-Participation of Canadian Forces in Current Operations." August 1, 1960.

p. 7327-49.

- "Congo-Request for Statement on Canadian Assistance." August 3, 1960. p. 7456.

- "Congo-Bilingual Ability of Senior Canadian Officers." August 4, 1960. p. 7534.

- "Congo-Inquiry as to Application of Order in Council Respecting Troops." August 6, 1960. p. 7678.

- "Congo-Request for Statement on Present Situation." August 8, 1960. p. 7747-48. 
Senate, Canada. Hansard.

- "The Congo - Approval of participation of Canadian forces in United Nations Operations."

August 2, 1960.

2) Contemporary Newspaper and Periodical Literature

"Artificial Respiration." The Globe and Mail [Toronto] 1 August 1960: 6.

"Battle Congo Rebels." The Globe and Mail [Toronto] 11 July 1960: 1,2.

"Be Cautious on Congo, Canadian Investors Say." The Financial Post [Toronto] 30 July 1960: 12.

"Belgian Congo Corporation Establishes Buying Office in Canada." Commercial Intelligence Journal 65.1969 (1941): 498.

"Belgian Congo is Fertile Field for Canadian Manufactures." Commercial Intelligence Journal 75 (1946): 735-736.

"Belgian Congo Prepares Extensive Economic Program, but Declines Direct Assistance." Foreign Trade 5 (1949): 639-640.

"Belgian Congo: Speed Up Development." The Financial Post [Toronto] 15 August 1959: 30.

"Canada and the Congo Situation." External Affairs 13.5 (1961): 160-8.

"Canaaa Keeps Close Watch." Globe and Mail [Toronto] 12 July 1960: 1.

"Canada Congo Troops Prepare In Kingston for Assignment." The Globe and Mail [Toronto] 3 August 1960: 13.

"Canada Keeps Close Watch." The Globe and Mail [Toronto] 12 July 1960: 1.

"Canada Runs Airlift Job For Congo." The Globe and Mail [Toronto] 3 Aug. 1960: 1.

"Canada Set To Provide Food, Planes." The Globe and Mail [Toronto] 15 July 1960: 1.

"Canada to Aid Congo Only if UN in Charge." The Globe and Mail [Toronto] 13 July 1960: 1. 
“Canada's Defense Duty." The Globe and Mail [Toronto] 14 July 1960: 6.

"Canadian Troops in the Congo." External Affairs 13.6 (1961): 237-8.

"Canadians in the Congo." External Affairs 13.3 (1961): 111-12.

"Canadians in the Congo." External Affairs 16.12 (1964): 625-6.

"Canadians in UN Congo Force." External Affairs 16.7 (1964): 341.

"Chaos in the Congo." Canadian Labour 5.9 (1960): 36-7.

"Commonwealth Breakup Feared." The Globe and Mail [Toronto] 16 July 1960: 28.

"The Congo: Land of Wild Splendor, Hidden Riches." The Financial Post [Toronto] 22 May 1954: B7.

"Congo Refugee Influx Arouses Resentment Among East Africans." The Globe and Mail [Toronto] 19 July 1960: 3.

"Congo's Premier Asks Assistance From Ottawa." The Globe and Mail [Toronto] 30 July 1960: 1.

"Congo Premier Wins Pledge of U.S. Aid; Expected Friday." The Globe and Mail [Toronto] 28 July 1960: 8.

"The Cost of Keeping the Peace." External Affairs 15.3 (1963): 125-138.

"Defense, a Positive Policy." The Globe and Mail [Toronto] 30 July 1960: 6.

"Diefenbaker Alters View on Gravity of Incidents." The Globe and Mail [Toronto] 18 August 1960: 1.

“Financing UN Peace-Keeping Operations." External Affairs 15.7 (1963): 277-8.

"Four Members Quit Lumumba Cabinet." The Globe and Mail [Toronto] 18 July 1960: 1.

"Hands Off Katanga, Brussels Tells UN." The Globe and Mail [Toronto] 28 July 1960: 1.

"Inga Power: Fabulous Potential." The Financial Post [Toronto] 17 August 1957: 25 . 
"Jungle Giant: New Horizons for New Industry." The Financial Post [Toronto] 17 August 1957: 25.

"Keep Touch With Congo, Canada Told." The Globe and Mail [Toronto] 16 July 1960: 28.

“Keeping the Peace." External Affairs 16.6 (1964): 240-253.

"Looking for Signallers." The Globe and Mail [Toronto] 25 July 1960: 6.

"Loss of Signallers Called Blow to CD." The Globe and Mail [Toronto] 2 August 1960: 1.

"Lumumba Demands UN Follow Belgians Out." The Globe and Mail [Toronto] 27 August 1960: 3.

"Mr. K. Brinksman." The Globe and Mail [Toronto] 16 July 1960: 6.

"Polish Ship Hauls Arms to Africa." The Globe and Mail [Toronto] 18 July 1960: 1.

"Problem of the Congo." External Affairs 12.8 (1960): 754-6.

"Questions for the United Nations." The Globe and Mail [Toronto] 29 August 1960: 6 .

“Soviet Berates Katanga Chief." The Globe and Mail [Toronto] 19 July 1960: 3.

"Soviet Issues Warning." The Globe and Mail [Toronto] 16 July 1960: 1.

"Spotlight on Africa." The Globe and Mail [Toronto] 2 July 1960: 6.

"A Time for Coolness." The Globe and Mail [Toronto] 19 August 1960: 6.

"Toronto Major On Congo Staff." The Globe and Mail [Toronto] 19 July 1960: 3.

"UN Asks Canada Send Supply Unit to Congo." 'The Globe and Mail [Toronto] 26 July 1960: 1.

"UN to Send Team." The Globe and Mail [Torontol 13 July 1960: 2.

"UN Troops at Airport Get Orders to Shoot." The Globe and Mail [Toronto] 19 August 1960: 1. 
"UN Troops to Katanga." The Globe and Mail [Toronto] 26 July 1960: 6.

"Unconditional Aid to the Congo." External Affairs 12.10 (1960): 802-6.

"The United Nations and the Congo." The Globe and Mail [Toronto] 15 July 1960: 6.

"They Look to Canada." The Globe and Mail [Toronto] 2 August 1960: 6.

"Where Are the UN Police?" The Globe and Mail [Toronto] 12 July 1960: 6.

“Who Will Run the Congo?" The Globe and Mail [Toronto] 19 July 1960: 6.

"Whites Mob Lumumba, Punch Face." The Globe and Mail [Toronto] July 15, 1960: 1 .

"Will Send Signallers, PM Tells Lumumba." The Globe and Mail [Toronto] 1 August 1960: 1.

"Withdrawal of Canadian Contingent from the Congo." External Affairs 16.9 (1964): 449-50.

“Withdrawal of UN Troops from the Congo." External Affairs 15.8 (1963): 309.

Allen, Ralph. "Is Africa the Graveyard of the UN?" Maclean's 74 (17 June 1961): 52-3.

Allen, Ralph. "The Most Appalling Jungle War of all-the Handcuffed Fight Against Disease." Maclean's 74 (17 June 1961): 12, 54-6.

Allen, Ralph. "A Reporter at Large Among the Congolese Meets the Évolués-and Recent Cannibals." Maclean's 74 (17 June 1961): 13, 57-9.

Ausman, L.H. "Belgian Congo Being Explored as Confederation Came to Canada." Foreign Trade 4 (1948): 172-174.

Ausman, L.H. "Belgian Congo Economy Little Affected by General Devaluation of Currencies." Foreign Trade 8 (1950): 464-465.

Ausman, L.H. "Belgian Congo Enjoyed Favourable Economic Conditions Last Year." Foreign Trade 8 (1950): 267-273.

Ausman, L.H. "Belgian Congo Industrialization is Dependent on Four Factors." Foreign Trade 8 (1950): 417-421. 
Ausman, L.H. "Belgian Congo Prepared to Buy More Products from Canada." Foreign Trade 2 (1947): 646-649.

Ausman, L.H. "Belgian Congo Produces Primary Materials Needed by Industry." Foreign Trade 4 (1948): 455-460.

Ausman, L.H. "Canada Achieving Importance as Supplier to Belgian Congo." Foreign Trade 5 (1949): 1262-1267.

Ausman, L.H. "Canada-Belgian Congo Trade Can be Expanded Further." Foreign Trade 1 (1947): 217.

Ausman, L.H. "Development of the Belgian Congo to Stabilize Internal Economy." Foreign Trade 8 (1950): 630-632.

Ausman, L.H. “Leopoldville, Belgian Congo." Foreign Trade 1 (1947): 14-16.

Ausman, L.H. "Main Portion of Belgian Congo's Trade is Routed Through the Port of Matadi." Foreign Trade 5 (1949): 502.

Ausman, L.H. "Major Demand of Belgian Congo Market is Native Trade Goods." Foreign Trade 4 (1948): 363-366.

Ausman, L.H. "Much Accomplished in Belgian Congo." Foreign Trade 2 (1947): 559-560.

Ausman, i.H. "Resources of the Belgian Congo Include Forests and Minerals." Foreign Trade 4 (1948): 314-319.

Ausman, L.H. "Secondary Industries of Belgian Congo Stimulate Development." Foreign Trade 6 (1949): 154-158.

Ausman, L.H. "Trade Between Belgian Congo and Canada Multiplied During War." Foreign Trade 4 (1948): 66-69.

Bélanger, Maurice. "The Belgian Congo as a Market: Foreign Trade in 1936." Commercial Intelligence Journal 57.1760 (1937): 720-724.

Bélanger, Maurice. "The Belgian Congo as a Market: General." Commerical Intelligence Journal 57.1759 (1937): 657-662.

Bélanger, Maurice. "Canadian Trade Opportunities in the Belgian Congo." Commerical Intelligence Journal 62.1886 (1940): 452-453. 
Bélanger, Maurice. "Indent Trade in Belgium and the Belgian Congo." Commercial Intelligence Journal 54.1680 (1936): 658-659.

Bélanger, Ma' rice. "Trade of the Belgian Congo in 1935." Commercial Intelligence Journal 55.1708 (1936): 787-789.

Bélanger, Maurice. "Trade of the Belgian Congo in 1938." Commercial Intelligence Journal 61.1859 (1939): 559-561.

Britton, J.C. "Economic Conditions in the Belgian Congo." Commercial Intelligence Journal 64.1928 (1941): 36-38.

Britton, J.C. "Opportunities for Canadian Sales in the Belgian Congo." Commercial Intelligence Journal 64.1927 (1941): 8-11.

Britton, J.C. "Trading with the Belgian Congo." Commercial Intelligence lournal 64.1927 (1941): 11-16.

Brodie, A.B. "Assessing the Congo's Trade." Foreign Trade 104 (1955): 13-15.

Brodie, A.B. "Belgian Congo." Foreign Trade 14 (1954): 4-6.

Brodie, A.B. "Belgian Congo: Business Picks Up." Foreign Trade 102 (1954): 15-16.

Brodie, A.B. “Congo Goods for Congo Consumers." Foreign Trade 104 (1955): 36.

Brodie, A.B. "Development of Belgian Congo Provided in Ten-year Plan." Foreign Trade 7 (1950): 262-268.

Bull, R.A. "The Congo Meets Trading Problems." Foreign Trade 112 (1959): 2-5.

Bull, Roger. "How's Business in the Congo?" Foreign Trade 115 (1961): 12-14

Campeau, L.A. "The Belgian Congo Fears a Slump." Foreign Trade 11 (1952): 749-750.

Campeau, L.A. "The Congo Has Its Problems." Foreign Trade 12 (1952): 14.

Clay, George. "Entire Cabinet of the Congo Lacks Single Day's Experience." The Globe and Mail [Toronto] 30 June 1960: 7 
Feron, James. "Belgium Asks UN Probe Atrocities." The Globe and Mail [Toronto] 18 July 1960: 1.

Gall, Henderson. "Debt Plagues Congo: New Administration Faced with Collapse." The Globe and Mail [Toronto] 18 July 1960: 1.

Gibson-Smith, W. "Belgian Congo and Its Trade." Foreign Trade 12 (1952): 3-5.

Gibson-Smith, W. "Belgian Congo Develops Electric Power and Expands Secondary Industries." Foreign Trade 9 (1951): 686.

Gibson-Smith, W. "Belgian Congo Imports From Canada Showed Decided Increase Last Year." Foreign Trade 11 (1952): 145-146.

Gibson-Smith, W. "Business in the Belgian Congo." Foreign Trade 14 (1953): 17-19.

Gibson-Smith, W. "Finances of the Belgian Congo Were Buoyant in Pat Year." Foreign Trade 9 (1951): 842-843.

Gibson-Smith, W. "Increased Industrialization Causes Labour Shortage in Belgian Congo." Foreign Trade 9 (1951): 802-803.

Gibson-Smith, W. "Mining of Copper is Important to Belgian Congo Economy." Foreign Trade 9 (1951): 601-604.

Gibson-Smith, W. "Transport Development is Major Problem in the Belgian Congo." Foreign Trade 9 (1951): 726-727.

Gibson-Smith, W. "Value of Belgian Congo Exports Rose Strikingly in rast Year." Foreign Trade 9 (1951): 507-511.

Gilroy, Harry. "All Belgians to Quit Lower Congo Region." The Globe and Mail [Toronto] 19 July 1960: 3.

Gray, Walter. "Food Planes May Fly Refugees From Congo." The Globe and Mail [Toronto] July 19, 1960: 1.

Gray, Walter. "Emergency Pork, Milk Supply Sent." The Globe and Mail [Toronto] 18 July 1960: 1.

Holmes, John. "Trouble in the Congo gives United Nations another opportunity for effective action." Canadian Business 33.10 (1960): 152-156. 
Hoppener, Henk. "Be Cautious on Congo, Canadian Investors Say." The Financial Post [Toronto] 30 July 1960: 12.

Jaenen, C.J. "Chaos in the Congo." Canadian Commentator 4.12 (1960): 19-21.

Joesten, Joachim. "Africa Today: Caesarean Birth in the Congo." Saturday Night 75 (6 August 1960): 13-15.

Nesbitt, Wallace B. "The Situation in the Congo." United Nations General Assembly, April 4, 1961. S/S-61/4.

Nyenhuis, K. "Belgian Congo." Foreign Trade 113 (1960): 12-14.

Nyenhuis, K. “Congo's Industry Moves Ahead.” Foreign Trade 110 (1958): 13.

Nyenhuis, K. "What the Congo is Buying." Foreign Trade 107 (1957): 32-33.

Pratt, R.C. "African States and the Congo." The Canadian Forum 40.477 (1960): 147.

Pratt, R.C. "The African States, the U.N. and the Congo." The Canadian Forum 40.482 (1961): 269-70.

Pratt, R.C. "U.N. Dilemma in the Congo." The Canadian Forum 40.476 (1960): 125.

Smith, W. Gibson. "New Industries Open in the Belgian Congo." Foreign Trade 11 (1952): 212.

Stevens, G.R. "Trade of the African Sub-Continent: Central African GroupBelgian Congo \& Angola." Commercial Intelligence Journal 37.1247 (1927): 887-892.

Stevens, G.R. "Trade of the African Sub-Continent: Communications." Commercial Intelligence lournal 36.1217 (1927): 634-639.

Stevens, G.R. "Trade of the African Sub-Continent: Customs, Tariffs." Commercial Intelligence Journal 36.1220 (1927): 735-739.

Stevens, G.R. "Trade of the African Sub-Continent: Distribution Systems." Commercial Intelligence Journal 36.1218 (1927): 667-670.

Stevens, G.R. "Trade of the African Sub-Continent: General, Production \& Natural Resources." Commercial Intelligence Journal 36.1216 (1927): 593-598. 
Sutton, Thomas A. "The Record of Haut Katanga." The Globe and Mail [Toronto] 25 July 1960: 6.

Tanner, Henry. "First UN Peace Troops Reach Congo." The Globe and Mail [Toronto] 16 July 1960: 1 .

Tanner, Henry. "Ultimatum Delivered to Chief of Forces." The Globe and Mail [Toronto] 18 July 1960: 1.

Turcot, Henri. "The Situation in the Belgian Congo." Commercial Intelligence Journal 46.1462 (1932): 161-162.

Worthington, "The Human Side of the Congo." Saturday Night 75 (24 December 1960): 12-13.

3) Memoires and Biographies

Dayal, Rajeshwar. Mission for Hammarskjold: the Congo Crisis. Princeton: Princeton U P, 1976.

Diefenbaker, John G. One Canada. 3 vols. Toronto: Macmillan of Canada, $1975,1976,1977$.

O'Brien, Conor Cruise. To Katanga and Back. New York: Grosset \& Dunlap, 1962.

Urquhart, Brian Hammarskjold. New York: Alfred A. Knopf, 1972.

von I Iorn. Maj. Gen. Carl. Soldiering for Peace. London: Cassell, 1966.

\section{Secondary Sources}

Abi-Saab, Georges. The United Nations Operation in the Congo 1960-1964. Oxford: Oxford U P, 1978.

Anglin, Douglas G. "Towards a Canadian Policy on Africa." International Lournal 15 (Autumn 1960): 290-310.

Bloomfield, Lincoln P. "Headquarters Field Relations: Some Notes on the Beginning and End of ONUC.." International Organization 17 (1963): 376-389. 
Bowman, Edward H. and James E. Fanning. "The Logistics Problems of a UN Military Force." International Organization 17 (1963): 355-376.

Burns, Arthur Lee \& Nina Heathcote. Peacekeeping by U.N. Forces. London: Pall Mall Press, 1963.

Collins, Carole. "The Cold War Comes to Africa: Cordier and the 1960 Congo Crisis." Lournal of International Affairs 47.1 (1993): 243-269.

Collins, Carole. "Fatally Flawed Mediation: Cordier and the Congo Crisis of 1960." Afric: Today 39.3 (1992): 5-22.

Gaffen, Fred. In the Eye of the Storm: a History of Canadian Peacekeeping. Toronto: Deneau \& Wayne, 1987.

Gibbs, David N. "Dag Hammarskjold, the United Nations, and the Congo Crisis of 1960-1: a reinterpretation." The Journal of Modern African Studies 31.1 (1993): 163-174.

Gibbs, David N. The Political Economy of Third World Intervention. Chicago: U of Chicago P, 1991.

Gordon, J. King. The United Nations in the Congo. Carnegie Endowment for International Peace, 1962.

Gordon, J. King. "Prospects for Peacekeeping." International Journal 25.2 (1970): 370-387.

Granatstein, J.L. “Canada: Peacekeeper, A Survey of Canada's Participation in Peacekeeping Operations." Peacekeeping: International Challenge and Canadian Response. Lindsay: Canadian Institute for International Relations, 1968. 93-187.

Granatstein, J.L. "Canada and Peacekeeping: Myth and Reality." The Canadian Forum 54.263 (1974): 14"19.

Granatstein, J.L. "Peacekeeping: Did Canada Make a Difference? And What Difference Did Peacekeeping Make to Canada?" Making a Difference? Ed. John English and Norman Hillmer. Toronto: Lester Publishing Limited, 1992. 222-2.36.

Hennessy, M.N. Congo: A Brief History and Appraisal. London: Pall Mall Press, 1961. 
Higgins, Rosalyn. United Nations Peacekeeping 1946-1967. Vol. III. Oxford: Oxford U P, 1980.

Holmes, John. "The United Nations in the Congo." International Journal 16.1 (1960-61): 1-16.

Hoskyns, Catherine. The Congo Since Independence: January 1960-December 1961. London: Oxford U P, 1965.

House, Arthur H. The U.N. in the Congo: The Political and Civilian Efforts. Washington, D.C.: U P of America, 1978.

Joshua, Wynfred. "Belgium's Role in the UN Peace-keeping Operation in the Congo." Orbis 11.2 (1967): 414-439.

Kalb, Madeleine. The Congo Cables. New York: MacMillan Publishing Co., Inc., 1982.

Kitchen, Helen. Footnotes to the Congo Story. New York: Walker and Company, 1967.

Lefever, Ernest W. Crisis in the Congo. Washington D.C.: The Brockings Institution, 1965.

L.efever, Ernest W. "The Limits of UN Intervention in the Third World." The Review of Politics 30.1 (1968): 3-19.

Martelli, George. Leopold to Lumumba. London: Chapman \& Hall L.td., 1962.

Matthews, Robert O. "Africa in Canadian Affairs." International Iournal 26 (Winter 1970-71) 122-50.

Merriam, Alan P. Congo: Background to Conflict. Illinois: Northwestern U P, 1961.

Nicholas, Herbert. "UN Peace Forces and the Changing Globe: Lessons of Suez and Congo." International Organization 17 (1963): 321-327.

Robinson, Basil. Diefenbaker's World: A Populist in Foreign Affairs. Toronto: U of Toronto P, 1989.

Rikhye, Indar Jit. "Peacekeeping and Peacemaking." Peacekeeping: Appraisals and Proposals. Ed. Henry Wiseman. Toronto: Pergamon Press, 1983.

Schatzberg, Michael G. Mobuto ur Chaos? New York: U P of America, 1991. 
Simmonds, R. Legal Problems Arising from the United Nations Operations in the Congo. The Hague: Martinus Nijhoff, 1968.

Streulens, Michel. The United Nations in the Congo or O.N.U.C. and International Politics. Brussels: Max Arnold, 1976.

United Nations. The Blue Helmets. 2nd ed. New York: United Nations Department of Public Information, 1990.

Urquhart, Brian. "Untied Nations Peace Forces and the Changing United Nations: an Institutional Perspective." International Organization 17 (1963): 338-354.

Wainhouse, David W. International Peace Observation. Baltimore: The Johns Hopkins Press, 1966.

Weissman, Stephen R. American Foreign Policy in the Congo 1960-1964. Ithaca: Cornell U P, 1974.

Wiseman, Henry. "United Nations Peacekeeping: An Historical Overview." Peacekeeping: Appraisals and Proposals. Ed. Henry Wiseman. Toronto: Pergamon Press, 1983. 

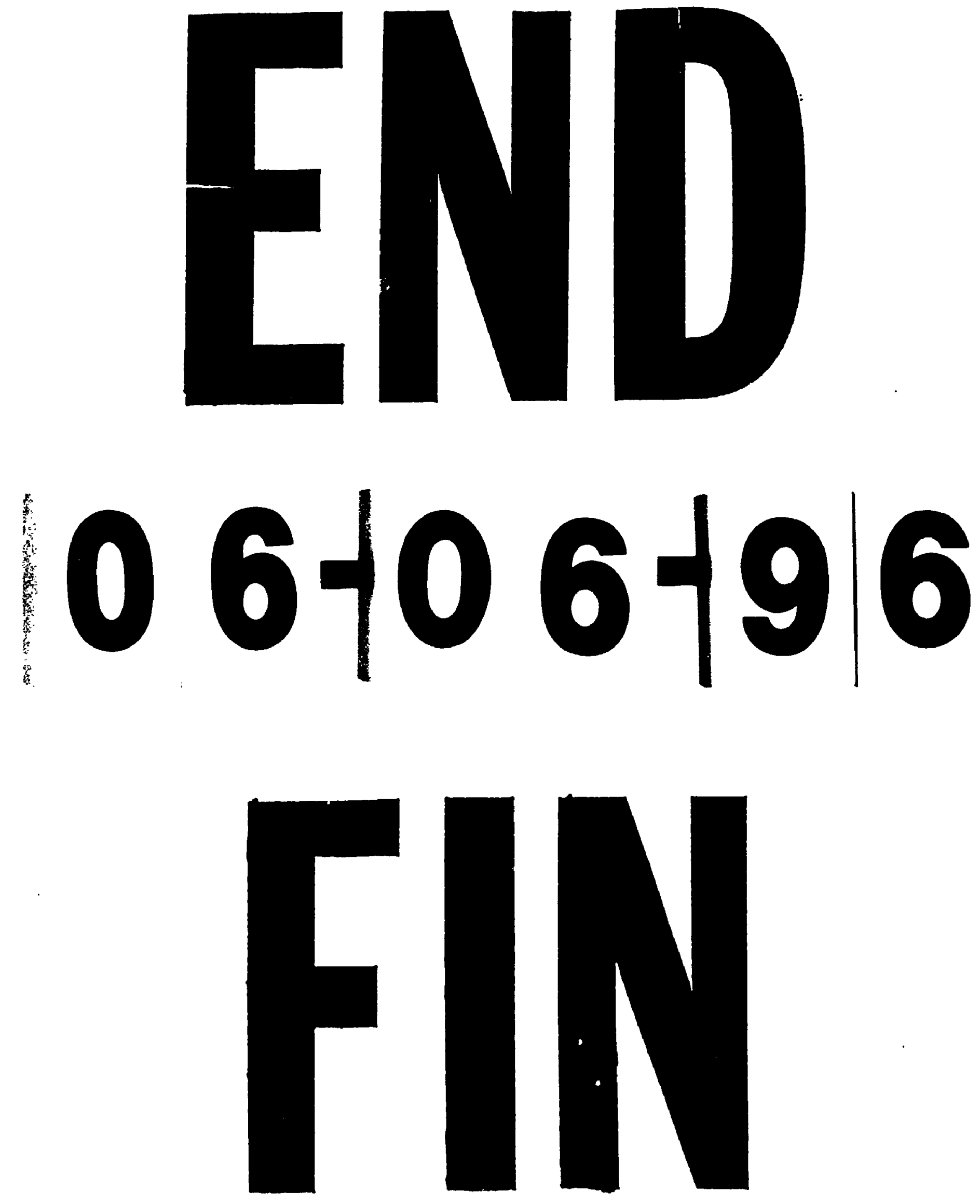